\title{
Radiofrequency catheter ablation for atrial flutter and atrial fibrillation : new insights
}

Citation for published version (APA):

Nabar, A. A. (1999). Radiofrequency catheter ablation for atrial flutter and atrial fibrillation : new insights. [Doctoral Thesis, Maastricht University]. Universiteit Maastricht. https://doi.org/10.26481/dis.19991216an

Document status and date:

Published: 01/01/1999

DOI:

10.26481/dis.19991216an

Document Version:

Publisher's PDF, also known as Version of record

\section{Please check the document version of this publication:}

- A submitted manuscript is the version of the article upon submission and before peer-review. There can be important differences between the submitted version and the official published version of record.

People interested in the research are advised to contact the author for the final version of the publication, or visit the DOI to the publisher's website.

- The final author version and the galley proof are versions of the publication after peer review.

- The final published version features the final layout of the paper including the volume, issue and page numbers.

Link to publication

\footnotetext{
General rights rights.

- You may freely distribute the URL identifying the publication in the public portal. please follow below link for the End User Agreement:

www.umlib.nl/taverne-license

Take down policy

If you believe that this document breaches copyright please contact us at:

repository@maastrichtuniversity.nl

providing details and we will investigate your claim.
}

Copyright and moral rights for the publications made accessible in the public portal are retained by the authors and/or other copyright owners and it is a condition of accessing publications that users recognise and abide by the legal requirements associated with these

- Users may download and print one copy of any publication from the public portal for the purpose of private study or research.

- You may not further distribute the material or use it for any profit-making activity or commercial gain

If the publication is distributed under the terms of Article $25 \mathrm{fa}$ of the Dutch Copyright Act, indicated by the "Taverne" license above, 
Radiofrequency catheter ablation for atrial flutter and atrial fibrillation

new insights 
(C) Ashish Ashok Nabar, Mastricht 1999

ISBN 9052782660

Comer page derighed by"

Geertjan van Zonneveld

Picture on the back coverpage:

Top: Academisch Ziekenhus Mastricht, Maastricht.

(Audiovisuele Dienst, AZM)

Botrom: Cardiovascular and Thoracic Center. KEM Hospital, Mumbai.

(Courtesy of Dr Amit Vora)

Layont and printing.

Datawyse | Universitaire Pers Maastricht 


\title{
Radiofrequency catheter ablation for atrial flutter and atrial fibrillation new insights
}

\author{
PROEFSCHRIFT
}

ter verkrijging van de graad van doctor aan de Universiteit Maastricht, op gezag van de Rector Magnificus, Prof. dr. A.C. Nieuwenhuijzen Kruseman. volgens het besluit van het College van Decanen, in het openbaar te verdedigen op donderdag 16 december 1999 om 10.00 uur door

\section{Ashish Ashok Nabar}

geboren te Mumbai, India

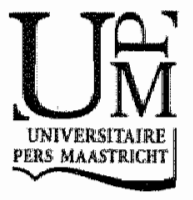




\section{Promotor}

Prof. dr. H.J.J. Wellens

\section{Co-promotor}

Dr. Luz-Maria Rodriguez

\section{Beoordelingscommissie}

Prof dr. M.A. Allessic (voorzitter)

Prof. dr. H.J.G.M. Crijns (Rijksuniversiteit Groningen)

Prof. dr. J. Farré (Universidad Autónoma de Madrid, Spain)

Prof dr. R.S. Reneman

Dr. M.A.Vos

Financial support by Dr. Osypka GmbH., Bakken Research Center B.V., Bard Benelux N.V and Biosense-Webster, Belgium for the publication of this thesis is gratefully acknowledged. 


\section{Lasmäd asaktah satatum \\ Räryam karma samäcara \\ asakto hy acaran karma \\ param appoti pürwsah}

karmayogo näma trityo 'dhyäyah, Bhagavadgühà

Therefore, without attachment, perform always the work that has to be done, for man attains to the highest by doing work without attachment.

3rd Chapter, Karma Yoga or the Method of Work, the Bhagvad Gita

Dedicated to

Aai and Baba, my brother, Shalesh and my wife, Vaishali for allowing the to rendin engaged in this effort. 


\section{Contents}

9 Chapter I

Introduction

\section{Chapter II}

Radiofrequency ablation of "class IC atrial flutter" in patients with resistant atrial fibrillation.

Ashish Nabar, Luz-Maria Rodriguez, Can Timmermans, Joep L.R.M. Smeets and Hein J.J. Wellens. (Am J Cardiol 1999;83:785-787)

\section{Chapter III}

Effect of right atrial isthmus ablation on the occurrence of atrial fibrillation: Observations in four patient groups having type I atrial flutter with or without associated atrial fibrillation.

Ashish Nabar, Luz-Maria Rodriguez, Carl Timmermans, Adri van den Dool, Joep L.R.M. Smeets and Hein J.J. Wellens. (Circulation 1999;99: 1441-1445)

\section{Chapter IV}

"Class IC atrial flutter": Electrocardiographic and electrophysiological findings and their importance on long-term outcome after right atrial isthmus ablation.

Ashish Nabar, Luz-Maria Rodriguez, Carl Timmermans, Rob van Mechelen and Hein J.J. Wellens. (Submitred for publication)

\section{Chapter $V$}

Should we prefer a long tip electrode to perform radiofrequency ablation of type I atrial flutter? Results of a prospective randomized study comparing an $8-\mathrm{mm}$ split-tip versus a $4-\mathrm{mm}$ tip ablation catheter.

Luz-Maria Rodriguez, Ashish Nabar, Carl Timmermans and Hein J.J. Wellens. (Am J Cardiol 2000; In Press)

\section{Chapter VI}

Isoproterenol to evaluate resumption of conduction following right atrial isthmus ablation in type $I$ atrial flutter. 
Ashish Nabar, Luz-Maria Rodriguez, Carl Timmermans, Joep L.R.M. Smeets and Hein J.J. Wellens. (Circulation 1999;99: 3286-3291)

\section{Chapter VIII}

Capture and fusion beats during atrial fibrillation and ventricular tachycardia.

Ashish Nabar, Luz-Maria Rodriguez, Carl Timmemans, Klaus Kattenbeck and Hein J.J. Wellens. (Submitted for publication)

\section{Summary}

105 Samenvatting

111 Saraansh

115 Acknowledgements

119 Curriculum vitae

121 List of publications 


\section{Introduction}

Atrial flutter (AFL) is an unique arthythmiat, electrocardiographically characterized by an intriguing monotony in rate ( 300 beats/min) and morphology (inverted "saw tooth" or "picket fence") of the atrial deflections (Figure 1).1.2 Atrial flutter was first described by Jolly and Ritchie in 1911. The incidence of this arrhythmia is uncertain, but is more common in men. ${ }^{4}$ Patients with AFL may have associated structural cardiovascular lesions (like hypertension, coronary artery disease, mitral or tricuspid valve disease or congenital cardiac disease). It may also occur following open heart surgery (like the Mustard or Fontan procedure), or in the presence of a systemic illness (like chronic obstructive pulmonary disease).12 Atrial flutter is usually paroxysmal and not life-threatening, unless associated with conditions like pulmonary edema or $1: 1$ atrioventricular (AV) conduction as in presence of Wolf-Parkinson- White syndrome ${ }^{2}$ Recently, a $7 \%$ overall embolic event rate was observed at 2 year follow-up in patients with $A F L$, which calls attention to a risk of thrombo-embolism seemingly higher than previously thought. ${ }^{3}$

Several animal models have followed the one described by Rosenblueth and Garcia-Ramos, and they have contributed valuable insights into the mechanisms of AFL. 6.7.8,9 These experimental studies suggest that AFL is predominantly a right atrial (RA) reentrant arryythmia, with a clockwise (CW) or counterelockwise (CCW) movement around the tricuspid valve (TV) annulus. It may occut in the presence or absence of an anatomical obstaclc. Electrophysiological studies, including activation mappingand entrainment techiques proneered by Puech of al., "1" and Waldo et al." " supported that AFL in humans is based on a RA macro-reentry moventent with an excitable gap. 12.13 The bulk of evidence currently available confirms that in 8(1-85\% of cases, human AFL crrcuit is in RA (Figure 2). ${ }^{4}$ The unque arrangement and orientation of the atrial nuscle fibers between inferior vema caval (IVC) orifice and TV orifice tr may promote nonumform anisotropic conduction in the so called "isthnus" thus providing a zone of

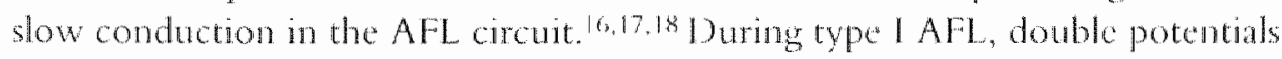
have been recorded along the crista teminalis suggesting that the crista fornis a posterior barrier of the flutter circuit ${ }^{19}$, while the TV ammulus forms an anterion barrier. ${ }^{21}$ Thus, the anatomical barriers provided by the endocardial architecture 

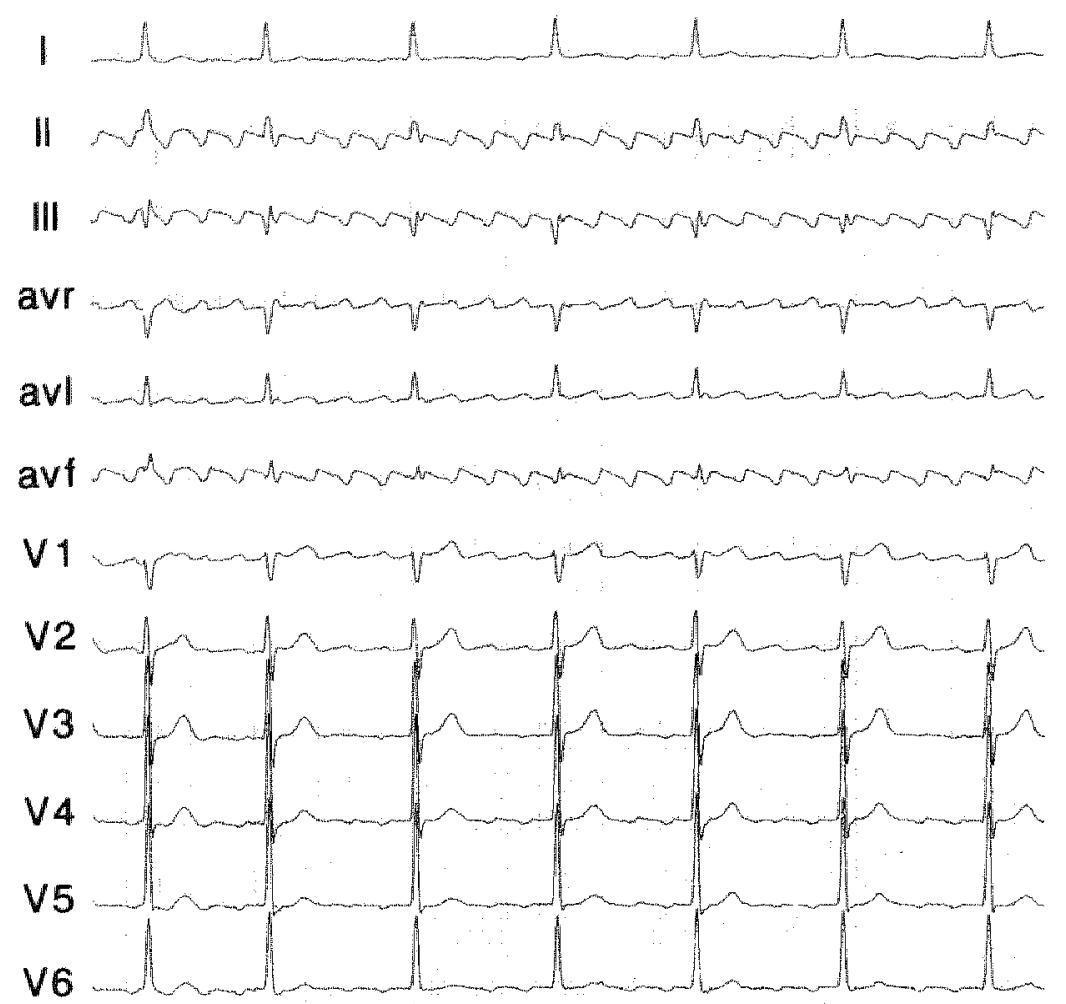
960674

$11400 \mathrm{msec}$

Figure 1. The 12-1od ECG shows typical atrial flutter (AFL), with regular and sharp regative atrial deflections in the inferior leads and positive deflections in lentil.

seems to determine the location of AFL circuit in RA. The left atrium seems to be not essential in the reentry circuit.

Currently, type I (the common or typical) AFL includes the isthmus dependent futter with either $\mathrm{CCW}$ - or $\mathrm{CW}-\mathbb{R A}$ activation in the frontal plane. ${ }^{14,22}$ Non-fluoroscopic mapping ${ }^{17}$ and studies using multiple endocardial electrograms (Figure 3) during pacing induced entrainment of AFL23 have identified the type I AFL circuit completely. In a CCW AFL (Figure 4, Panel A), a bread band of peri-triaspid activation entess the isthmus, slows in its medial part, acconds up the septum, reaths the root of the superior wena cand, usually crossing it anteriorly and rarely fusing around it to deschd dom the free wall. ${ }^{17}$ Clockwise AFL (Figure 4, Panel B), while ruming in the opposite direction, shares the same circuit with the same endocardial borders as the CCW-AFL and is therefore best considered as type I 


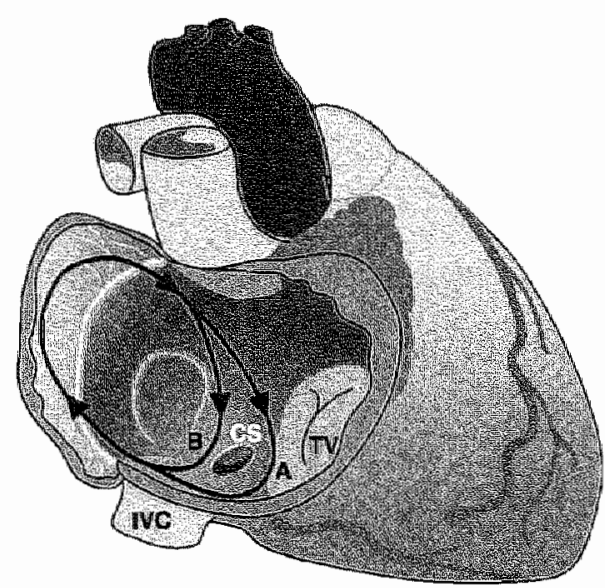

CW

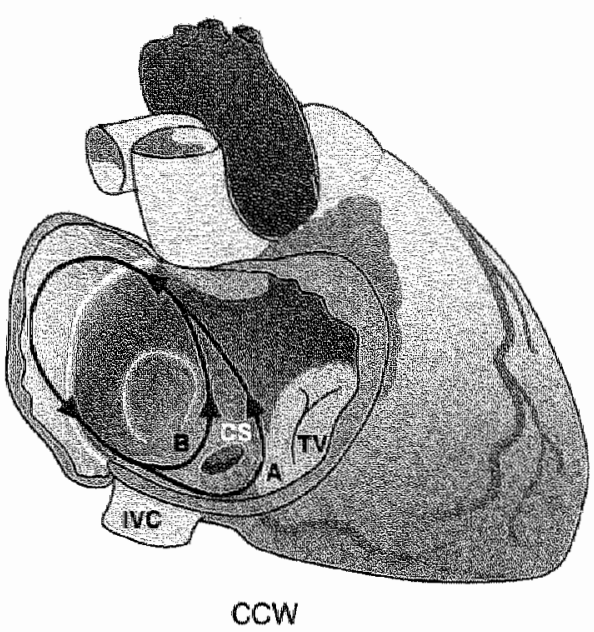

COW

Figure 2. A schenatic representation showing the localization of the type 1 AFL macromecntry circuit in the night atrium (RA). The pand on the left tepesents a dockwise (CW) AFL cincut. The activation wavefront is seen to propagate along the atrial septum cranocadaly, followed by: mediolateral activation of the tricuspid valve (TV) - inferior vena cava (IVC) isthms and caudocanial acrivation of the hateral $\mathrm{R} A$ wall (crista teminalis). The panct on the right represents a counterdockwise (CCW) AFL circuit. In this case, the atrial activation wavefront is sect to propagate craniocaudally along the lateral RA wall (crista teminalis), followed by literonedial active tion of the TV - IVC isthmus and audocranial activation of the atrial septum. In either rotation, the activation wavefront could propagate anterior (A) or posterior (B) to the coronary sinus (CS).

AFL. 14,24,25 Generally, the CCW-AFL is associated with negative "saw-tooth" flutter waves in leads II, III and aVF and positive flutter waves in lead V $1,2,19,22,26$ This ECG pattern is noted in $2 / 3$ ts of all AFLs.26 Positive flutter waves in loads 11 . III and aVF and negative flutter waves in lead V1 are seen with CW-AFL (Figure 5) ${ }^{24}, 26$ However, Saoudi et al., have reported the combination of negative Hutter waves in inferior leads with negative fluter waves in lead V1 in a majority of their patients with CW-AFL. ${ }^{1-4}$ Furthermore, some positive flutter waves in inferior leads are due to $\mathrm{CCW}-\mathrm{RA}$ circuits ${ }^{24}, 26$ while some occur in left atrial reentry circuits. ${ }^{25}$

In an experimental setting, Allessie et al., showed that AFL could occur at numerous places in the atria. ${ }^{727}$ During clincal electrophysiologic studies findings like heterogenous electrocardiographic morphology of the flutter wave, shorter cycle length, difficuly in entramment and tendency for frequent transition to atrial fibrillation (AF) are considered as suggestive for "atypical AFL". 25,2H Left atrial23-32 and surgical scar related ${ }^{3,34}$ flutter are considered as "atypical" since they do not involve the classical "type I" flutter circuit. Recontly, double-wave reentry ${ }^{35}$ and lower loop reentry ${ }^{36}$ have been described as subtypes of type I AFL, to explain the mechanisms of more rapid and irregular AllLs. 

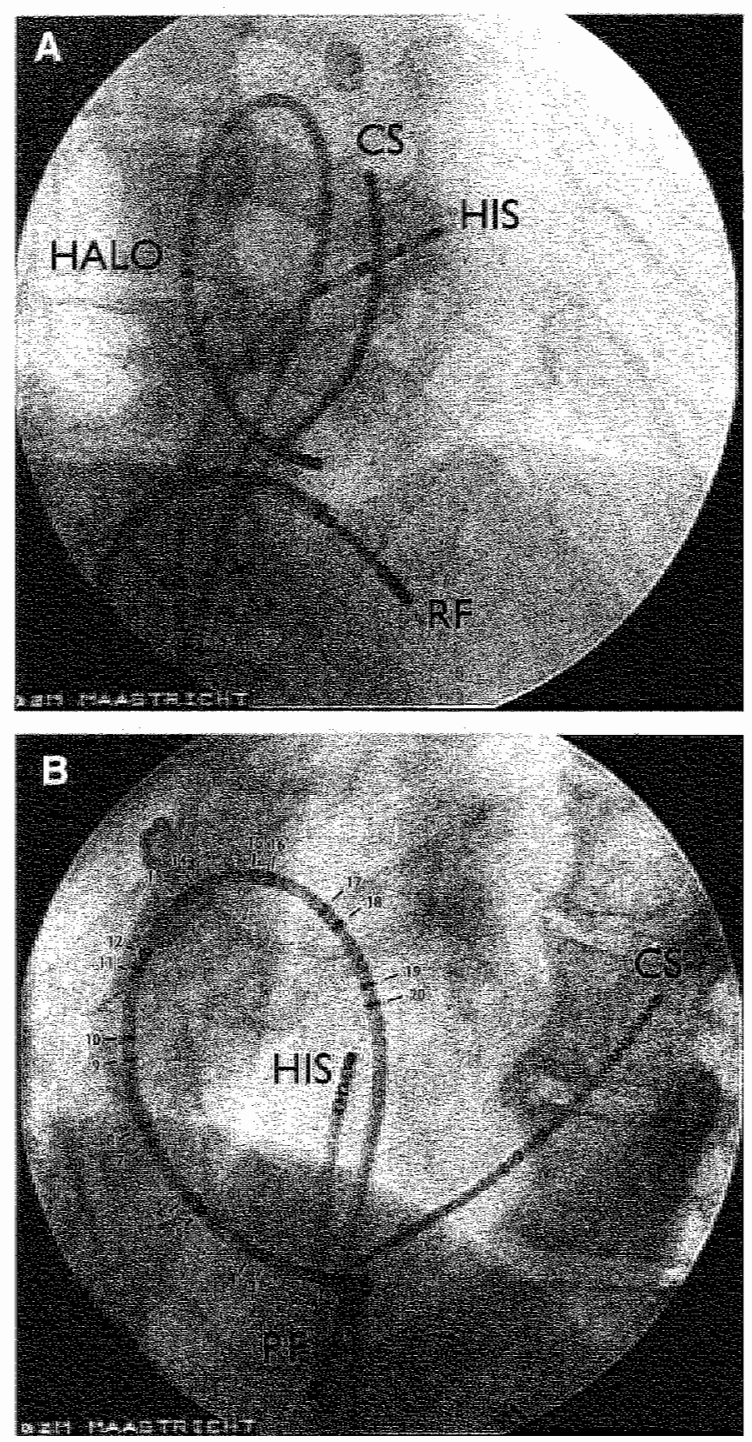

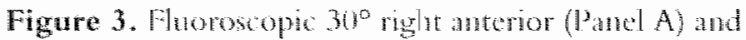
$60^{\circ}$ kef anterior (Panel B) oblique projections showing: a duodecapolar Halo catherer placed around the micuspid anmus (HALO, 1-2 to 19-20 represent the 10 bipoles of the Hato artherery, a dexapolar catherer in the CS, a quadripolat cotherer in the His bunde position (HIS) and a matiotrequency ablation antheter (RP) in the posterion RA isthmus. 

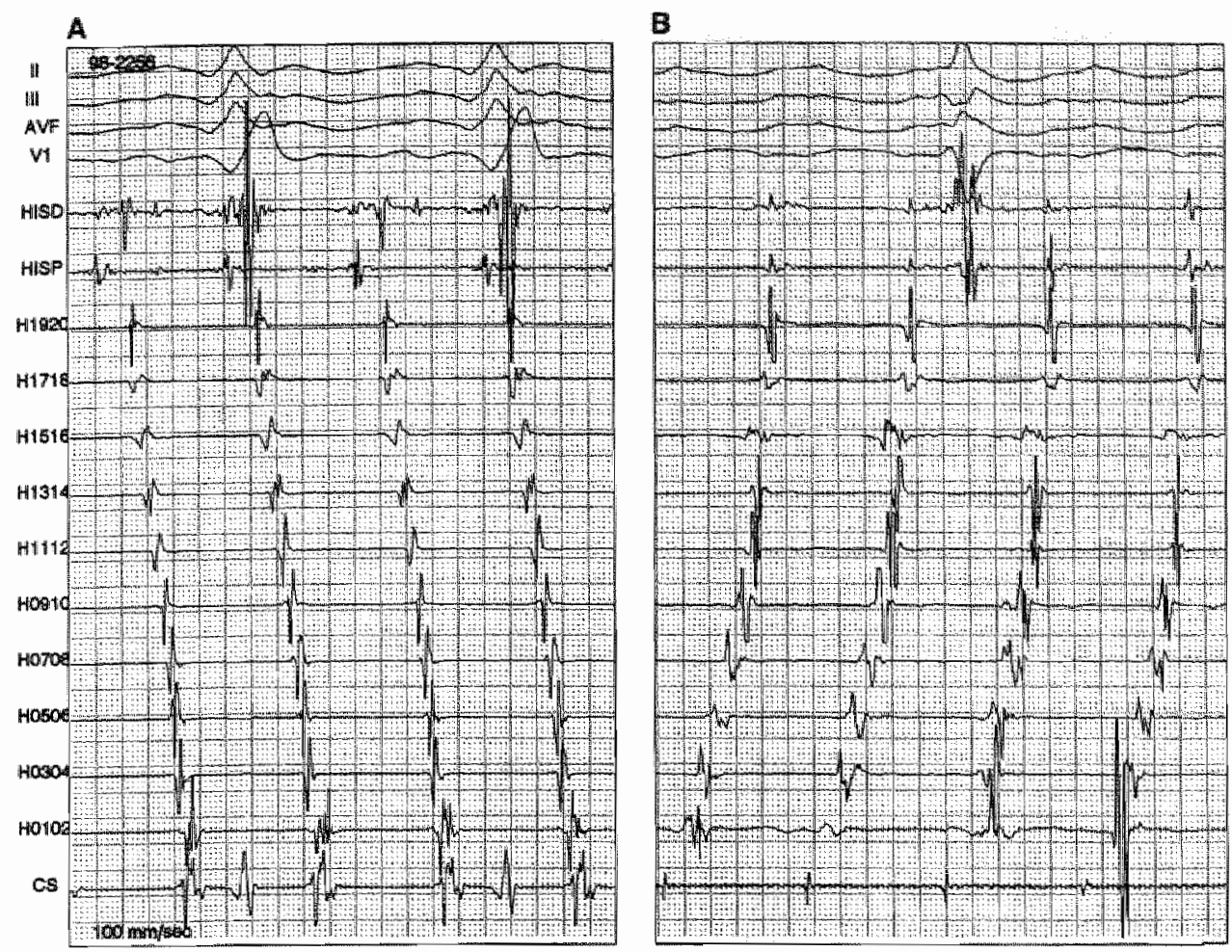

Figure 4. Intra-atrial activation pattern during $\mathrm{CCW}$ (Panel A) and $\mathrm{CW}$ (Panel B) rotation of AFL. ECG leads II, III, $\mathrm{VF}$ and $\mathrm{V} 1$ are shown. The intracardiac electrograms inclade, elecrograms from the His bundle (distal, HISD and proximal, HISP), 10 bipoles of the Halo catheter (H0102 - H1920) and the CS.

Acute treatment of AFL to restore sinus rhythm includes antiarrhythmic drug (AAD) therapy, 37,38 rapid atrial pacing or DC cardioversion. ${ }^{2}$ No drug given intravenously can predictably ensure successful rapid conversion to sinus rhythm. A study comparing the effects of a class III AAD, doferilide with a class I AAD, flecainide, reported the superiority of dofetilide in conversion of AFL to sinus rhythm. ${ }^{3 /}$ Recently, another study comparing the acute effects of class I and class III AADs on the circuits of type I AFL, reported conversion rates with ibutilide, propafenone and amiodarone to be $67 \%, 33 \%$ and $33 \%$ respectively. ${ }^{3 \%}$ Class IA (e.g quinidine, procainamide, disopyramide), class IC (e.g flecainide, propafenone) or class III (e.gamiodarone, sotalol) AADs have been in clinical use for chronic prevention of paroxysms of $\mathrm{AFL}^{2}$ In recent studies, successful interruption by radiofrequency (RF) ablation of isthmus conduction resulted in cure of $\mathrm{AFL}$ in $>95 \%$ of cases ${ }^{40-42}$ The recurrence rate was $<10 \%$ when complete 


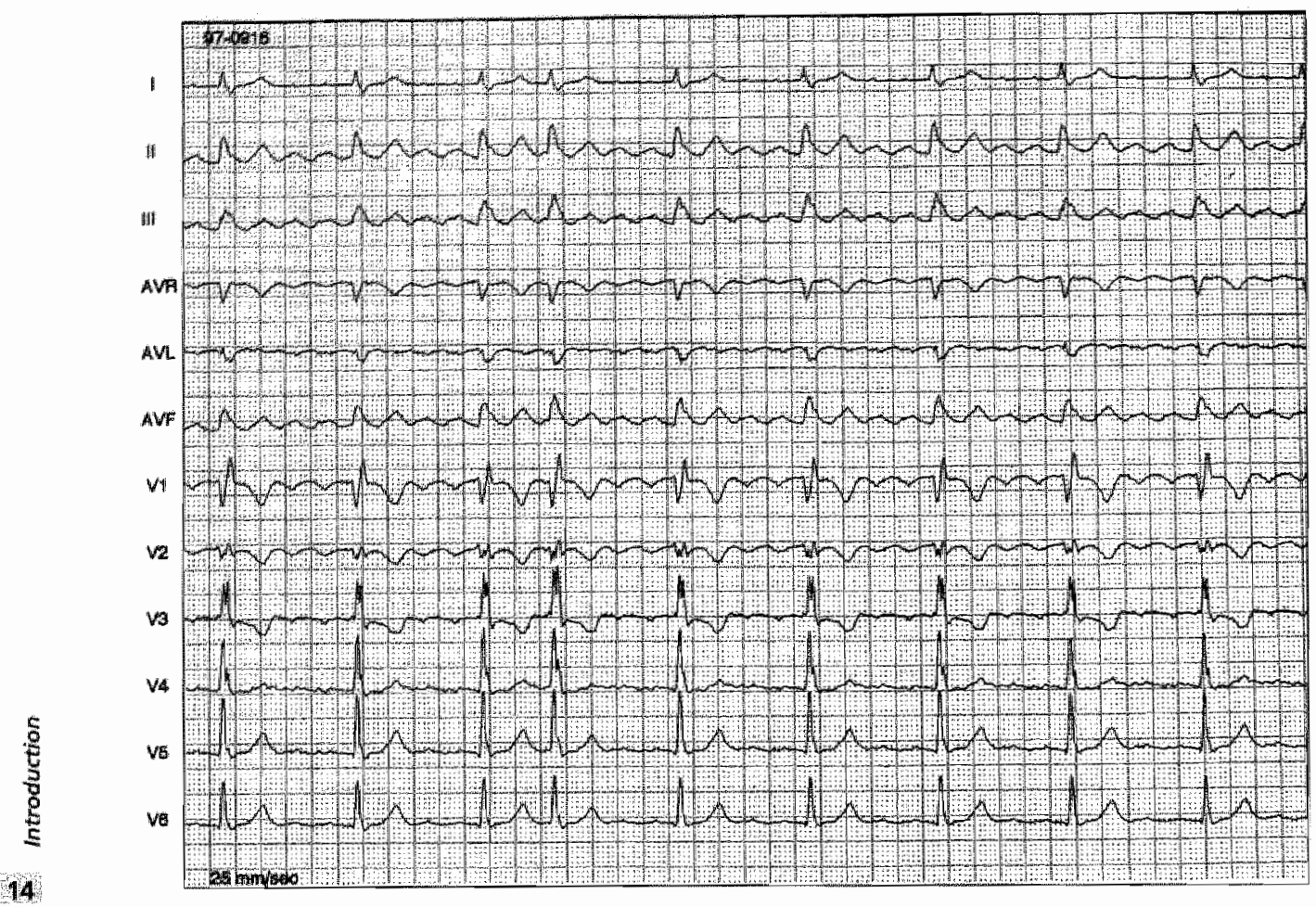

Figure 5. The 12-lead $\mathbb{E} C G$ shows $A E L$, with positive atrial deflections in the inferior leads and negative deflections in lead $V 1$. This parient had a clockwise AFL.

bidirectional isthmus conduction (BIC) block was achieved $40-42$ Catheter ablation of type I AFL is clearly the treatment of choice not only in patients with AFL non-responsive to antiarrhythmic medication, but also in patients preferring this curative therapy above AAD therapy, termination by overdrive pacing, or repeated electrical cardioversion. ${ }^{43,44}$

Atrial fibrillation is currently the most frequent, sustaned, symptomatic tachyarrhythmia in patients with or without structural heart disease requiring hospitalization and has been of growing interest to the electrophysiologist in recent years. $1,45-49$ The incidence of this arthythmia increases with age, estimated to occur in nearly $5 \%$ by age 60 , over $10 \%$ by age 70 , and nearly $20 \%$ by the age of 80 years and is twice as common in males as females. ${ }^{50,51}$ Mechanistically speaking, mapping of electrical excitation during AF has showed that AF is frequently based on multiple wavelets wandering around natural anatomical obstacles and functional arcs of conduction block (random reentry). ${ }^{52,53}$ In some cases the wavelets seem to be an offspring (daughter wave) of a single reentrant circuit (mother wave).52.54 Recently, reports have been published of the 
successful ablation of repetitively firing atrial foci resulting in $A F,{ }^{55,56}$ Clinically, the 3 most important consequences of $A F$ are increased risk of thromboembolism, ${ }^{57}$ tachycardiomyopathy ${ }^{58}$ and heart failure. Restoration and maintenance of sinus rhythm is therefore superior to persistence of ventricular rate control by pharmacological or nonpharmacological intervention together with anticoagulation. ${ }^{59}$ Rate control can be achieved pharmacologically, with agents that impair AV nodal conduction directly and/or by increasing the parasympathetic/sympathetic balance, or anatomically by modifying or ablating the AV nodal region. ${ }^{49,58}$ Return to sinus rhythm can be achieved by electrical or pharmacological conversion followed by pharmacological (or occasionally ablative) therapies. ${ }^{55.601-63}$

Atrial futter and AF may be considered to represent a spectrum of intra-atrial reentry. ${ }^{1,2} \mathrm{Based}$ on the wavelength concept, the wavelength of $\mathrm{AFL}(\approx 9.7 \mathrm{~cm})$ is longer than that of AF $(\approx 7.8 \mathrm{~cm}) .{ }^{64}$ The clinical co-existence of AFL and AF has been estimated to be $25-33 \%{ }^{65.66}$ Atrial fibrillation is often the transitional rhythm for initiating AFL. ${ }^{67,68}$ Atrial flutter and AF may occur at different times in the same patient ${ }^{65}$ and in fact the presence of AFL and AF in different parts of atria at the same time has been shown in patients whose surface ECG suggests AFL.69 A number of experimental ${ }^{70,71}$ and clinical studies ${ }^{72,73}$ have observed that the length of the functional block along the RA free wall (pectinate muscle bundles) determines the transition between AF and AFL. Also, AF is not entirely random as indicated by the periods of "organization" which tend to occur predominantly along the crista terminalis in a craniocaudal direction. 52,74 Such an "organization" is facilitated by AADs. ${ }^{74}$ The likelihood for "organization" of paroxysmal versus chronic AF is uncertain. ${ }^{63}$

The class IC AADs, propafenone and flecainide, have been recommended as first line maintenance therapy to prevent $A F$ recurrences in patients with paroxysmal and persistent AF having no or minimal structural heart disease. 75 "Transformation" of AF to AFL under class IC medication is well-known. $16,76,79$ Increase in the wavelength due to increase in the atrial refractory period in a tachycardia dependent manner, ${ }^{80,81}$ probably explains the class IC antiarrhythmic mediated conversion of AF to AFL. So far, such a conversion to AFL has been considered a proarhythmic effect due to the risk of 1:1 AV conduction. Ortiz et al. ${ }^{70)}$ remarked that ".. of some interest is the recognition that type IC antiarhythwic agents, when used to suppress recurrent AF in patients, sometimes "convert" subsequent episodes to AFL; i.e., a patient who previously presented with AF in the absence of drug therapy may now present with sustained stable AFL, having been treated with a type IC antiarrhythmic agent to suppress episodes of $A F^{\prime \prime}$. The incidence of class IC antiarrhythmic agent mediated conversion to AFL is suggested to be 3.5 to $20 \%, 77,78$ but may be higher when observed systematically. Recently Huang et 
${ }_{1 .}{ }^{82}$ showed clinical benefit following a "hybrid" strategy of RA isthmus ablation and AAD therapy, in patients who experienced conversion of AF to AFL while taking AAD therapy. Most of the patients in that study developed AFL when amiodarone was prescribed for AF.

We define "class IC atrial flutter" as a new AFL developing in patients receiving class IC AADs for recurrent episodes of $A F$. Our hypothesis was, that successful RF ablation of the RA isthmus in patients with resistant AF who develop AFL while receiving class IC antiarrhythmic therapy could favorably modify the "natural" course of AF. The short-term results of this "hybrid" approach ( $\mathrm{n}=14$ patients) are presented in Chapter II of this thesis. Another group, using the same approach obtained equivalent results with regard to AF recurrences. ${ }^{83}$

Linear ablation of the RA isthmus is an effective and curative therapy for type I AFL. High procedural success (>95\%) and low recurrence $(<10 \%)$ rate are reported following documentation of $B I C$ block. ${ }^{4(0-42,85,86}$ Long-term success of RF ablation of AFL may be undone by the occurrence of AF, either preexisting or developing de novo. ${ }^{87,88}$ A recent study found that palpitations following successful RA isthmus ablation for type I AFL are mostly due to AF and not due to AFL recurrences. 89 The risk of postablation AF recurrences is higher $(8-30 \%)$ in patients with a history of spontaneous AF, structural heart disease, enlarged left atrial size, left ventricular ejection fraction $<50 \%$, a higher number of previously failed AADs, and inducible AF following AFL ablation. ${ }^{86,88,90}$ In Chapter III, we tested the hypothesis that at least in some patients with coexisting type I AFL, maintenance of AF may be based on a macro-reentry around the TV orifice, including the RA isthmus. The entire patient population $(n=82)$, who underwent RF ablation of the RA isthmus by an anatomical approach, was divided into 4 groups after a careful review of the available ECGs and 24-hour Holter recordings. These 4 groups were: Group I, only AFL; Group II, AFL>AF; Group III, $A F>A F L$ and Group IV, "class IC AFL". Long-term occurrence of AF following successful ablation of the RA isthmus was examined.

Antiarthythmic drugs, ${ }^{65,82,91,92}$ including class IC agents, ${ }^{76-79,83}$ convert AF to AFL by slowing conduction and causing prolongation of the atrial refractory period, thereby creating functional lines of inter- and intra-atrial block thus leading to transfomation of random reentry into organized stable reentry. In the literature, reports on ablation of AFL which developed while taking AAD therapy for recurrent AF, suggest a predominant occurrence of typical AFL.82,83 In tew patients, atypical ECG and intracardiac electrogram patterns have been documented. ${ }^{82,83}$ The aim of the study presented in Chapter IV ( $\mathrm{n}=24$ patients) was 2-fold: 1) to describe the ECG morphology and electrophysiologic findings during RF ablation of "class IC AFL" and 2) to report long-term success 
following RA isthmus ablation, in relation to their ECG pattem during AFL. The usefulness of the "hybrid" approach will depend upon the results obtained at long-term.

Ablative therapy for AFL has made tremendous progress in the nineties, and is currently considered as curative management of type I AFL. "There has been a progressive shift in the ablation techniques; from DC shocks to $\mathrm{RF}$ energy, $14,25,40-42,84-80,94-103$ and from an electrophysiological (focal) , $^{94}$, to an anatomical (linear) approach. ${ }^{14,25,40-42,8486,96-101}$ The IVC - TV annulus was identified as the "isthmus" yielding maximum procedural success. $41.84-86.98-101$ This was followed by the recognition of septal isthmus. 42 Complete BIC block was found to be a superior criterion of successful futter ablation resulting in low recurrence rate ${ }^{4,84-86,101}$ as compared to nominducibility alone. ${ }^{9490}$ It was also shown that ablation during sinus rhythm $4,85,101$ should be preferred as compared to ablation during AFL. ${ }^{949}$ Furthermore, it is now understood that $\mathrm{CW}-\mathrm{AFL}$ use the same circuit and isthmus as CCW rype I AFL and can be ablated successfully by the same approach. ${ }^{14,102}$ Finally, AFL recurrences can easily be re-ablated by detecting "gaps" in the isthmus conduction. 103

Present day concerns during the ablation of type I AFL are related to the use of multiple RF applications, which may be delivered at unintended sites ${ }^{104}$ and could be potentially proarthythmic. ${ }^{105} \mathrm{R}$ isks related to long radiation exposure need careful consideration in planning the ablation procedure. ${ }^{106,107}$ Langberg et al., ${ }^{108}$ and more recently Otomo et al., ${ }^{109}$ reported an 8-mm tip as a more optimal RF electrode size for making linear lesions. The orientation of the ablation electrode determines the electrode-tissue interface and therefore the size of lesion created. ${ }^{109,110}$ The available clinical experience with the use of large tip electrodes for RF ablation of AFL is small and observational, $1,42,87,88,111$ These issues made us decide to compare an 8-mm split-tip electrode with two integrated themocouples allowing independent temperature monitoring (Cerablate plus Fluter, Dr Osypka GmbH) with a 4-mm tip electrode ablation catheter, for RF ablation of type I AFL, in a prospective randomized mamer. The purpose of this prospective study was to answer the question "Should ac prefer along tip electrode fo perform radiofrequency ablation of type I arrial fluter?" That study is presented in Chapter V. Currently, several other methods to produce deeper and wider isthmus lesions are being evaluated, both in climical and in experimental setring. They include the use of the irrigated-tip catheter, ${ }^{12}$ microwave energy ${ }^{113}$ and the bipolat two catheter technique. ${ }^{114}$

Atral flutter recurrences are associated with failure to achieve complete BIC block at the end of the ablation procedure. 86 A complete BIC block is a superior endpoint as compared to undirectional isthmus conduction block or BIC delay, $41.85,86,191$ Repeat electrophysiologic studies in patients with an AFL recur- 


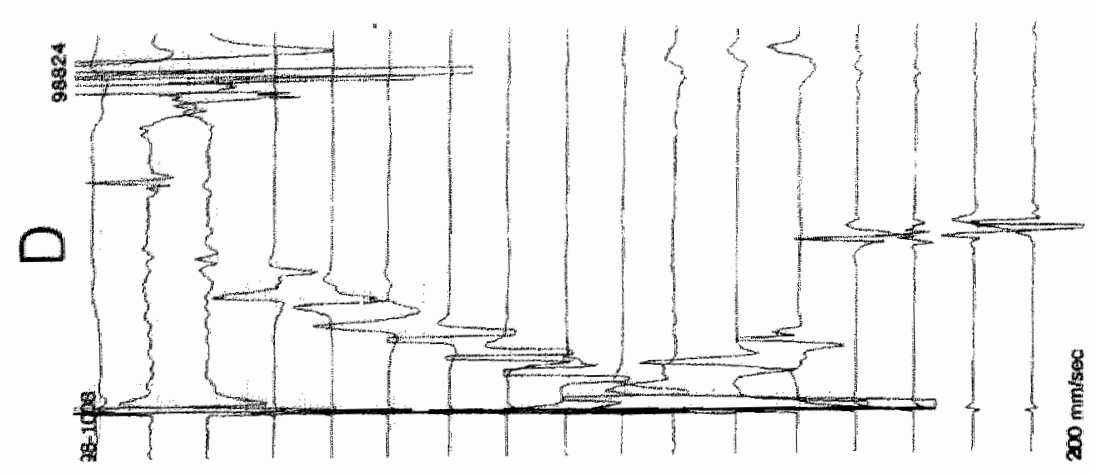

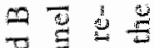

을

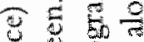

E

$00 \%$

U.

*5

的

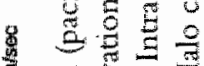

E $<\stackrel{2}{E}$

8 氜 㐘

$\therefore \leq 20$

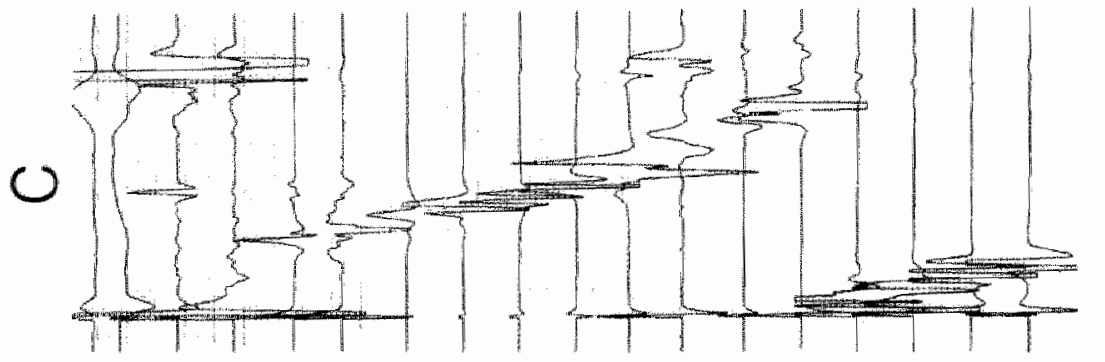

क荙

总吉导

7) $E$.

$500 \pm 0$

응 $\frac{\pi}{2}$

窟岛出

을

5 50

ㄴ. 뭉

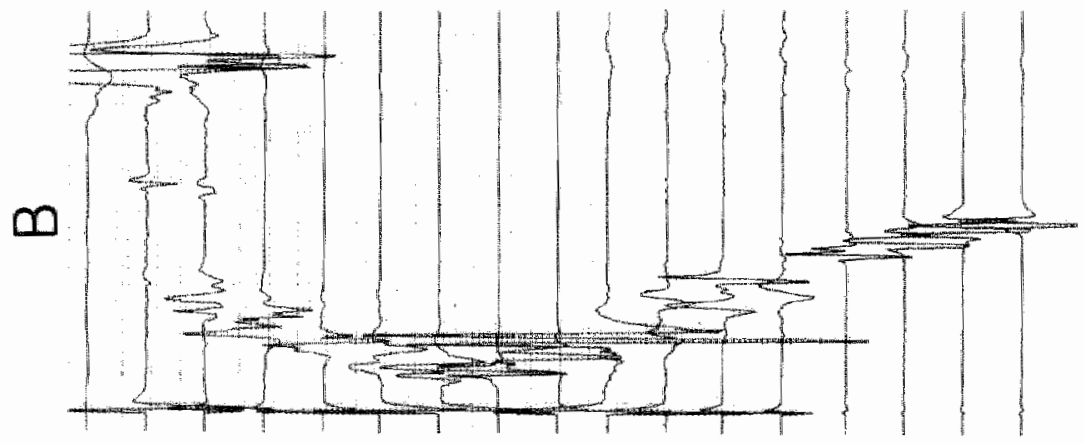

क्ष

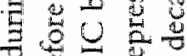

O.

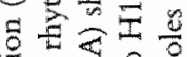

: $28 \%$

$\exists \sqrt{3} \mathrm{~g}$

解

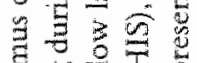

soㄴㄹ

$\therefore$ 的

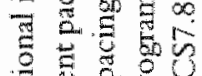

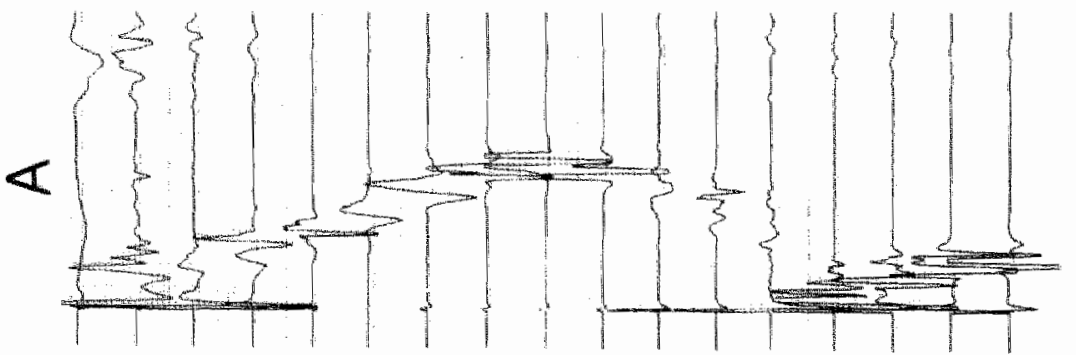

政

总包岂

3 흔

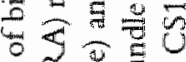

5

洁喓

3033

(4) 㟧

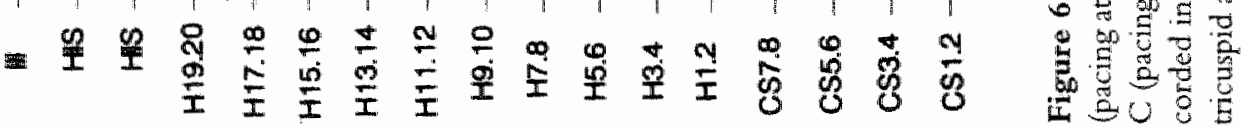


rence show regression or complete disappearance of isthmus conduction block. ${ }^{85}$ A BIC block is confirmed by pacing alternately from the coronary sinus and low lateral RA at a constant cycle length $\left(600\right.$ or $500 \mathrm{~ms}$ ) (Figure 6). ${ }^{41}$ A mediolateral isthmus conduction block ${ }^{115}$ is defined by an entirely craniocaudal activation of the lateral RA wall during proximal CS (CS7.8) pacing with terminal activation of the Halo 1.2 bipole and prolongation of the CS7.8 - Halol.2 interval. A lateromedial isthmus conduction block ${ }^{115}$ is defined by a caudocranial activation of the lateral RA wall and craniocaudal activation of the atrial septum with terminal activation of CS7.8 following activation of the His bundle during low lateral $\mathbb{R A}$ pacing. Resumption of isthmus conduction due to reversal of block has been observed within 30 minutes and sometimes as late as 1 thour following the last RF application. ${ }^{40,101}$ At times, AFL may remain inducible despite apparent BIC block. ${ }^{116}$ These observations may be based on: misinterpretation of isthmus conduction slowing as a block or rate dependent isthmus conduction block, 41,97,101,117 or anatomical reasons: presence of "gaps"98 or alteration in the propagation of the flutter circuit around the coronary sinus ostium. ${ }^{42.118}$ Efforts to obtain a complete and permanent line of BIC block, include demonstration of a complete line of double potentials, ${ }^{119}$ bipolar electrogram polarity mapping, ${ }^{120}$ recording from a closely spaced multipolar catheter placed in the isthmus ${ }^{121}$ or use of non-fluoroscopy CARTOTM (Biosense Ltd, Israel) ${ }^{119,122}$ or non-contact electrode (MEA, Endocardial solutions, Minneapolis, MN) ${ }^{123}$ mapping systems. The purpose of the study described in Chapter VI was to test the persistence of BIC block following isoproterenol administration and to evaluate the importance of this finding for AFL recurrences.

Chapter VII reports two previously unpublished observations made during an electrophysiological study: 1) induction of idiopathic ventricular tachycardia by $\mathrm{AF}$, and 2) the presence of fusion and capture beats during two simultaneously occurring arrhythmias, AF at the atrial level and idiopathic ventricular tachycardia at the ventricular level.

\section{References}

1. Josephson ME. Atrial flutter and fibrillation. In: Josephson ME, ed Chinical Cardiac Electrophysiology: Techniques and Interpvetations. Philadelphia, Lea and Febiger 1993:275-310.

2. Waldo AL. Atrial flutter: mechanisms, clinical features, and management. In: Zipes DP, Jalife J, eds: Cardiac Electrophysiology: From Cell to Bedside. WB Saunders Co., Philadelphia, 1995:666-681.

3. Jolly WA, Ritchie WJ. Auricular flutter and fibrilation. Heart 1911;2:177-221. 
4. Bellat S. Chinal disoders of the heant beat. Philadelphia, Lea and Febiger, $1963: 144-145$.

5. Seidl $K$, Hauer B, Schwick NG, Zellner D, Zahn R. Senges J. Risk of thromboembolic events in patients with atrial futter. Am I Camol $1998,82: 580-583$.

6. Rosenblueth A, Garcia-Ramos J. Studies on flutter and fibrillation. II. The influence of artificial obstacles on experimental auricular flutter. Am Heart $\mathrm{J}$ $1947 ; 33: 677-684$

7. Allessic MA, Lammers WJEP, Bonke FIM, Hollen J. Intratarial reentry as a mechanism for atrial tutter induced by acetylcholine in rapid pacing in the dog. Cirulation 1984;70:123-135.

8. Frame LH, Page RL, Hoffman BF. Atrial reentry around an anatomic barrier with a partially refractory excitable gap. A canine model of a atrial futter. Cinc Res $1986 ; 58: 495-511$.

9. Frame $L H$, Page $\mathbb{R L}$, Boyden $\mathbb{P A}$, Fenoglio J Jr, Hoffman BF. Circus movement in the canine atrium around the tricuspid ring during experimental atrial futter and during reentry in vivo. Civmlation 1987;76:1155-1175.

10. Puech P, Latour $H$, Grolleau $\mathbb{R}$. Le fluter et ses limites. Arh Mal Coew $1970 ; 63: 116-144$.

11. Waldo AL, MacLean WAH, Karp RE, Kouchoukos NT, James TN. Entranment and interruption of atrial flutter with atrial pacing: studies in man following open heart surgery. Circulation 1977;56:737-745.

12. Della Bella $\mathbb{P}$, Marenzi $G$, Tondo $C$, Cardinale $D$, Giraldi $F$, Lauri $G$, Guazzi M. Usefulness of excitable gap and pattern of resetting in atrial flutter for determining reentry circuit location. Am J Cardiol 1991;68:492-497.

13. Callans DJ, Schwartzman D, Gottieb CD, Dillon SM, Marchlinski F. Characterization of the excitable gap in human type I atrial flutter. I An Coll Cardiol $1997: 30: 1793-1801$.

14. Saoudi $N$. Nair M, Abdelaziz A, Poty H, Daou A, Anselme F, Letac B. Electrocardiographic pattems and results of radiofrequency atheter ablation of clockwise atrial fluter. I Cardionas Elechophysiol 1996;7:931-942.

15. Cabren JA. Sanchez-Qumtana D, Ho SY, Medina A, Anderson RH. The architecture of the atrial musculature between the orfice of the inferior caval vein and the cricuspid valve: the anatomy of the isthmus. I Cardiouas Electrophysiol $1998.9: 186-1195$

16. Olkhanky B, Okumura K, Hess PG, Waldo AL. Demonstration of an area of slow conduction in human atrial fluter. IAw Coll Cardiol 1990;16:1639-1648.

17. Shat DC, Jäis P, Haissaguere M, Chouari S, Takahashi A, Hocin M, Garrigue S, Comenty ]. Three-dimensional mapping of the common atrial tutter circuit in the right atrium. Ciralation 1997:96:3904-3912.

18. Fenelon $G$, Brugada $P$. Unipolar wavetoms and monophasic action potentials in the characterization of slow conduction in human atrial futter. Pacing Clin Electroplysiol $1998: 21: 2580-2587$. 
19. Olgin JE, Kalman JM, Fitzpatrick AP, Lesh MD. Role of right atrial endocardial structures as barriers to conduction during human type 1 atrial thuter activation and entrainment mapping guided by intracardiac echocadiography. Curtuation 1995:92:1839-1848.

20. Tai CT, Chen SA, Chen YJ, Yu WC, Hsieh MH, Tsa CF, Chen CC, Ding YA, Chang MS. Conduction properties of the crista terminalis in patients with apical atrial flutter: basis for a line of block in the reentrant circuit. I Cardions Electrophyiol $1998,9.811-819$

21. Kalman J, Olgin J, Saxon L, Fisher WG, Lee RJ, Lesh M. Activation and entrainment mapping defines the tricuspid annulus as the anterior barrier in typical atriat Autter. Ciralation 1996;94:398-406.

22. Shah DC, Haissagueme M, Jais P, Takahashi A, Clementy J. Atrial fluter: Contemporary electrophysiology and catheter ablation. Pacing Chin Electrophsiol $1999 ; 22: 344-359$.

23. Arrabas F, López-Gill M, Cosio F, Nunez A. The upper link of human common atrial futter circuit: definition by multiple endocardial recordings during entrainment. Pacing Clin Electrophysial 1997;20:2924-2929.

24. Cosio FG, Goicolea A. López-Gil M, Arribas F, Barroso JL, Chicote R. Arrial endocardial mapping in the rare form of atrial futter. Am J Cardiol 1990;66:715-720.

25. Kalman JM, Olgin JE, Saxon LA, Lee RJ, Scheimman MM, Lesh MD. Electrocardiographic and electrophysiologic characterization of atypical atrial futter in man: use of activation and entrainment mapping and implications for catheter ablation. I Cadiovasc Electrophysiol 1997;8:121-144.

26. Cosío FG, Arribas F, López-Gil M, Palacios J. Atrial futter mapping and ablation I. Studying arrial futter mechanisms by mapping and entramment. Paring Clim Elctrophysial 1996,19:841-853.

27. Allessie M, Lammers W, Smeets J, et al. Total mapping of atrial excitation during acetylcholine-induced atrial fluter and fibrillation in the isolated camilge heart. In: Kubertus HE, Olsson SB, Schepper M, eds: Atrial fibrillation. Molndal, Sweden, AB Hasell, 1982:4-59.

28. Arenal A. Almendral J, Romàn DS, Delcan JL, Josephon ME. Frequency and implications of resetting and entranment with right atrial stimulation in atrial flutete. Am J Cardiol 1992;70:1292-1298.

29. Jais $\mathrm{P}$, Haissaguerre $M$, Shah $\mathrm{D}$, Takahashi $\mathrm{A}$, Lavergne $T$, Cleménty J. A new electrophysiological substrate for spontaneous left atrial fluters. Cimolation 1998,98 (Suppl):1-19. Abstract.

30. Natale A, Richey M, Tomassoni GF, Beheiry S, Rajkovich K. Wides B, Wickell D, Leonell FM. Clinical characteristics and ablation of left sided atrial tutter. I Am Coll Cardiol 1999;33(Suppl):116A.Abstrat.

31. Kall JG, Lin AC, Johnson T, Cooke P, Kopp D, Burke M, Verdino R. Wang Z, Fuomo M, Wilber D. Characteristics of conduction within non-incisional arypical atrial fluter circuits. I An Coll Cardol 1999;33(Suppl):1 16 A Abstract. 
32. Bogun F, Bender B, Li YG, Hohnloser SH, Goethe JW. Concealed entramment in radiofrequency catheter ablation of atypical atrial Hutter in patients without prior cardiac surgery. I Am Coll Cardiol 1999:33(Suppl):116A.Abstract.

33. Wan Hare GF. Electrical-anatomical correlations between typical atrial futter and intra-atrial rentry following atrial surgery. J Electrocardiol 1998;30:77-84.

34. Li W, Somerville]. Atrial flutter in grown-up congenital heart (GLCH) patients: definition of characteristics. I Am Coll Cardiol 1999;33(Suppl):533A.Abstract.

35. Cheng J, Scheinman MM. Characteristics of double-wave reentry induced by programmed stimulation in patients with typical atrial flutter. Cimulation $1998 ; 97: 1589-1596$.

36. Cheng J, Cabeen WR, Scheimman MM. Right atrial flutter due to lower loop reantry. Mechanisms and anatomic substrates. Cirmlation 1999;99:1700-1705.

37. Crijns HJGM, van Gelder 1C, Kingma JH, Dunselman PHJM, Gosselink ATM, Lie KI. Atrial futter can be terminated by a class III antiarrhythmic drug but not by a class IC drug. Eur Heort J 1994;15:1403-1408.

38. Ellenbogen KA, Stambler BS, Wood MA, Sager PT, Wesley RC, Meissner MD, Zoble $\mathrm{RG}$, Wakefield $\mathbb{L} \mathrm{K}$, Perry $\mathrm{KT}$, Vanderlught JT for the Ibutilide Investigators. Efficacy of intravenous ibutilide for rapid termination of atrial fibrillation and atrial flutter; a dose-response study. I Am Coll Cardiol 1996:28:130-136.

39. Tai CT, Chen SA, Feng AN, Yu WC, Chen YJ, Chang MS. Electropharmacologic effects of class I and class III antiarrhythmia drugs on typical atrial flutter. Insights into the mechanism of temination. Circulation 1998;97:1935-1945.

40. Cauchemez B, Haissaguene M, Fischer B, Thomas O, Cleménty J, Coumel P. Electrophysiological effects of catheter ablation of inferior vena cava - tricuspid annulus isthmus in common atrial fhutter. Circhation 1996:93:284-294.

41. Poty H, Saoudi N, Nair M, Anselme F, Letac B. Radiofrequency catheter ablation of atrial flutter: further insights into various types of isthmus block: application to ablation during sinus rlyythm. Circhlation 1996:94:3204-3213.

42. Nakagawa H, Lazzata R, Khastigir T, Beckman KJ, McClelland JH, Imai S, Putha IV. Becker AE, Aruda M, Gonzalez MD, Widman LE, Rome M, Neuhausser J, Wang X. Calame JD, Goudeau MD, Jackman WM. Role of tricuspid annulus and eustachian valve/ ridge on atrial tlutter. Relevance to catheter ablation of the septal isthmus and a new technique for rapid identification of ablation success. Circulation $1996 ; 94: 407-424$.

43. Grifith M), Gammage MD, Radiofrequency ablation of macro-trentrant arthythmias: cure or adjunctive therapy. Lance 1998;352:1404-1405.

44. Morady F. Radiofrequency ablation as treatment for cardiac arrhythmias. $N$ Engl $J$ Med 1999;340:534-544.

45. Olsson SB. Atrial fibrillation - new aspects of mechanism and treatment. I Int Med $1996 ; 239: 3-15$

46. Pritchett ELC. The case for just "plain atrial fibrillation". Pacing Clin Electrophysiol $1997 ; 21: 637-640$ 
Chaprer 1 mroduction

47. Gallagher MM, Camm AJ. Classification of atrial fibrillation. Pacing Clm Electrophysiol 1997;20:1603-1605.

48. Peters NS. Atrial fibrillation: towards an understanding of initiation, perpetuation, and specific treatment. Heart 1998;80:533-534.

49. Blitzer M, Costeas C, Kassotis J, Reiffel JA. Rhythm management in atrial fibrillation - with a primary emphasis on pharmacological therapy. Part I. Paring Clin Electrophysiol 1998:21:590-602.

50. Kannel WB, Abbot RD, Savage DD, McNamara PM. Epidemiologic features of atrial fibrillation. The Framingham Study. N Engl J Med 1982;306:1018-1022.

51. Benjamin EJ, Levy D, Vaziri SM, D'Agostino RB, Belanger AJ, Wolf PA. Independent risk factors for atrial fibrillation in a population based cohort. The Framingham Heart Study. JAMA 1994;171:840-844.

52. Konings KTS, Kirchoff CJHJ, Smeets JLRM, Wellens HJJ, Penn OC, Allessic MA. High-density mapping of electrically induced atrial fibrillation in humans. Ciralation $1994: 89: 1665-1680$

53. Allessie MA, Lammers WJEP, Bonke FMM, Hollen SJ. Experimental evaluation of Moe's multiple wavelet hypothesis of atrial fibrillation. In: Zipes DP, Jalife I, eds: Cardiac Electrophysiology: From Cell to Bedside. WB Saunders Co., Philadelphia, $1995: 265-275$.

54. Cox JL, Canavan TE, Schwessler RB, Cain ME, Lindsay BD, Stone CM, Smith PK, Corr PB, Boineau JP. The surgical treatment of atrial fibrillation. II. Intrapperative electrophysiologic mapping and description of the electrophysiologic basis of atrial flutter and atrial fibrillation. J Thor Card Surg 1991;101:406-426.

55. Jäis P, Hailssaguerre M, Shah DC, Chouairi S, Gencel L, Hocini M, Clémenty J. A focal source of atrial fibrillation treated by discrete radiofiequency ablation. Circulation 1997;95:572-576.

56. Haissaguerre M, Jais P, Shah DC, Takahashi A, Hocini M, Quiniou G, Garrigue S, Mouroux AL, Métayer PL, Clémenty J. Spontaneous initiation of atrial fibrillation by ectopic beats originating in the pulnonary veins. $N$ Engl $I$ Med $1998 ; 339: 659-666$

57. Schlepper M. Identification of patients with atrial fibrillation at risk for thromboembolism. In: OIsson SB, Aljessie MA, Campbell RWF, eds. Arrial Fibrilla fron. Medanisms and Therapentic Strategies. Amonk, NY:Futura Publishing Co., 1994;15-24.

58. Rodriguez LM, Sneets JLRM, Bayan Xie, de Chillou C, Cheriex EC, Pieters F, den Dulk K. Wellens. HJJ. Improvement of left ventricular function by ablation of atrioventricular nodal conduction in selected patients with Jone atrial fibrillation. Am J Cardiol 1993;72:1137-1141.

59. Watkare JEP, Camm AJ. Acute treatment of atrial fbrillation: why and when to maintain sinus thythm. Am J Cardiol 1998;81:3C-15C.

60. Costeas $C$, Kassotis J, Blizer M, Reiffel JA. Rhythm management in atrial fibrillation-with a primary emphasis on pharmacological therapy: Part 2. Paring Clin Electrophysial 1998;21:742-752. 
61. Kassotis J, Costeas C, Blitzer M, Reiffel JA. Rhythm management in atrial fibrillation-with a primary emphasis on phamacological therapy:Part 3. Pacing Clin Electrophysial 1998;21:1133-1145.

62. Haissaguerre M, Jais P, Shah DC, Gencel L, Pradeau V, Garrigues S, Chouairi S, Hocini M, Métayer PL, Roudaut $R$, Clémenty J. Right and left atrial radiofrequency catheter therapy of paroxysmal atrial fibrillation.J Cardiovasc Electrophysiol 1996; 7:1132-1144.

63. Gajta F, Riccardi R, Calò L, Scaglione M, Garberoglio L, Antolini R, Kirchner M, Lamberti $\mathbb{F}$, Richiardi $\mathrm{E}$. Atrial mapping and radiofrequency catheter ablation in patients with idiopathic atrial fibrillation: electrophysiological findings and ablation results. Circulation 1998; 97:2136- 2145.

64. Rensma PL, Allessie MA, Lammers WJEP, Bonke FIM, Schalij MJ. Length of excitation wave and susceptibility to reentrant atrial arrhythmias in normal conscious dogs. Circ Res 1988;62:395-410.

65. Tunick PA, McElhinney L, Mitchell T, Kronzon I. The alternation between atrial flutter and atrial fibrillation. Chest 1992;101:34-36.

66. Murdock CJ, Kyles AE, Yeung-Lai-Wah JA, Anzhen Q, Vorderbrugge S, Kerr $\mathrm{CR}$. Arrial flutter in patients treated for atrial fibrillation with propafenone. Am J Cardiol 1990;66:755-757.

67. Watson RM, Josephson ME. Atrial flutter. I. Electrophysiologic substrates and modes of initiation and termination. Am J Cardiol 1980;45:732-741.

68. Waldo AL, Cooper TB. Spontaneous onset of type I atrial flutter. $J$ Am Coll Cardiol $1996 ; 28: 707-7112$.

69. Gomes JAC, Kang PS, Matheson M, Gough WB, El-Sherif N. Co-existence of sick sinus rhythm and atrial flutter-fibrillation. Circulation 1981;63:80-86.

70. Ortiz J, Niwano S, Abe H, Rudy Y, Johnson NJ, Waldo AL. Mapping the conversion of atrial flutter to atrial fibrillation and atrial fibrillation to atrial flutter. Insights into mechanisms. Cive Res 1994;74:882-894.

71. Wu TJ, Yashima M, Xie F, Athill CA, Kim YH, Fishbein MC, Qu Z, Garfinkel A, Weiss JN, Karaguezian HS, Chen PS. Role of pectinate muscle bundles in the generation and maintenance of intra-atrial reentry. Potential implications for the mechanisn of conversion between atrial fibrillation and atrial flutter. Cire Res $1998 ; 83: 448-462$.

72. Emori T, Fukushima K, Saito H, Nakayama K, Ohe T. Atrial electrograms and activation sequences in the transition between atrial fibrilation and atrial flutter. $J$ Cardionase Elcotroplysiol 1998;9:1173-1179.

73. Roithinger FX, Karch MR, Steiner PR, SippensGroenewegen A, Lesh MD. Relationship beween atrial fibrillation and typical atrial flutter in humans. Activation sequence changes during spontancous conversion. Circhlation 1997;96:3484- 3491 .

74. Roithinger FX. SippensGroenewegen A, Karch MR, Steiner PR, Ellis WS, Lesh MD. Organized activation during atrial fibrillation in man: endocardial and electrocardiographic manifestations. J Cardionas Elcotrophysiol 1998;9:451-46.1. 
75. Pratt CM. Impact of managed care on the treatment of atrial fibrillation. An I Cardiol 1998:81:30C-34C.

76. Feld GK, Chen PS, Nicod P. Fleck P, Mezer D. Possble atrial proarnythmic effect of class IC antiarrhythmic drugs. Am J Cadiol 1990,66:378-383.

77. Marcus $\mathrm{Fl}$. The hazards of using type $1 \mathrm{C}$ antianhythmic dng for the treatment of paroxysmal atrial fibrillation. An J Cardiol $1990 ; 66: 366-367$.

78. Falk RH. Proamhythmic responses to atrial antiarhythmic therapy. In. Falk RH, Podrid PJ, eds. Arral fibrillation: Mechanisms and Management. New York: Raven Press Ltd., 1992:283-305.

79. ElmHarari MB, Adams PC. Atrial flutter with 1:1 atrioventricular conduction caused by propafenone. Pacing Clin Electrophyiol 1996;21:1999-2001.

80. Crins HJGM. Cimical manifestations of use- and reverse-use dependence. In: Crijns HJGM, ed. Changes of intra-cardiac conduction induced by antiarthythmic drugs: Importance of use- and reverse-use dependence. Groningen, Netherlands: BV Knoop Haren; 1993:38-105.

81. Matsuo K, Kumagai K, Amnoura M, Ideishi M, Arakawa K. Mechanism of antiarrhythmic effects of class Ic drugs in paroxysmal atrial fibrillation in man. Cardiology 1998;89:119-123.

82. Huang DT, Monahan KM, Zimetbaum P, Papageorgiou P, Epstein LM, Josephson ME. Hybrid pharmacologic and ablative therapy: a novel and effective approach for management of atrial fibrillation. J Cardiowas Electroplysiol 1998;9:462-469

83. Schumacher B, Jung W, Lewalter T, Vahlhaus C, Wolpert C, Lideritz B. Radiom frequency ablation of atrial tutter due to administration of class $I C$ antiarrhythmic drugs for atrial fibrillation. Am J Cardiol 1999;83:710-713.

84. Poty H, Saoudi N, Aziz AA, Nair M, Letac B. Radiofrequency ablation of type I atrial flutter. Prediction of late success by electrophysiological criteria. Ciralation $1995 ; 92: 1389-1392$.

85. Schumacher $B$, P feiffer D, Tebbenjohamns J, Lewalter T, Jung W, Liideriz B. Acute and long-term effects of consecutive radiofrequency applications on conduction properties of the subeustachian isthmus in type I atrial flutrer. I Cardowas Elcorophysiol 1998;9:152-163.

86. Tai CT, Chen SA, Chiang CE, Lee SH, Wen ZC, Huang JL, Chen YJ, Yu WC, Feng AN, Lin YJ, Ding YA, Chang MS. Long-term outcone of radiofrequency catheter ablation for typical atrial flutter: risk prediction of recurrent arrhythmias. J Cardionase Electrophysiol 1998;9:115-121.

87. Phillipon F, Plumb VJ, Epstein A, Kay GN. The risk of atrial fibrillation following radiofrequency catheter ablation of atrial futter. Cirulasion 1995;92:430-435.

88. Paydak H, Kall JG, Burke MC, Rubenstein D, Kopp DE, Verdino RJ, Wilber DJ. Atrial fibrillation after radiofrequency ablation of type [ atrial lutter: time to onset, determinants, and clinical course. Cirwation 1998;98:315-322.

89. Anselme F, Saoudi N, Poty H, Douillet R, Cribier A. Radiofrequency catheter ablation of common atrial futter. Significance of palpitations and quality-of-lift evaluation in patients with proven isthmus block. Circulaion 1999;99:534-540. 
90. Frey B, Kreiner $G$, Binder $T$, Heinz G, Baumgartner H, Gössinger HD. Relation between left atrial size and secondary atriall arrhythmias after successful catheter ablation of common atrial flutter. Paring Clin Electrophysiol 1997;20:2936-2942.

91. Chen TO. Atrial flutter during quinidine therapy of atrial fibrillation. An Hean J 1956;52:273-289.

92. Brugada J, Gürsoy S, Brugada P, Atié J, Guiraudon G, Andries E. Cibenzoline transforms random re-entry into ordered reentry in the atria. Eur Heart $J$ 1993;14:267-272.

93. Saoudi $N$, Atallah Gr, Kirkorian G, Touboul P. Catheter ablation of the atrial myocardium in human type I atrial flutter. Circulation 1990;81:762-771.

94. Feld GK, Fleck RP, Chen PS, Boyce K, Bahnson TD, Stein JB, Calisi CM, Ibarra $M$. Radiofrequency catheter ablation for the treatment of human type I atrial flutter. Identification of a critical zone in the reentrant circuit by endocardial mapping techniques. Circulation 1992;86:1233-1240.

95. Cosio F, López-Gíl M, Goicolea A, Arribas F, Barroso JL. Radiofrequency ablation of the inferior vena cava - tricuspid valve annulus isthmus in common atrial flutter. Am J Cardiol 1993;71:705-709.

96. Kirkorian G, Moncada E, Chevalier P, Canu G, Claudel JP, Bellon C, Lyon L, Touboul P. Radiofrequency ablation of atrial flutter. Efficacy of an anatomically guided approach. Circulation 1994;2804-2814.

97. Calkins H, Leon AR, Deam G, Kalbfleisch SJ, Langberg JJ, Morady F. Catheter ablation of atrial flutter using radiofrequency energy. Am J Cardiol 1994;73:353-356.

98. Fischer B, Haïsaguerre M, Garrigues S, Poquet F, Gencel L, Clémenty J, Marcus F. Radiofrequency catheter ablation of common atrial flutter in 80 patients. I Am Coll Cardiol 1995;25:1365-1372.

99. Steinberg IS, Prasher S, Zelenkofske S, Ehlert FA. Radiofrequency catheter ablation of atrial flutter: procedural success and long-term outcome. Am Heart $J$ $1995 ; 130: 85-92$.

100. Chen SA, Chiang CE, Wu TJ, Tai CT, Lee SH, Cheng CC, Chiou CW, Ueng KC, Wen ZC, Chang MS. Radiofrequency catheter ablation of common atrial flutter: comparison of electrophysiologically guided focal ablation technique and linear ablation technique. J Am Coll Cardiol 1996;27:860-868.

101. Schwartzman D, Callans DJ, Gottlieb CD, Dillon SM, Movsowitz C, Marchlinski FE. Conduction block in the inferior vena cava - tricuspid valve isthmus: association with outcome of radiofrequency ablation of type $\mathbb{I}$ atrial flutter. $J$ Am Coll Cardiol 1996;28:1519-1531.

102. Tai CT, Chen SA, Chiang CE, Lee SH, Ueng KC, Wen ZC, Chen YJ, Yu WC, Huang JL, Chiou CW, Chang MS. Electrophysiologic characteristics and radiofrequency cacheter ablation in patients with clockwise atrial flutter. $J$ Cardiovase Electrophysiol 1997;8:24-34.

103. Shah DC, Haissaguerte M, Jäs P, Fischer B, Takahashi A, Hocini M, Clémenty J. Simplified electrophysiologically directed catheter ablation of recurrent common atrial flutter. Circulation 1997;96:2505-2508. 
104. Epstein LM, Mitchell MA, Smith TW, Hames DW. Comparative study of finoros copy and intracardiac echocardiography guidance for the creation of linear atrial lesions. Cirwlation 1998;98:1796-1801.

105. Avitall B, Helms RW, Chang W, Perinan BA. Non-linear atrial radiofrequency lesions are arthythmogenic: a study of skipped lesions in the nomal atria. Cirwation 1995;92(suppl):1-265. Abstract.

106. Rosenthal LS, Mahesh M, Beck TJ, Saul JP, Miller JM, Kay N, Klein LS, Huang S, Gillette P, Prystowsky E, Carlson M, Berger RD, Lawrence JH, Yong P, Calkins H. Predictors of fluoroscopy time and estimated radiation exposure during radiofrequency catheter ablation procedures. Am J Cardiol 1998;82:451-458.

107. Wahl MR, Cusma JT, Stevens CL, Packer D. Radiation exposure and associated cancer mortality risk due to fuoroscopy in RF catheter ablation of atral fibrillation. Circulation 1998;98(Suppl):I-181. Abstract.

108. Langberg IJ, Gallagher M, Strickberger A, Amirana O. Temperature guided radiofrequency catheter ablation with very large distal electrodes. Circulation $1993 ; 88: 245-249$

109. Otomo K, Yamanashi WS, Tondo C, Antz M, Bussey J, Pitha JV, Arruda M, Nakagawa H, Witkampf FHM, Lazzara R, Jackman WM. Why a large tip electrode makes a deeper radiofrequency lesion: effects of increase in electrode cooling and electrode-tissue interface area. J Cardiovas Electroplysiol 1998;9:47-54.

110. Chugh. SS, Chan RC, Johnson SB, Packer DL. Catheter tip orientation affects radiofrequency ablation size in the canine left ventricle. Pacing Clin Electrophysiol 1999;22:413-420.

111. Iesaka Y, Takahashi A, Goya M, Yamane T, Tokunaga T, Amemiya H, Fijiwara H, Nitta J, Nogami A. Aonuma K, Hiroe M, Marumo F, Hiraoka M. High energy radiofrequency catheter ablation for common atrial futter targeting the isthmus between the inferior vena cava and tricuspid annulus using a super long tip electrode. Pacing Clin Electrophysiol 1998:21:401-409.

112. Jais $\mathrm{P}$, Haissaguerre $M$, Shah DC, Takahashi A. Hocini M, Lavergne "T, Stéphane $L$, Mouroux AL, Fischer B, Clémenty J. Successful irrigated-tip catheter ablation of atrial Autter resistant to conventional radiofrequency ablation. Cinulation 1998:98:835-838.

113. Liem BL, Mead RH. Microwave linear ablation of the isthmus between the inferior vena cava and tricuspid annulus. Pacing Clin Eledrophysiol 1998;21:2079-2086.

114. Anfinsen OG, Kongsgaard E, Foerester A, Aass $H$, Amile JP. Radiofrequency current ablation of porcine right atrium: increased lesion size with bipolar wo catheter technique compared to unipolar application in witro and in wivo. Parmg Clin Electroplysiol 1998; 21:69-78.

115. Barold SS, Shah D, Jais P. Takahashi A, Haissaguere M, Clémenty J. Nomenclature and characterization of transisthmus conduction after ablation of typical atrial fluter. Pacing Clin Electrophysiol 1997;20:175"-1753. 
116. Meca AL, Gou H, Olshansky B. Apparent bidirectional conduction block: not a foolproof marker of success in atrial tlutter ablation. Pacing Clin Electrophysiol 1998:21(Suppl, Part II) 984. Abstract.

117. Arenal A, Almendral J, Alday JM, Villacastín J, Ormaetexe JM, Sande JLM, Perez-Castellano N, Gonzalez S, Ortiz M, Delcan JL. Rate-dependent conduction block of the crista teminalis in patients with typical atrial flutter. Influence on evaluation of cavotricuspid isthmus conduction block. Cirulation 1999:99:2771-2778.

118. Okishige K, Azegami K, Satoh T, Goseki Y, Ohira H, Yamashita K, Satake S. Alternation in the flutter wave morphology during radiofrequency catheter ablation for common atrial flutter. Jpn Cire J 1998;62:795-800.

119. Shah DC, Haissaguerre $M$, Jais $P$, Takahashi A, Hocini $M$, Clémenty J. High-density mapping of activation through an incomplete isthmus ablation line. Circulation 1999;99:211-215.

120. Yamabe $\mathbb{H}$, Okumura K, Misumi I, Fukushima H, Ueno K. Kimura Y, Hokamura $Y$. Role of bipolar electrogram polarity mapping in localizing recurrent conduction in the isthmus early and late after ablation of atrial flutter. $J$ Am Coll Cardiol 1999;33:39-45.

121. Willems $S$, Weiss $C$, Hoffmann M, Meinertz T. Atrial flutter ablation using a technique for detection of conduction block within the posterior isthmus. Pacing Clin Electrophysiol 1999;22:750-758.

122. Nakagawa $\mathrm{H}$, Jackman WM. Use of three-dimensional, non-fluoroscopic mapping system for catheter ablation of typical atrial flutter. Pacing Clin Electrophysiol 1998;21:1279-1286.

123. Goyal R, Zivin A, Souza F, Flemming M, Knight BP, Man KC, Strickberger A, Morady F. Endocardial mapping of typical atrial flutter using a noncontact mapping system. Circulation 1998;98:I-73. Abstract. 


\section{Radiofrequency ablation of "class IC atrial flutter" in patients with resistant atrial fibrillation}

Ashish Nabar, MD; Luz-Maria Rodriguez, MD; Carl Timmermans, MD; Joep L.R.M. Smeets, MD and Hein J.J. Wellens, MD.

Department of Cardiology, Academic Hospital Maastricht.

Abstract presented at the $71^{\text {si }}$ Annual Scientific Sessions of the American Heart Association, 1998

(Circulation 1998;98:1-565)

Published in Am J Cardiol 1999;83:785-787. 


\section{ABSTRACT}

Background: Atrial fibrillation (AF) organizes to atrial flutter (AFL) in 3.5-20\% of patients on class $I C$ antiarthythmic drugs (AAD), the so called "class $/ C$ atrial fiutter". We investigated if radiofrequency ablation (RFA) of "class IC AFL" can modify the "natural" course of Af.

Methods: Fourteen patients (age $=53.7 \pm 13.9$ years 12 males) with daily recurrences of therapy resistant (median $=3$ AADS) $A F$, paroxysmal $(n=8)$ or chronic persistent $(n=6)$, who developed "class IC AFL" (cycle length $=230 \pm 28$ ms) while on propafenone $(n=9)$ or flecainide $(n=5)$ therapy for a median duration of 3 months, underwent RFA of AFL by the anatomical approach. Counterclockwise AFL (2 patients had an additional clockwise AFL) and/or evidence of bidirectional isthmus conduction (BlC) was documented in all patients.

Results: Radiofrequency ablation was successful (AFL non-inducible and BiC block) in 12 patients, partially successful (AFL non inducible but no BIC block) in 1 patient and failed (operated Ebstein's anomaly) in 1 patient. The mean procedure and fluoroscopy time was $191.2 \pm 48.1$ and $49.9 \pm 23.9$ minutes, respectively. All, but 1 patient continued class IC AAD. At a mean follow-up of 4 months (range, 2 to 13 months) following successful RFA ( $n=13$, including 1 partial success), 9 patients are symptom free and 2 patients have had a few (1 and 4 each), short-lasting AF recurrences. Thus 111 of $13(85 \%)$ patients improved clinically after RFA. The last two patients underwent successful repeat RFA for AFL recurrence but later had AF recurrences, albeit less frequent.

Conclusion: In patients with AF who develop AFL during treatment with dass $C$ AADS, REA of the isthmus results in a clinical improvement in $85 \%$ of the patients. A larger prospective study with a longer follow-up is required to validate its benefits. 
Chapter $2 \mid$ "Class IC atrial flutter" ablation for resigtant atrial fibrillation

\section{Introduction}

Class IC antiarrhythmic drugs (AAD) are recommended as the initial therapy in patients with lone atrial fibrillation (AF). In some of these patients, $A F$ converts or recurs as persistent atrial flutter (AFL).2 Radiofrequency ablation (RFA) of typical AFL by the anatomic approach has good procedural ${ }^{3}$ and long term results. ${ }^{4}$ In the present study we evaluated the hypothesis that successful RFA of the right atrial isthmus in patients with resistant AF who develop AFL while receiving class $I C$ AAD therapy could favorably modify the "natural" course of AF.

\section{Methods}

Study patients: Fourteen consecutive patients with drug-resistant AF who developed AFL during treatment with an oral class IC AAD, so called "dass IC atrial flutter" were offered RFA of AFL (Table 1). Inclusion in the study required documentation of typical AFL with negative flutter waves in the inferior leads. The mean patient age was $53.7 \pm 13.9$ years (range 22 to 78 ), and there were 12 men. All the patients had disabling palpitations because of chronic ( 6 patients) or frequently recurring episodes ( 8 patients) of AF. The median duration from symptom onset was 3.5 years (range 1 month to 20 years). The mean left atrial size was $4.6 \pm 0.3 \mathrm{~cm}$. Four patients had mild to moderate mitral regurgitation, 1 tricuspid regurgitation, and 1 decompensated left ventricular function (left ventricular ejection fraction $40 \%$ ) as a consequence of the tachycardia. One patient had a repaired Ebstein's anomaly. Antiarrhythmic drugs (median 3, range 1 to 4) were ineffective in preventing recurrences. Two patients had an implantable Atrioverter (Metrix ${ }^{\mathrm{TM}} 3020$ device, InControl, Redmond, Washington). Patients were treated with either oral propafenone $(450-900 \mathrm{mg} / \mathrm{day}, 9$ patients) or flecainide $(100-300 \mathrm{mg} /$ day, 5 patients) for a median duration of 3 months (range, 2 to 8 ) before transformation to AFL was noted (Figure. 1). One patient with "class IC AFL" receiving flecainide had a collapse due to transient $1: 1$ atrioventricular (AV) response confimed by the episode log of the Atrioverter.

Electrophysiological study and RFA: Electrophysiologic study and RFA was performed after informed, written consent. Class IC AADs were continued. At the time of study, 9 patients were in sinus rhythm and 5 had sustained AFL. The mean flutter cycle length was $230 \pm 28 \mathrm{~ms}$ with a predominant $2: 1 \mathrm{AV}$ response. Counterclockwise AFL was documented in all patients, and 2 patients also had a clockwise AFL. The mean anterograde (lateromedial) and retrograde 


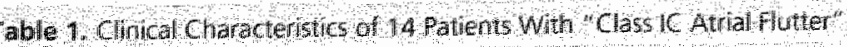

\begin{tabular}{|c|c|c|c|c|c|c|}
\hline Age & sex & TYPSAP & Af duraton & $\begin{array}{l}\text { Additional } \\
\text { Heant Disease }\end{array}$ & $\begin{array}{l}\text { No of } \\
\text { falled } \\
\text { AADs }\end{array}$ & Class ICAADs \\
\hline 22 & M & parosysmal & $3 \mathrm{mo}$ & $\theta$ & 1 & Propafenone $(450)$ \\
\hline 40 & $M$ & persistent & 10 & Repaired & 2 & Flecanide (100) \\
\hline 40 & M & paroxysmal & 1 & & 3 & Hecainide $(100)$ \\
\hline 48 & r & persistent & 3 & Tachycardio- & 2 & Propafenone (450) \\
\hline 51 & $M$ & paroxysmal & 8 & & 2 & Propatenone 450 \\
\hline 51 & $M$ & paroxysnal & 19 & Atrial septal & 1 & Propatencme $(900)$ \\
\hline 53 & $\mathrm{M}$ & & 3 & & 4 & Propafenone (450) \\
\hline 56 & M & paroxymmal & $8 \mathrm{mo}$ & & 1 & Propafenone (900) \\
\hline 5 & $\mathrm{M}$ & parokysmal & 4 & 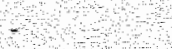 & 2 & Propafenone 450 ) \\
\hline 59 & $M$ & paroxysmal & 1 & & 1 & Flecainide 800$)$ \\
\hline 63 & M & persistent & 17 & & 4 & Flecainide (100) \\
\hline 67 & $\mathrm{P}$ & persistent & 10 & & 2 & Flecainide 1200 \\
\hline 67 & M & persistent & 2 & & 4 & Propafenone (600) \\
\hline 78 & $M$ & paroxysmall & 20 & $\begin{array}{l}\text { Mitra valve } \\
\text { prolapse }\end{array}$ & 4 & Propalenone 900 ) \\
\hline
\end{tabular}

*Palient will Atibuerter

(mediolateral) isthmus conduction times were $98 \pm 25.5 \mathrm{~ms}$ and $61 \pm 26.8 \mathrm{~ms}$ respectively. A 4-mm (Cordis-Webster, Baldwin Park, California) or 8-mm-tip (EP Technology, Mountain View, California; or Cerablate ${ }^{(E)}$ plus Fituter, Osypka, Sulzer Medica, Grenzach-Wyhlen, Germany) ablation catheter, passed through an 8 Fr long sheath (SAFL or SRO, Daig, Minnetonka, Minnesota) was used. Linear ablation of the posterior isthmus was performed, followed by the ablation of the septal isthmus, when necessary. ${ }^{6}$ Procedural success was defined as inability to induce AFL and demonstration of bidirectional isthmus conduction (BlC) block ${ }^{4}$ during isoproterenol infusion ( 1 to $3 \mu \mathrm{g} / \mathrm{min}$ ). Follow-up was conducted at 8 and subsequently at 3 -month intervals. Patients were advised to continue taking propafenone or flecainide. Holter recordings were requested at predischarge, at 8 and 12 weeks after the procedure, and when symptoms suggested an arrhythmia recurrence. The symptom status of all patients was confimed by telephone at the end of the study. 


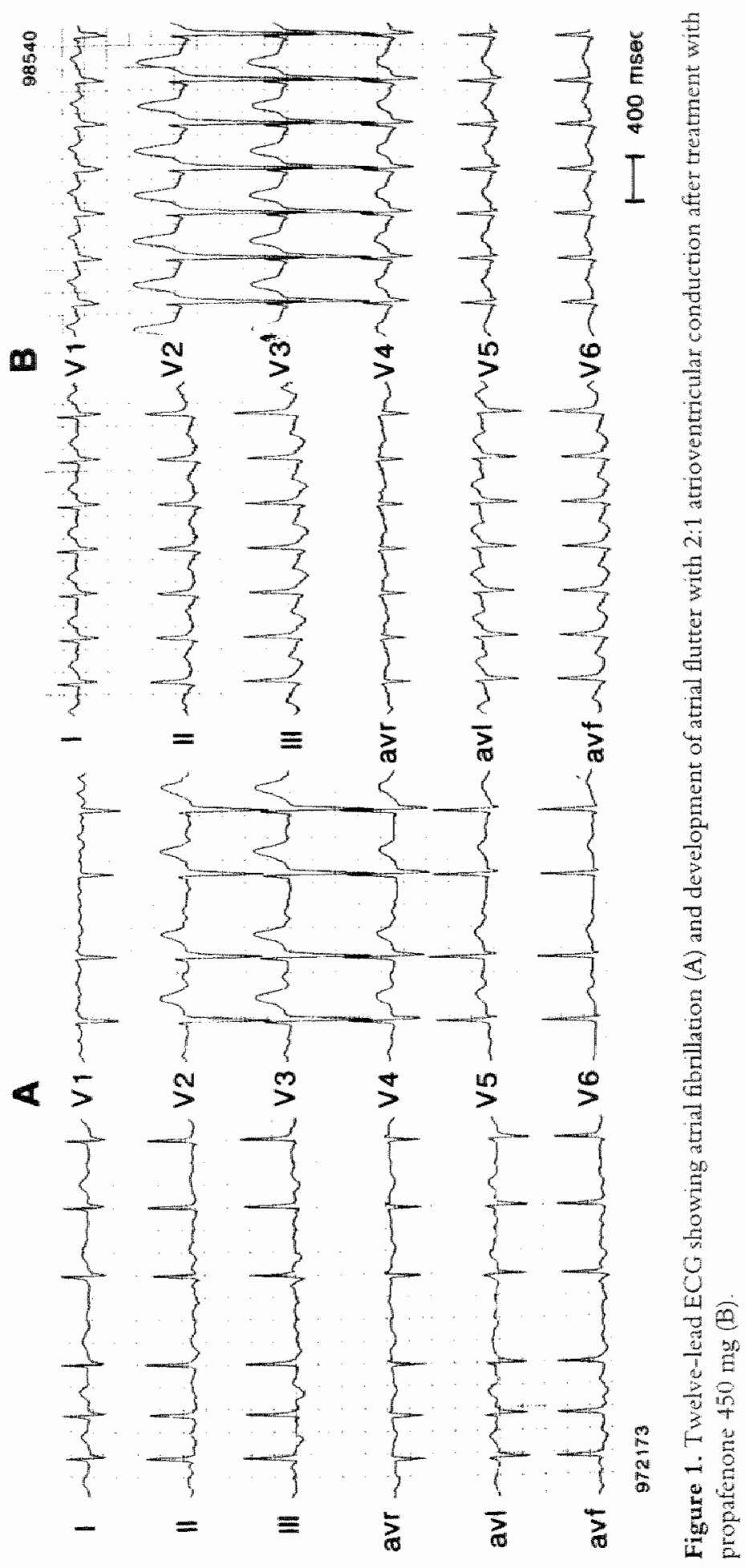




\section{Results}

Six patients had sustained AF during the course of the procedure. Sinus rhythm was restored in all patients by intravenous flecainide $(n=3)$, external cardioversion $(n=1)$ or both $(n=2)$. Procedural success was obtained in 12 of 14 (85\%) patients. The posterior isthmus was ablated in all, with 4 patients requiring additional septal isthmus ablation. One procedure was classified as a partial success, because AFL was noninducible but no BlC block could be demonstrated. A patient with repaired Ebstein's anomaly had an unsuccessful procedure. A median number of 25 applications (range, 12 - 54), each of 90 seconds duration, were required per procedure. The mean procedure and fluoroscopy times were $191.2 \pm 48.1$ and $49.9 \pm 23.9$ minutes, respectively. No patient had in-hospital recurrences. A mean follow-up of 4 months (range, 2 to 13) was available in all 13 patients who had a successful (including 1 partial success) ablation. Nine patients were completely symptom free. Seven of these 9 patients continued taking class IC AADs. One patient also received amiodarone, and flecainide was replaced by atenolol in 1 patient. Two patients had a few ( 1 and 4 each) short-lasting and well-tolerated symptomatic AF episodes during a follow-up period of 1 and 5 months, respectively. None of the 11 patients had recurrence of AFL. The remaining 2 patients had AFL recurrence at 3 and 7 months, respectively. During the second study, resumption of BIC was documented and the posterior isthmus successfully reablated. Both patients reported AF recurrences at subsequent follow-up. Addition of oral sotalol $80 \mathrm{mg} / \mathrm{day}$ resulted in a reduction in symptom frequency ( 2 to 3 short-lasting episodes per week) in 1 patient. The other patient continued to have frequent AF episodes despite adding $200 \mathrm{mg} /$ day aniodarone to the daily propafenone medication.

\section{Discussion}

Class IC AADs affect refractory period duration and conduction velocity of atrial tissue. Depression of conduction velocity by a class IC agent may either prevent reentry by producing complete conduction block or it may facilitate reentry by slowing conduction. Class IC AADs cause a rate-dependent prolongation of the atrial refractory period ${ }^{7-9}$ and suppress excitability. The increase in atrial refractory period counteracts the drug-induced conduction slowing and prolongs the wavelength. 7,8 Atrial fibrillation may change into AFL when the combination of electrophysiologic changes induced by class IC agents either prevents the formation of smaller secondary circuits derived from a large "mother" wave or the class IC agent decreases the number and increases the size 
of multiple smaller reentrant circuits, resulting in a single macroreentrant loop? These effects may result in development of "dass $I C$ AFL" in patients with AF. There is a wide variation (3.5 to 20\%) in the reported incidence ${ }^{2} 10$ of "dass IC AFL", at this point we cannot predict in which patients with AF this may develop. The obvious danger is the development of a fast ventricular rate, because the relative slow atrial rate caused by the class IC agent may be followed by $1: 1$ AV conduction. This was observed in 1 of our patients and stresses the need to be aware of this complication when a patient with $\mathrm{AF}$ becomes more symptomatic when treated with a class IC agent.

Previous studies have pointed out the higher risk of postablation AF recurrences in patients with a history of spontaneous $\mathrm{AF}$, structural heart disease, left ventricular ejection fraction $<50 \%$, higher number of previously failed AADs,

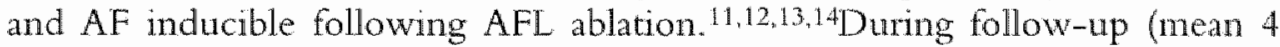
months, range 2 - 13), 9 patients were symptom free and 2 patients had a few, short-lasting and well-tolerated AF recurrences. We may hypothesize that the short-lasting and well-tolerated arrhythmia recurrences in these 2 patients were based on AF, but that the rate-dependent effects of the class IC drug increased the wavelength and the isthmus ablation line caused conduction block, thereby terminating the episode.

\section{Conclusions}

We conclude that, in this small series of patients, there was clinical improvement in 11 of 13 patients (85\%) after combined class IC AAD and right atrial isthmus ablation. Similar results were reported recently by Huang at al ${ }^{15}$; however, most of these patients developed AFL when amiodarone was prescribed for the treatment of $\mathrm{AF}$. This suggests that these changes also may occur when patients are receiving drugs other than class $\mathrm{IC}$ agents and stresses the need to carefully evaluate the behaviour of AF after drug administration. The incidence of long-term success of right atrial isthmus ablation in patients who develop AFL requires further study.

\section{References}

1. Pratt CM. Impact of managed care on the treatment of atrial fibrillation. Am J Cardiol 1998;81(5A):30C-34C. 
2. Falk RH. Proarhythmic responses to atrial antiarthythmic therapy. In: Falk RH and Podrid PJ, eds. Atrial fibrillation: Mechanisms and Management. New York: Raven Press Ltd. 1992:283-305.

3. Cosio FG, López-Gill M, Goicolea A. Arribas F, Barroso JL. Radiofrequency ablation of the inferior vena cava-tricuspid annulus valve isthmus in common atrial Autter. Am J Cardiol 1993,71:705-709.

4. Poty H, Saoudi N, Aziz AA. Nair M, Letac B. Radiofrequency catheter ablation of type I atrial futter. Prediction of late success by electrophysiological criteria. Ciruld tion $1995 ; 92: 1389-1392$

5. Canchemez $\mathbb{B}$, Harssaguere $M$, Fischer $B$, Thomas $O$, Clémenty $J$, Coumel $P$. Electrophysiological effects of catheter ablation of inferior vena cava-tricuspid annulus isthmus in common atrial futter. Citculation 1996:93:284-294.

6. Nakagawa $\mathbb{H}$, Lazzara $\mathbb{R}$, Khastigit $T$, Beckman KJ, McClelland JH, Imai S, Pitha JV, Becker AE, Arruda M, Gonzalez MD, Widman LE, Rome M, Neuhauser J, Wang X, Calame JD, Goudeau MD, Jackman WM. Role of tricuspid annulus and. eustachian valve/ridge on atrial flutter. Relevance to catheter ablation of the septal isthmus and a new technique for rapid idencification of ablation success. Circulation $1996,94: 407-424$

7. Crijns HJGM. Clinical manifestations of use- and reverse-use dependence. In: Crijns HJGM, ed. Changes of intracardiac conduction induced by antiarthythmic drugs: Importance of use- and reverse use-dependence. Groningen, Netherlands: BV Knoop Haren; 1993:38-105.

8. O'Hara G, Villemarie C. Talajic M, Nattel S. Efects of flecainide on the rate dependency of atrial refiactoriness, atrial repolarization and atrioventricular nodal conduction in anesthetized dogs. I Am Coll Cardiol 1992;19:1335-1342.

9. Allessie MA, Janse MJ. Mechanisms of atrial arthythmias. In: Singh BN, Wellens HJJ, Hiroka M, eds. Electrophamacological control of cardiac arthythmias. Mount

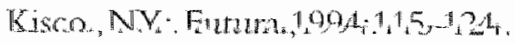

10. Feld GK, Chen PS, Nicod P, Fleck RP, Mezer D. Atrial proarthythmic effects of class $\llbracket \mathrm{C}$ anciarthythmic drugs. Am J Cardiol 1990;66:378-383.

11. Philippon F. Phumb VJ, Epstein AE, Neal Kay G. The risk of atrial fibrillation following madiofrequency catheter ablation of atrial flutter. Cimalonion $1995: 92: 430-435$

12. Movsowitz C, Callans DJ, Schwartzman D, Gottieb C, Marchlinski FE. The results of atrial fluter ablation in patients with and without a history of atrial fibrillation. Am ICardiol 1996;78:93-96.

13. Tui CT, Chen SA, Chang CE, Lee SH, Wen ZC, Huang JL, Chea YJ, Yu WC, Feng AN, Lin YJ, Ding YA, Chang MS. Long-tern outcome of radiofrequency cathcter ablation for typical atrial futter: risk prediction of recurrent arrhythmias. I Cardiovas Elcoroplysiol 1998;9:115-121.

14. Paydak H, Kall JG, Burke MC, Rubenstein D, Kopp DE, Verdino RJ, Wiber DJ. Atrial fibrilation aftar radiofrequency ablation of atrial futter. Time to onset, determinants, and clinical course. Cirmation 1998,98:315-322. 
15. Huang DT, Monahan KM, Zimetbaum P. Papageorgiou P, Epstein LM, Josephron ME. Hybrid pharmacologic and blative therapy: a novel and efrective approacth for the management of atrial fibrillation. J Candion Elctrophysiol 1998:9.462-469. 

Effect of right atrial isthmus ablation on the occurrence of atrial fibrillation:

Observations in four patient groups having type I atrial flutter with or without associated atrial fibrillation

Ashish Nabar, MD; Luz-Maria Rodriguez, MD; Carl Timmermans, MD; Adri van den Dool, RN; Joep L.R.M. Smeets, MD and Hein J.J. Wellens, MD. Department of Cardiology, Academic Hospital Maastricht. 


\section{ABSTRACT}

Objective: The goal of this study was to test the hypothesis that the occurrence of atrial fibrilation (AF) in at least some patients with coexisting type atrial flutter (AFL), is based on macro-reentry around the tricuspid valve orifice including the right atrial (RA) isthmus, by evaluation of AF recurrences following successful ablation of AFI.

Methods: Eighty-two consecutive patients with type I AFL, with or without concomitant AF, underwent radiofrequency ablation (RFA) of the RA isthmus by an anatomical approach. The results were analyzed in 4 groups of patients: group 1 Conly AFL; 29 patients), group 2 (AFL > AF; 22 patients), group 3 (AF > AFL; 15 patients) and group 4 (developing AFL while receiving class $K$ antiarhythmic drug therapy for $A F$, the "class $K$ atrial flutter"; 16 patients).

Results: Im all groups, RFA of type I AFL was performed with a high $\geq 93 \%$ ) procedural success rate. In group 1, only $2(8 \%)$ patients had AF after (18 \pm 14 months) AFL ablation. These igures were $38 \%(20 \pm 14$ months) and $86 \%(13 \pm 8$ months) in groups 2 and 3 , respectively. Group 4 patients ( $4 \pm 2$ months) had a $73 \%$ freedom of AF racurences with continuation of the class $I C$ agent.

Conclusions: The low incidence of new AF during long-term follow-up after RFA of lype / AFL makes it unlikely that radiofrequency lesions promote the development of Af. The impact of isthmus ablation on AF recurrences differs according to the cinically predominan atrial arrythmia and suggests a possible role of the RA isthrnus in the occurrence of AF in some patients. Ablation of class IC AFL in patients witm therapy-resistant AF is a novel approach to management of this patient subset. Careful classification of Af patients plays a role in the selection of the site of ablation therapy. 


\section{Introduction}

Atrial flutter (AFL) and atrial fibrillation (AF), which are both intra-atrial reentrant arrhythmias with differing complexity in their activation pattern and mechanisms, are frequently seen to coexist in clinical practice. Long-term success of radiofrequency ablation (RFA) of AFL may be undone by the occurrence of $A F$, either preexisting or developing de novo. Few studies have evaluated the incidence of AF after successful RFA of type I AFL. $1-3$ We evaluated the hypothesis that at least in some patients with coexisting type I AFL, maintenance of AF might be based on macro-reentry around the tricuspid valve orifice, including the right atrial (RA) isthmus. We therefore evaluated the long-term occurrence of AF following a successful RFA of the RA isthmus for type I AFL.

\section{Methods}

Study population: Eighty-two consecutive patients with type $\mathbb{A F L}$, identified by negative flutter waves in the inferior leads and positive flutter waves in lead V1, ${ }^{4}$ who underwent RFA of the RA isthmus by an anatomical approach were included. All procedures were performed between November 1994 and April 1998. Patients having documentation of additional episodes of AF were also considered for RFA. The patient population was divided into 4 groups after careful review of the available ECGs and 24-hour Holter recordings. Group 1 consisted of patients who had documented episodes of AFL alone. Patients included in group 2 predominantly had episodes of AFL and 1 to 3 isolated episodes of AF; thus, AFL as their most frequently occurring arrhythmia. Paticnts included in group 3 had predominant documentation of AF. In these patients, 1 or 2 episodes of AFL were detected. Patients with therapy-resistant AF and no previous documentation of AFL but who developed AFL on oral class $I C$ antiarrhythmic drug (AAD) (propafenone or flecainide) were placed in group 4. We called this new AFL the "class IC atrial flutter". After a median trentment duration of 3 months (range, $2-8$ months) class IC AFL occurred. The characteristics of the 82 patients are summarized in Table 1 . Every patient was symptomatic with intermittent palpitations despite AAD therapy. Coronary artery disease was the most common structural heart disease amongst patients in groups $1(\mathrm{n}=14), 2(\mathrm{n}=3)$ and $3(\mathrm{n}=2)$ and was considered an exclusion criterion for patients in group 4 . Tachycardiomyopathy was diagnosed in 3 patients in group 1,2 patients in group 3 and 1 patient each in groups 2 and 4 . Six patients had previously undergone coronary bypass surgery ( 1 in group 1,2 in group 2 and 3 in group 3), whereas repair of atrial septal defect (group I) and Ebstein's anonaly 


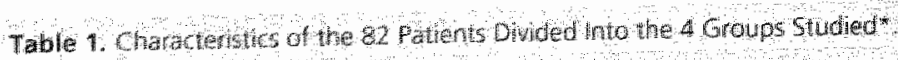

\begin{tabular}{|c|c|c|c|c|}
\hline Grougl & GHOUEL & 61040 & $6 \cos 4$ & $P$ \\
\hline $4 n+2$ & $n=2)$ & $n-1 s$ & $(n=16)$ & \\
\hline $605+15 s$ & $550=164$ & $508=157$ & $531+139$ & NS \\
\hline 245 & $2 \pi / 1$ & $13 / 2$ & 14 & $\mathrm{NS}$ \\
\hline $16(62)$ & $5(23)$ & 427 & 2113 & 0,002 \\
\hline $34 \mathrm{mmo} 0 \mathrm{al}$ & 5 sk $60 m 000 y$ & $5 y(4 m o-13 y)$ & $3.5 y 11 m o l 0 y$ & \\
\hline $24-6)$ & 3417 & 35189 & $3 \mid(-4)$ & \\
\hline $44+05$ & 47,08 & $42+04$ & $46+03$ & 0,09 \\
\hline 9 & 2 & 3 & 1 & NS \\
\hline & 220 & 60 & 818 & \\
\hline
\end{tabular}

(group 4) was performed in 1 patient each. Fifeen patients (9 in group 1, 2 in group 2,3 in group 3 and 1 in group 4) had a left ventricular ejection fraction. (LVEF) $<50 \%$. Compared with patients in other groups, patients in group 1 had a higher incidence $(P=0.002)$ of structural heart disease, whereas patients included in group 2 had a larger $(P=0.04)$ mean left atrial size. Devices implanted before ablation included a pacemaker $(n=4,2$ each in group 1 and 3$)$ and an Atrioverter (Metrix TM 3020 device, InControl; $n=3: 1$ in group 3 and 2 in group 4).5 All patients in group 2 had paroxysmal AF, whereas a greater ( 9 of 15) or an equal ( 8 of 16) proportion of patients in groups 3 and 4 , respectively, had chronic persistent AF.

Electrophysiology study and RFA: Infomed writen consent was obtained. In patients with frequent anthythmia recurrences, AADs were contuned. Bidirectional isthnus conduction (BIC) and collision of dual wave frones was demonstrated, and programmed atrial stimulation was performed to induce AFL. Anatomically guided linear ablation of the $R A$ isthmus was perfomed?-46-16 using either Amm-tip (Cordis Webster) or an 8 mm-tip (EP Technology or Cerablate phs Fluter, Osypka, Sulzer Medica) ablation catheter sabilized through an 8Fr long sheath (SAFL or SR0, Daig Corp.). Radiofrequency pulses were delvered with the temperature preset to $55^{\circ} \mathrm{C}$ (Osypka HAT $300 \mathrm{~s})$ or $70^{\circ} \mathrm{C}$ (Stockent $\mathrm{Gmbh}$ ) for 90 seconds. Ablation of the posterior and/on septat inthm was performed. Initially, noninducibility of AFL 2.7-9 was considwred a procedural success. Later, we sought to achieve isthmus conduction block, intially undirectional (confumed by cononary sinus [CS] pacing) and currenty

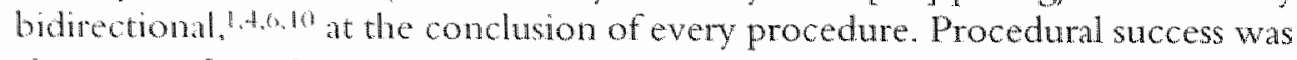
alway contimed under isoproterenol intusion ( 1 to $3 \mu \mathrm{g} / \mathrm{min}$ ). A 24 hour Holter recording was made before discharge. At follow-up, patients in group 1 
discontinued AADs, and patients in groups 2 and 3 received AAD therapy to prevent AF recurrences. Patients in group IV continued either propafenone or flecainide. If the first procedure was not successful, repeat REA was advised.

Follow-up: Follow-up was conducted at the arrhythmia clinic, initialy at 8 weeks and subsequently at 3-month intervals. Patients with successful RFA of AFL were eligible for follow-up analysis. Holter recordings were nade at 8 and 12 weeks and when symptoms were suggestive of an arrythmia recumence. Patients with a documented AFL recurrence underwent repeated RFA. Patients with recurrent $A F$ were managed with $A A D$ s and/or by nonpharmacological alternatives. Current symptom status of all patients was confimed by telephone.

Statistical analysis: Results are expressed as mean \pm S.D, median and range. Mean values were compared by 1 -way ANOVA, and the $\chi^{2}$ test for Fisher's exact test) was used for testing homogeneity in contingency tables. Results were considered to be significant at the $5 \%$ critical level $(P<0.05)$.

\section{Results}

Electrophysiology study and RFA procedure: The results of electrophysiology study and RFA procedures in the 82 patients are summarized in Table 2. During the electrophysiology study, more patients in group $1(P=$ 0.01) presented with incessant AFL. One patient in group 1 and 3 patients in group 2 were successully ablated after a second procedure. A second attempt Gailed to ablate AFL in 1 patient (group 3). The mean AFL cycle length in the 4 groups varied from $230 \pm 28 \mathrm{~ms}$ to $257 \pm 37 \mathrm{~ms}$. Predominantly, a counterclockwise AFL was induced in all 4 groups. More ablation procedures were perfomed during CS pacing in patients from groups 1 through 4, whereas a preference for ablation performed during AFL was noted from groups 4 through $1(P=0.003)$. Although statistically not significant, posterior $R A$ isthmus was found to be most frequently ablated in the 4 study groups. However a relatively greater percentage of patients in groups 2 through 4 required additional septal istmmus ablation. Successful RFA could be performed in $293 \%$ patients $(93 \%$ in group $1,96 \%$ in group 2, 93\% in group 3 and $94 \%$ in group 4). A higher $(P=0,02)$ mean number of radiofrequency pulses per successful procedure was required in group 4 patients ( $27 \pm 13$ ) and was related to achieving a BIC block in all successful procedures but $1(P=0.001)$. One patient (group 3) developed complete atrioventricular (AV) block during septal isthmus ablation and needed a pacemaker. This patient had BIC block and AFL noninducibility after the last RF pulse and was classified as a successful ablation. 


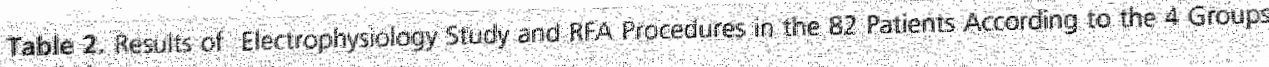
studied

\begin{tabular}{lllll}
\hline \\
\hline
\end{tabular}

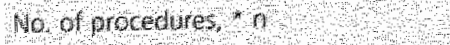

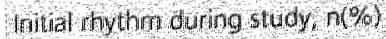

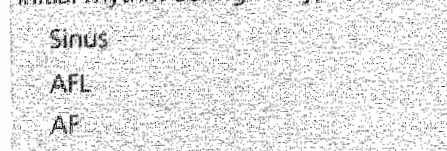

Al onctengh, ns

$251+37$

$25+37$

$239+28$

$20+28$

N5

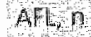

nowed (ccmsn)

$25(21 / 5$

19,176

31112

$161102)$

Nonnduced

4

3

4

0

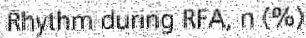

\section{rspocing}

Al:

SPadintall

DA isthrnus ablared $\mathrm{n}(\mathrm{c})$

poslentor

Sepol

postelor + septal

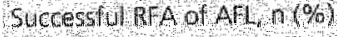

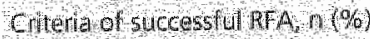

NE

$N+10$ loloc

NHAB $\mathrm{BlOKK}$
$4(3)$

2214

$4(13)$

$20(6 \pi)$

$3(19)$

$7(2)$

$2729(99)$

$$
4(15)
$$

$15(5)$

8130

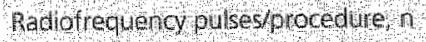

procedure whe nin

moroscopr line, nin

\section{8}

16214

43,28
$8(32)$

$11(44)$

$6(24)$

$14(56)$

$3(2)$

$3(32)$

$21 / 22,96)$

$7(44)$

$11(69)$

0,003

$6(3)$

$3(19)$

$8(50)$

$16)$

$7(44)$

$14 / 5(93)$

$6(29)$

$6(29$

$9(4)$

2214

$199+53$

50,26
3,215

$8(57)$

$3(215)$

$21+10$

$189+10$

$36+14$
50

0

$(163)$

ns

0

$6 / 27$

$15 / 16 / 94) \mathrm{NS}$

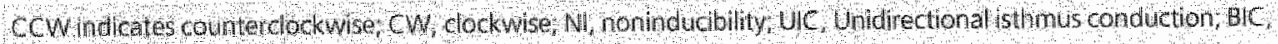

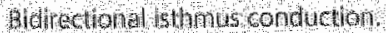

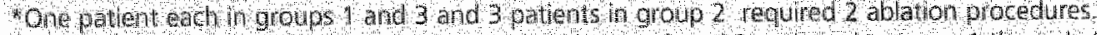

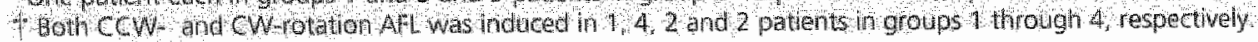

Recurrence of AFL: Follow-up was avalable in all but one patient $(\mathrm{n}=76)$ after successful RFA of AFL (Table 3). Nine patients (12\%) developed an AFL recurrence. No differences were noted $(P=N S)$ in the recurrence rate of $A F L$ in the 4 groups, and all AFL recurrences except 1 occurred within 6 months of ablation. In 7 patients, a recurrence after successful ablation judged by either non inducibility ( $\mathrm{n}=2$ patients) or noninducibility and unidirectional isthmus conduction block ( $\mathrm{n}=5$ patients). In the latter 5 patients, there was a demonstrable isthmus conduction delay, indicating regression of isthmus conduction 


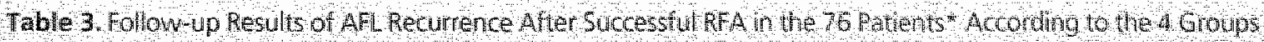
studued

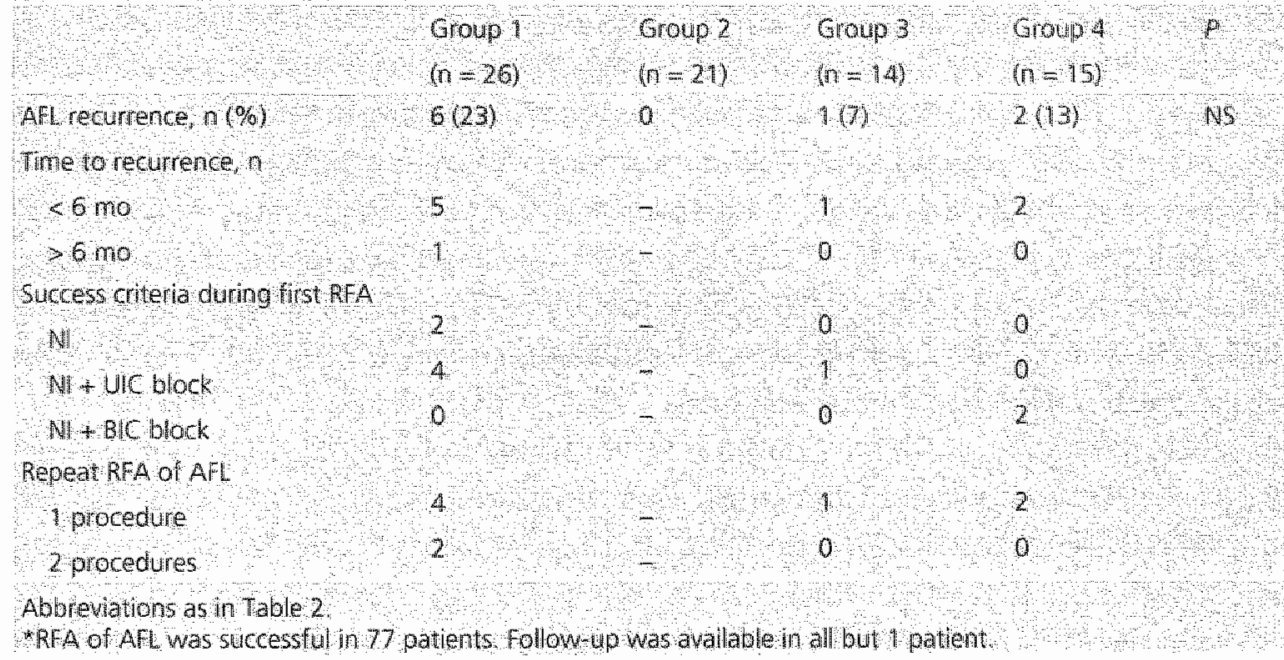

block ( $\mathrm{n}=2$ patients) or resumption of isthmus conduction ( $\mathrm{n}=3$ patients). The remaining 2 patients with BIC block had resumption of isthmus conduction bidirectionally. After a repeated RFA requiring either $1(n=7)$ or $2(n=2)$ sessions, all patients are free of AFL recurrences at the long term.

Atrial fibrillation following RFA of type I AFL: The mean follow-up duration was as follows: group $1,18 \pm 14$ months; $2,20 \pm 14$ months; and $3,13 \pm$ 8 months. Patients in group 4 had a significantly $(P<0.001)$ shorter mean follow-up ( $4 \pm 2$ months). Two patients in group 1 had episodes of paroxysmal AF during the postoperative period after coronary bypass surgery. No other patient in this group developed AF. In group 2, 13 of $21(62 \%)$ patients, including 10 patients in whom AADs were discontinued, were free of AF recurrences. Furthermore, in 5 patients (24\%), AF recurrences were controlled better with AADs that previously failed. Thus, $86 \%$ patients in group 2 had long-term improvement of concomitant AF. The remaining 3 patients had frequent AF recurrences resistant to multiple $A A D$ s. One patient underwent $A V$ nodal ablar tion with pacemaker implantation, another had a surgical Maze procedure, while the third continues to be symptomatic despite AADs. In contrast, only 2 (14\%) patients in group 3 were free of AF recurrences after withdrawal of AAD treatment. In 6 patients (43\%), control of AF was achieved by an AD that had failed before the ablation. This means that $57 \%$ of patients in this group had easier control of AF recurrences after RFA of AFL. The remaining 6 patients remained symptomatic despite trials with different $A A D s$ s $n=4$ patients) and non phamacological methods ( $\mathrm{n}=2$ patients). After successful RFA of class IC AFL and 
continuation of propafenone or flecainide, 11 patients (73\%) in group 4 had no AF recurrences. Two patients had few short-lasting and well-tolerated AF recurrences confirmed by the episode log of the Atrioverter. Thus, at a short-term follow-up, definite improvement occurred in $87 \%$ patients. When the 4 groups were compared for incidence of AF recurrences following RFA of AFL, patients in group 1 had significantly $(P<0.01)$ less risk of AF recurrences.

Follow-up was available in all but one patient from group 1 in the subgroup of 15 patients with LVEF $<50 \%$. Three patients $(0$ in group 1 and 4,1 in group 2 and 2 in group 3) had AF recurrences. In comparison, 23 of $62(37 \%)$ patients with $L V E F \geq 50 \%$ had an $A F$ recurrence $(P=0.13)$.

\section{Discussion}

The study population consisted of 82 consecutive patients who underwent linear ablation of RA isthmus for type I AFL. Both the ablation protocol and the criteria of procedural success evolved during the study period between November 1994 to April 1998. As shown by the longer duration of mean follow-up a greater number of patients in groups 1 (AFL, no AF) and 2 (AFL > AF) were considered for RFA during our early experience. More patients in groups $3(\mathrm{AF}>\mathrm{AFL}$ ) and 4 (class IC AFL) were offered an RFA procedure later; hence, a shorter mean follow-up was available.

Anatomically guided RFA of type I AFL: High procedural success rates $(86 \%$ to $98 \%)$ have been reported after RA isthmus ablation for type I AFL. $1-4,6-10$ In the present study, RFA of AFL was successful in $\geq 93 \%$ of patients in all 4 groups. Initially, ablation procedures were performed during AFL, and non inducibility $2.7-9$ was accepted as a procedural success. Later, following the introduction of isthmus conduction block as a criterion, ablation procedures were performed during sinus rhythm with CS pacing. Therefore, in the present study, there was an increasing use of ablation procedures being performed during CS pacing from groups 1 through 4 . This change in ablation protocol was related to later recruitment of patients in groups 3 and 4 . In all groups, procedural success was more frequent after ablation of the posterior isthmus $(50 \%$ to $67 \%)$ compared with septal isthmus ablation alone $(\leq 10 \%)$. This may relate to the ease of achieving a stable catheter position at the posterior isthmus. Interestingly, a greater proportion of patients in groups 2 through 4, involving patients with concomitant AF, underwent an additional septal isthmus ablation. A potential benefit of ablating the septal isthmus in patients with concomitant AF could be modification of the posterior AV nodal input, " resulting in better ventricular rate control and therefore better tolerance of AF recurrences. During ablation of the 
septal isthmus, 1 patient developed complete AV block and required a pacemaker. Single cases of this complication have been reported. ${ }^{10}$ It indicates the small but definite risk of RFA of the septal isthmus.

Recurrence of AFL: Nine out of 76 patients (12\%) had a recurrence of AFL. Most recurrences $(n=7)$ were in patients in whom noninducibility alone or noninducibility and a unidirectional isthmus conduction block was considered as a success. Higher recurrences $(10 \%$ to $55 \%)$ have been reported after noninducibility alone as a criterion for successful ablation..$^{2.7-9}$ The recurrence rates are lower (6 to $9 \%$ ) in patients with complete BIC block compared with patients with a unidirectional isthmus conduction block or BIC delay at the conclusion of a successful ablation. ${ }^{1,4,6,10}$ All but 1 recurrence of AFL occurred within initial 6 months after ablation. This stresses the need for close follow-up in the months immediately after a successful ablation. Regression ( $n=2$ patients) or complete disappearance ( $n=5$ patients) of isthmus conduction block was demonstrated during a repeat study, as previously reported. ${ }^{16.10}$ Recently, a complete line of double potentials has been advocated as a new success criterion to avoid misinterpretation of isthmus conduction delay as block. ${ }^{2}$ A successful repeated RFA in all 9 patients resulted in long-term freedom from arrhythmia recurrences.

Outcome of AF following successful RFA of type I AFL: A variable number ( $8 \%$ to $30 \%$ ) of patients have been reported to develop AF following RFA of AFL $2,3,8,9$ In group 1, only 2 patients developed AF, both during the postoperative course of coronary bypass surgery. This finding does not support that in patients with AFL, an RA isthmus radiofrequency lesion could be proarrhythmic for the development of AF.

On the basis of our current understanding, at least 3 mechanisms could be responsible for clinical coexistence of type I AFL and AF in patients included in groups 2 and 3: (1) RA leading circle re-entry (type $\mathbb{A F L}$ ) with atrial dissocintion and $A F$ in the left atrium, ${ }^{13}$ (2) RA leading circle re-entry (type I AFL) which becomes unstable and degenerates into multiple wavelets of AF; 14 or (3) temporal dissociation of AFL and AF, with a tendency for significant periods of organization along the trabeculated $\mathrm{RA}$ in a craniocaudal direction during $\mathrm{AF} .{ }^{15}$ During the first 2 mechanisms, AF is secondary to a type I AFL circuit and consequently should cease after RA isthmus ablation, which interrupts the flutter circuit. In AF resulting from the third mechanism, we may speculate, that $\geq 1$ wavefronts propagating along the trabeculated RA would extinguish on encountering the RA isthmus ablation line. This may reduce the critical number of wavelets necessary to sustain AF, which then terminates. The extent of "organization" in paroxysmal versus chronic AF is controversial. 15,16 The chance of reducing or eliminating AF recurrences after ablation of type $1 \mathrm{AFL}$ is greater in patients with the initial 2 
mechanisms as the basis for atrial arrhythmias and less in case of the third mechanism. Radiofrequency ablation of the RA isthmus for type I AFL in combination with a previously ineffective $A A D$ therapy was found to result in longer arrhythmia free interyals in a greater proportion of patients (86\%) in group 2 $(\mathrm{AFL}>\mathrm{AF})$ as compared with group $3(57 \%)$ (AF $>$ AFL). From the above reasoning, it is attractive to postulate that a greater proportion of patients in group 2 had coexisting AFL and AF mediated via the first two mechanisms and consequently derived a larger clinical benefit. Undoubtedly, the electrophysiological basis of the inter-relation between AF and AFL needs further elucidation. On the other hand, the explanation for our data may be simple because ablation of the RA isthmus interrupts a major pathway for impulse conduction between the left and RA. This may affect the ability of AF to remain sustained. In summary, what seems certain is the fact that the chance of lowering AF recurrences appears definitely higher in the subgroup of patients with AFL as their predominant clinical arrhythmia.

Patients included in group 4 (class IC AFL) had AF that was nonresponsive to multiple AADs. Rate-dependent prolongation of atrial refractory period by class $1 \mathrm{C}$ agents effected an increase in the wavelength and facilitated the conversion of AF (multiple smaller reentry circuits) to AFL (a single macro-reentrant loop). ${ }^{7}$ After a RA isthmus ablation and continuation of class IC therapy, $87 \%$ of patients were either symptom free or had only short lasting, well controlled AF recurrences. A similar successful "hybrid" therapy in patients who were treated primarily with amiodarone for AF was recently reported by Huang et al. ${ }^{18}$

A small subgroup $(\mathrm{n}=15,18.2 \%)$ of our patients had LVEF $<50 \%$. Following AFL ablation, 3 of 14 patients (in 1 patient, we have no follow-up) had AF recurrences. Paydak et al, found that a history of spontaneous AF and LVEF $<50 \%$ were significant independent predictors of subsequent AF after AFL ablation. When both characteristics were present, $74 \%$ of their patients had AF recurrences. ${ }^{3}$

\section{Study Limitations}

Our study population was classified into 4 groups on the basis of documentation of AFL alone or in combination with AF. The exact incidence of arrhythmia episodes, especially those that were asymptomatic, is not known and may have affected our classification. Although every procedure involved an RA isthmus ablation, the ablation protocol and the criteria for procedural success have changed over the study period in keeping with advances in our knowledge. A complete isthmus conduction block at the conclusion of a successful procedure 
was not obtained in all patients. This has obvious implications for analysis of arrhythmia recarrences.

\section{Conclusions}

Radiofrequency ablation of type I AFL can be performed, regardless of concomitant AF, with a high primary success rate and low overal] AFL recurrences. A low incidence of new AF after RFA of type I AFL indicates that those radiofrequency lesions do not or rarely lead to development of AF. In patients with type I AFL as their predominant clinical arrhythmia, RA isthmus ablation reduces recurrences of $A F$ over a long period of follow-up. This procedure is less successful in patients with AFL and more frequent episodes of AF. Patients with therapy-resistant AF who develop a type I AFL while receiving class IC therapy also seem to profit, showing a reduced incidence of AF recurrences after AFL ablation. Our findings contribute to the growing conviction to individualize the site and extent of RFA(s) in patients with AF. ${ }^{16,1^{19}}$ Our ultimate goal in RFA for AF should be to apply the interventions only to the site (s) resulting in the greatest amount of success and the least amount of damage to atrial function.

\section{References}

1. Tai CT, Chen SA, Chiang CE, Lee SH, Wen ZC, Huang JL, Chen YJ, Yu WC, Feng AN, Lin YJ, Ding YA, Chang MS. Long-term outcome of radiofreguency catheter ablation for typical atrial thutter: risk prediction of recurrent arrhythmias. J Cardionasc Electrophysiol 1998:9:115-121.

2. Philippon F, Plumb VJ. Epstein A, Kay GN. The risk of atrial fibrillation following radiofrequency catheter ablation of atrial flutter. Circulation 1995;92:430-435.

3. Paydak H, Kall JG, Burke MC, Rubenstein D, Kopp DE, Verdino RJ, Wilber DJ. Atrial fibrillation after radiofrequency ablation of type I atrial flutter: time to onset, determinants, and dinical course. Circulation 1998:98:315-322.

4. Pory H, Saoudi N, Nair M, Anselme F, Letac B. Radiofrequency catheter ablation of atrial flutter: further insights into the various types of isthmus block: application to ablation during sinus rhythm. Circulation 1996;94:3204-3213.

5. Wellens HJJ, Lau CP, Lüdertz B, Akhtar M, Waldo AL, Camm AJ, Timmermans C, Tse HF, Jung W, Jordaens L, Ayers $G$, for the Metrix Investigators. The atrioverter: an implantable device for trearment of atrial fibrillation. Circtation 1998; 98:1651-1656.

6. Poty H, Saoudi N, Aziz AA, Nair M, Letac B. Radiofrequency catheter ablation of type 1 atrial flutrer: prediction of late success by electrophysiological criteria. Circulat tion 1995;92:1389-1392. 
7. Cosio FG, López-Gil M, Goicolea A, Arribas F, Barroso JL. Radiofrequency ablattion of the inferior vena cava- tricuspid valve isthmus in common atrial flutter. Am J Cardiol 1993;71:705-709.

8. Kirkonian G, Moncada E, Chevalier P, Canu G, Claudel JP, Bellon C, Lyon L, Touboul P. Radiofrequency ablation of atrial flutter: efficacy of an anatomically guided approach. Circulation 1994;90:2804-2814.

9. Fischer B, Haissaguerre M, Garrigues S, Poquet F, Gencel L, Clémenty J, Marcus FI. Radiofrequency catheter ablation of common atrial flutter in 80 patients. $J$ Am Coll Cardiol 1995;25:1365-1372.

10. Schumacher B, Pfeiffer D, Tebbenjohanns J, Lewalter $T$, Jung W, Lüderitz B. Acute and long-term effects of consecutive radiofrequency applications on conduction properties of the subeustachian isthmus in type I atrial flutter. $J$ Cardiovase Elecrophysiol 1998;9:152-163.

11. Klug D, Lacroix D, Franc LP, Kouakan C, d'Hautefeuille, Dennetierre S, Pecheux M. Kacet $S$. Linear ischmus block for atrial flutter radiofrequency ablation modifies AV nodal inputs during low lateral atrial pacing. Pacing Clin Electrophysiol 1998; 21 (Part II): 833.Abstract.

12. Shah DC, Takahashi A, Haisaguerre $M$, Jäs $P$, Clémenty J. Definitive criteria of cavo-tricuspicl isthmus block. Pating Clin Electrophysiol 1998;21:832.Abstract.

13. Yamauchi S, Boineau JP, Schuessler RB, Cox JL. Varying types of circus movement reentry with both normal and dissociated contralateral conduction causing different right and left atrial rhythms in canine atrial flutter. Jpn Circ J 1998;62:201-210.

14. Wu TJ, Yashima M, Huang H-LA, Kim YH, Athill CA, Karaguezian HS, Chen PS. Atrial wavefront instability induced by progressive action potential duration shortening: a mechanism of conversion from atrial flutter to atrial fibrillation. $J \mathrm{Am} C \mathrm{Coll}$ Cardiol 1998; Suppl 31(2):158A.Abstract.

15. Roithinger FX, SippensGroenewegen A, Karch MR, Steiner PR, Ellis WS, Lesh $M$. Organized activation during atrial fibrillation in man: endocardial and clectrocardiographic manifestations. J Cardionase Electrophysiol 1998;9:451-461.

16. Gaita F, Riccardi R, Calò L, Scaglione M, Garberoglio L, Antolini R, Kirchner M, Lamberti F, Richiardi E. Atrial mapping and radiofrequency catheter ablation in patients with idiopathic atrial fibrillation: electrophysiolgical findings and ablation results. Cinculation 1998;97:2136-2145

17. Crijns HJGM. Clinical manifestations of use- and reverse-use dependence. In: Crijns HJGM, ed: Changes of intracardiac conduction induced by antiarrhythmic arugs: Importance of use- and reverse-use dependence. Groningen, Netherlands: BV Knoop Haren; 1993:38-105.

18. Huang DT, Monahan KM. Zimetbaum P. Papageorgiou P, Epstein LM, Josephson ME. Hybrid phamacologic and ablative therapy: a novel and effective approach for the management of atrial fibrillation. J Cardiovase Electrophysiol 1998;9:462-469.

19. Jais P, Haissaguerre M, Shah DC. Chouairi S, Gencel L, Hocini M, Clementy J. A focal source of atrial fibrillation treated by discrete radiofrequency ablation. Circula-
fion $1997: 95: 572-576$. 
"Class IC atrial flutter": Electrocardiographic and electrophysiological findings and their importance for long-term outcome after right atrial isthmus ablation

\author{
Ashish Nabar, MD; Luz-Maria Rodriguez, MD; Carl Timmermans, MD; \\ Rob van Mechelen, * MD and Hein J.J. Wellens, MD. \\ Department of Cardiology. Academic Hospital Maastricht \\ and Sint Franciscus Gasthuis, Rotterdam. *
}




\section{ABSTRACT}

Background: Recent reports suggest dinical benefit, at least short-term, after right atrial (RA) isthmus ablation, in patients showing conversion of atrial fibrillation (AF) to atrial flutter (AFL) while taking antiarrhythmic ding (AAD) therapy. The aim of this study was in to describe the electrocardiographic (ECG) and electrophysiologic characteristics of the $A F L$, developing in patients taking dass IC AAD therapy for recurrent $A F$, the so called "class $1 C A F L$ " and 2) to report long-term success following RA isthmus ablation, in relation to their ECG pattern during AFL.

Methods: The 12-lead ECG, findings during electrophysiological study, acute results of RA isthrnus ablation, and long-term outcome as to AF recurrences were examined in 24 consecurtive AF patierts (54 512 years, 19 males) who were diagnosed as developing AFL while taking propafenone $(n=12)$ or flecainide $(n=12)$.

Results: On retrospective analysis, ECG was considered suggestive of typical AFL, when flutter waves showed a regular rhythm with sharp negative deflections in the inferior leads and positive deflections in lead $V 1$. This was found in 13 patients $(54 \%)$. The ECG was classified as atypical AFL $(n=8)$ or coarse $A F(n=3)$ in the remaining patient5. On electrophysiological study, the RA isthmus conduction time was slower in lateromedial than in mediolateral direction (104:-132 ms versus $75 \pm 34$ $m s, P=0.023$ ). During the study, a counterdockwise (C(W) AFL was documented in 7 out of 7 and 4 out of 5 patients having typical and atypical AFL respectively. Acute success of ablation was similar in patients with typical (92\%) and atypical (100\%) AFL. At long-term follow-up (13 56 ; range, $6-26$ months), continuation of AAD therapy resulted in better control of AF recurrences, in patients with typical than an atypical AFL. Coarse AF $(n=3)$ persisted despite ablating the RA isthrnus. At follow-up all 3 patients continued to have frequentrecurrences of AF.

Conclusions: This study shows that, in class IC AFL electrocardiographically both typical and atypical AFL morphologies are seen. The AFL circuit was always located in the RA and the isthmus was crucial for maintaining reentry. The best long-tem control of AF using the "hybrid" approach was obtained in patients with an AFL ECG pattern of typical AFL. Patients developing coarse AF are no candidates for this strategy. 
Chaprer 4 Long-term outcome after ablation of "Chass IC atrial fluther"

\section{Introduction}

The architecture of the right atrium (RA) provides natural obstacles or barriers promoting the development of atrial flutter (AFL)!' Indeed, the macro-reentrant circuit of AFL is located in the RA in $80-85 \%$ of the ases. Atrial fibrillation (AF) may be based on eicher a "mother" macro-reentrant circuit with "daughter" waves, random reentry or rapid focal activity. "s.t Under antiarrhythmic drug (AAD) therapy, "organization" of AF in craniocaudal direction along the crista terminalis has been observed. ${ }^{5}$ "Transformation of AF to AFL requires prolongation of the reentrant wavelength, ${ }^{6}$ resulting in a single macro-reentrant loop. AADs may promote this conversion ${ }^{7}$ by slowing RA isthmus conduction ${ }^{8}$ and by limiting transversal conduction across the crista terminalis. Although, not studied systematically, the incidence of AFL in patients taking class IC AADs for recurrent $\mathrm{AF}$ is estimated to range from $3.51020 \%$. ${ }^{10}$

A typical AFL may occur, when patients with AF develop AFL after administration of class IC AADs. ${ }^{11,12}$ However, atypical electrocardiographic (ECG) and intracardiac electrogram patterns of AFL have also been noted. ${ }^{2}$ After short-term follow-up, the "hybrid" therapy of isthmus ablation and ADs has been reported to prevent or reduce the recurrences of AF in patients in whom use of AADs resulted in "conversion" of AF to AFL 7.11 .12 However the usefulness of this approach will depend upon the results obtained during long-term follow-up.

We defined "class IC atrial flutter" as a new AFL developing in patients taking proparenone or flecainide for recurrent episodes of AF. 11 The aim of the present study was 1) to describe the ECG characteristics and the electrophysiological findings during radiofrequency (RF) ablation of class IC $A F L$, and 2) to report long-term succes following $R A$ isthmus ablation, in relation to their ECG pattern during AFL.

\section{Methods}

Study population: Twenty-four consecutive patients, who underwent electrophysiological study and RF ablation, between March 1997 and January 1999, for the so called class IC AFL were included in the study. Before class IC AAD therapy, every patient was symptomatic with recurrent and disabling episodes of AF, since $8 \pm 9$ years ( 3 months -30 years). AF was paroxysmial in 9 and persistent in 15 patients. Prolonged periods of sinus rhythm could not be maintained, in spite of $3 \pm 1.6$ (range, 1-6) AADs per patient. In the past, 3 patients had received an atrial defibrillator (Metrix, Atrioverter, [nControl Inc, Redmond, WA). A dual chamber pacemaker was implanted in 1 patient for a sick 
sinus syndrome. In none of the patients, AFL was documented before the use of dass $1 C$ therapy. The clinical chanacteristics of the 24 patients are described in Table 1. An equal number of patients were taking propafenone 450 -900 mg/day) or fecanide (100-400 mg/day) when "conversion" to class IC AFL was observed.

ECG: The 12-lead ECG recorded during the clinical AFL episode was classiffed with regard to the morphology of the flutter waves. Typical AFL was defned as the presence of regular futter waves showing negative (or predominanty negative with a teminal positive deflection) deflections in the inferior leads and an entirely or predominantly positive flutter wave in lead V1 (Figure 1 , A) ${ }^{2}$ A FL, with uniform, regular futter waves but another morphology, either in the inferior leads or lead $V$, was classified as arypical (Figure 1, B). The ECG classification was done in retrospect by one of the investigators ( $H W$ ), unaware of the findings during the electrophysiologic study

Electrophysiological study and RF ablation procedure: The electrophysiological study and RF ablation was performed after informed consent and the patient in the post absorptive state. Details of the procedure are described clsewhere."13 The RA activation pattern was recorded from a duodecapolar Halo catheter (Cordis- Webster, Baldwin Park, CA, USA) positioned around the tricuspid annulus, and preferably a multipolar catheter (Condis-Webster, Baldwin Park, CA, USA) was placed in the coronary sinus (CS) so that its proximal bipole was at the ostium. At the beginning of the study and when possible, bidirectional isthmus conduction (BLC) ${ }^{14}$ was evaluated at a pacing cycle length of $600 \mathrm{~ms}$. The AFL induction protocol consisted of up to 3 atrial extrastimuli delivered after a basic 10-beat drive, with 3 different cycle lengths. Incremental atrial pacing was performed, when necessary. Isthmus activation time (time interval between the Halo bipote positioned at the low latenal RA and the proximal CS bipole) was axpressed as a percentage of futter cycle length. We refrained from performing entrainment studies, because in the initial procedures attempts to entrain class IC AFL resulted in induction of sustained AF. In case of a sustained AF induced inadvertently, sinus thythm was restored by cardioversion. Ablation of the RA wsthnus was performed by an anatomical approach.

Acute procedural result: Atier RA isthmus ablation, success was judged by denonstrating noninducibility of AFL and BIC block. The procedure was considered a partial success if AFL was rendered noninducible in the absence of complete BIC block. The procedure had faled if AFL remained inducible. Procedural success was confinned under isoproterenol infusion $(1$ to $3 \mu \mathrm{g} / \mathrm{min})$. ${ }^{5}$

Follow-up protocol: After the procedure, patients were advised to take propatenone or flecainide. Follow-up was conducted at 8 weeks and then at 
Table H. Clinical characteristics of the 24 Patients Studied.

\begin{tabular}{|c|c|}
\hline Age (years) & $34 \pm 12$ \\
\hline Male/fenale, n/n & $19 / 5$ \\
\hline \multicolumn{2}{|l|}{ Structural hear disemse $n$} \\
\hline None & 17 \\
\hline Mild mitral regurgitation & 4 \\
\hline Mild left ventricular dyst unction & 1 \\
\hline Snall atrial septal defect & 1 \\
\hline Conrected Ebstein's enonaly & 1 \\
\hline Leftatrial s $\mathrm{ze}(\mathrm{cm})$ & $46 \pm 04$ \\
\hline Duration of AF (years) & $8 \pm 9(3$ mo 30 years \\
\hline Number of previously falled AABS $n$ & $3 \pm 16(1-6)$ \\
\hline
\end{tabular}

3-month intervalis. Holter recordings were requested predischarge, at 8 and 12 wecks after the procedure, and when symptoms suggested an arrlyythmia recurrence.

Patients having a documented recurrence of AFL were advised to undergo re-ablation. After isthmus ablation, patients having no AF recurrences, asymp tomatic recurrences (AF detected only by Holter, Atrioverter or pacemaker device), or symptomatic but short-lasting AF recurrences were considered to be well-controlled. These patients were taking either propafenone or flecainide, and occasionally a class III AAD or calcium antagonist was added for further control of AF recurrences. Patients who continued to have frequent or symptomatic AF recurrences, despite alterations in the $\mathrm{AAD}$ regimen, were considered as inadequately controlled.

Statistical analysis: Results were expressed as mean \pm SD and range and proportions as percentages. Mean values were compared by 1-way ANOVA test and $\chi^{2}$ test was used for testing homogeneity in contingency tables. Results were considered to be significant at $5 \%$ critical level $(\mathrm{P}<0.05)$.

\section{Results}

Twelve lead ECG during a clinical recording of class IC AFL: Thirteen patients (54\%) were classified as typical AFL. In 8 other pationts, the fluter wave deflection was different in the inferior leads and lead V1. They were classified as atypical AFL. The mean AFL cycle length was $268 \pm 34 \mathrm{~ms}$ (range, 220 360 ms). Atrioventricular (AV) conduction was variable in 9 patients, fixed $2: 1$ in 10 , and $1: 1$ in 1 patient (flutter rate, $360 \mathrm{~ms}$ ). In the remaining 3 patients there were small differences in interval and configuration of the atrial deflections, and they were classified as fibrillo-flutter or coarse AF (Figure 1, C). 


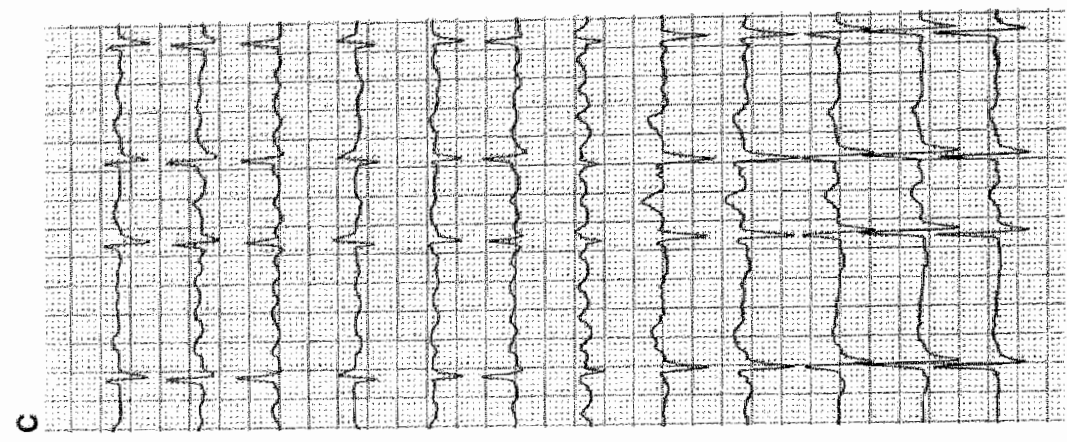

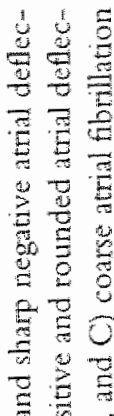

78
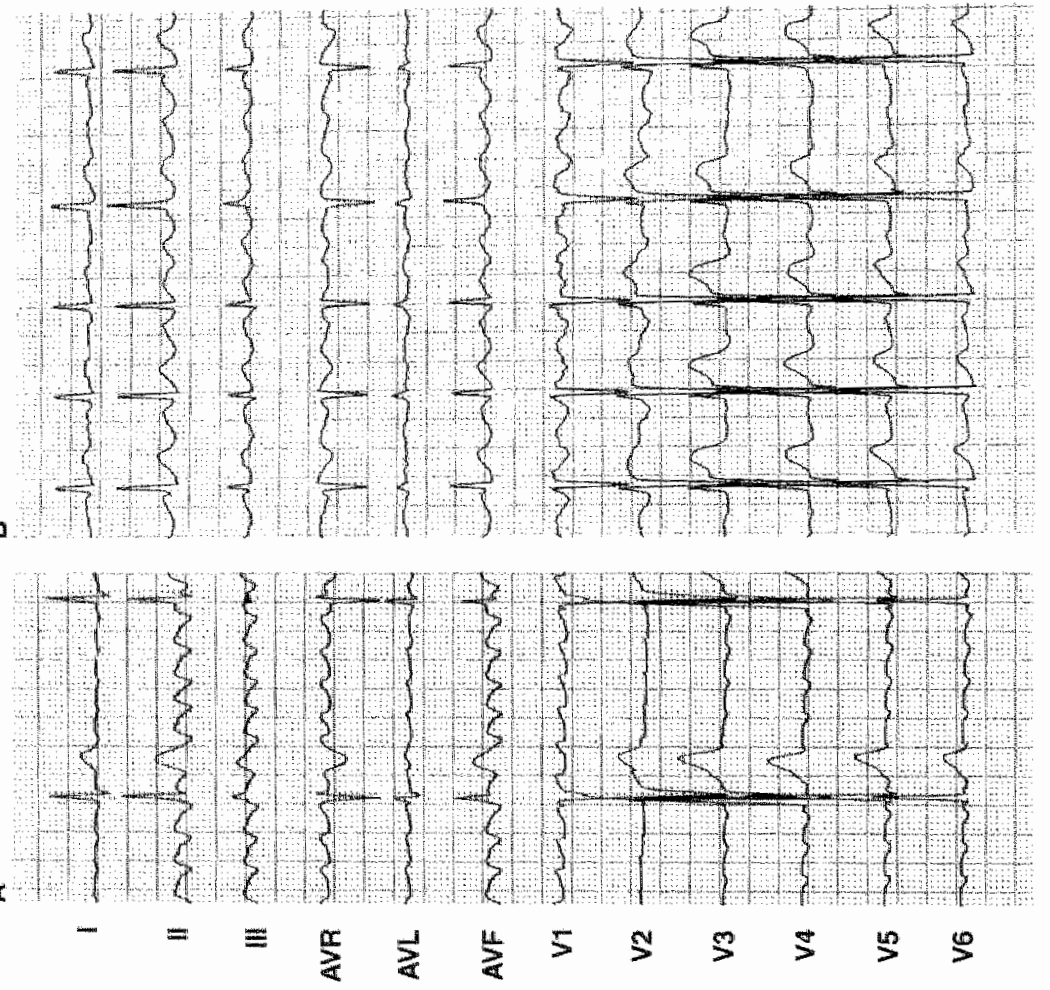

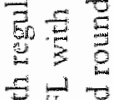

要焉

를

$\leq \sum_{0}^{5}$

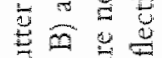

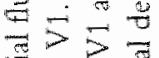

马

I $\Xi \exists$

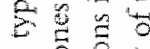

< 5.5

$3 \stackrel{3}{3}$

9.53

(골

(4)

马

$\frac{2}{3}=5$

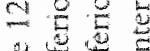

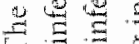

$-5$

$\pm \Xi \Xi$

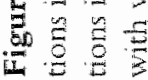


Table 2 Findings during Electrophysiologiral study

\begin{tabular}{|c|c|c|c|}
\hline 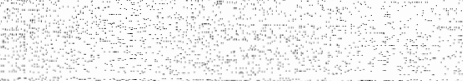 & $\begin{array}{l}\text { Typal ALt } \\
(\mathrm{n}=13)\end{array}$ & $\begin{array}{l}\text { Atupicalaft } \\
(\mathrm{n}=8)\end{array}$ & $\begin{array}{c}c 0 \text { ma AB } \\
(n=3)\end{array}$ \\
\hline \multicolumn{4}{|l|}{ Arl inducibility $n(\%)$} \\
\hline Incessanty present & 401 & 224 & $3(000)$ \\
\hline Induced & $3(23)$ & 398 & 0 \\
\hline Noninducible & $6(46)$ & $3(38)$ & 0 \\
\hline Right atrial actwotion during $A F(n / \phi)$ & $(\mathrm{n}=7)$ & $(n-5)$ & $(n-3)$ \\
\hline Countrerclockmise & $7(100)$ & $4(80)$ & $3(100)$ \\
\hline Clockwnse & 0 & 120 & 0 \\
\hline AFL cycle length stability $\cap(\%)$ & $(n-7)$ & $(n=5)$ & $(n=3)$ \\
\hline Yes & $6(86)$ & $4(80)$ & 133 \\
\hline No & 114 & (20) & $2(6)$ \\
\hline Left atral response during $A F, n(\rho)$ & $(n=6)$ & $n=5)$ & $(n=1)$ \\
\hline $11+2$ & $6 / 100$ & $5(100)$ & 0 \\
\hline $\mathrm{AF}$ & 0 & 0. & $1100)$ \\
\hline Episodes of sustained AF, n (\%) & $6(39)$ & 398 & 3100) \\
\hline AF, Atrial fibrillation, ARL Atrial fluiter. & & & \\
\hline
\end{tabular}

Findings during the electrophysiological study: Prior to RF ablation, BIC could be assessed in 17 patients. The mean lateromedial isthmus conduction time was longer than the mediolateral isthmus conduction time ${ }^{16}(104 \pm 32 \mathrm{~ms}$ versus $75 \pm 34 \mathrm{~ms}, \mathrm{P}=0.023$ ).

Table 2 summarizes the findings during electrophysiological study. From the beginning of the procedure, AFL was continuously present in 6 patients. In 6 more patients, a sustained AFL could be induced by; programmed atrial premature beats $(n=3)$, atrial premature beats related to catheter manipulation $(n=1)$, and spontaneous transition from on going AF $(n=2)$. AFL could not be induced in $9(43 \%)$ patients. There was no difference as regards inducibility, in patients with typical or atypical AFL. AF was present during most of the procedure, in the 3 patients later classified as coarse AF.

Therefore the intracardiac atrial activation pattern could be studied during AFL in 12 patients. The RA activation pattern was constant and repetitive in every patient (Figure 2). The direction of activation was counterclockwise $(\mathrm{CCW})$ in every patient $(\mathrm{n}=11)$, except 1 . The mean isthmus activation time constituted $35 \% \pm 14 \%$ of the flutter cycle length. Most of the patients with typical $(6$ of 7 ) and atypical. (4 of 5 ) AFL showed a stable cycle length. As 


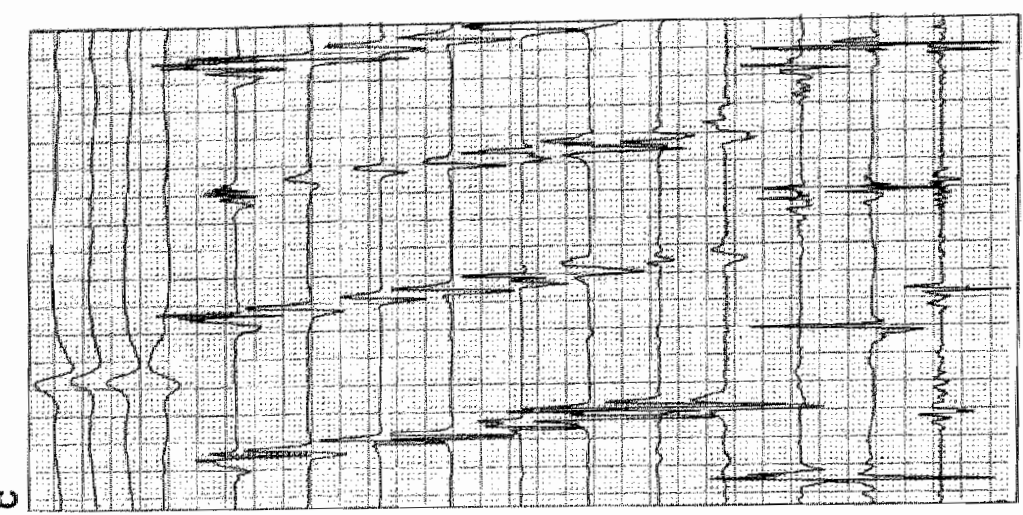

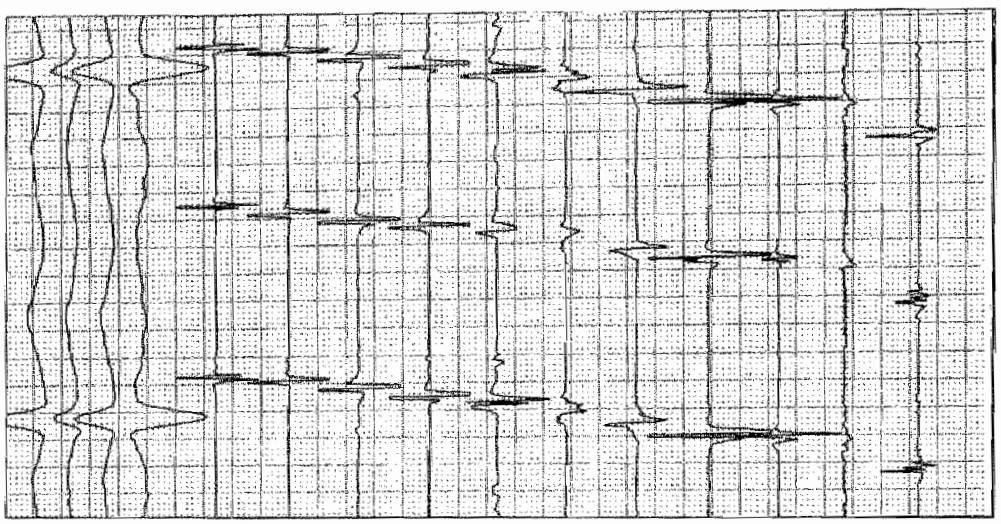

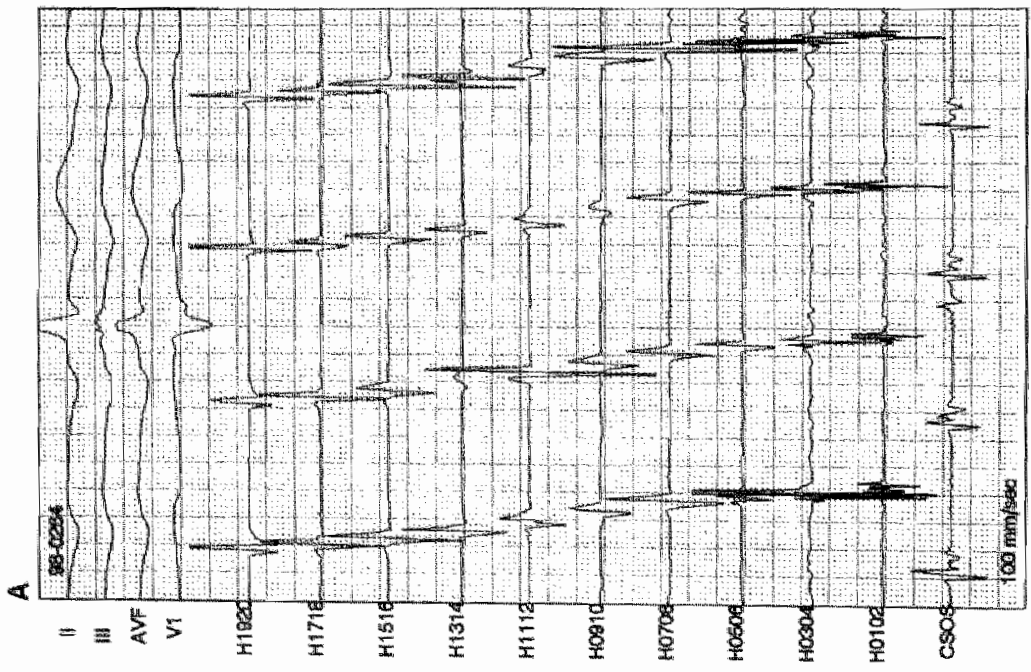

$6 \widehat{0}$

을을

웡 8

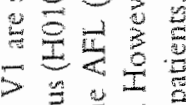

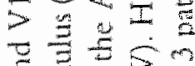

范它可

$3 \div 50$

$<$ 政

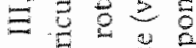

$=5 \mathrm{~s}$

를 可U $0 \%$ 영 出 Q

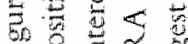

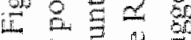

$\exists$ 要 ए匹

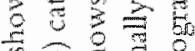
을 음 远厓

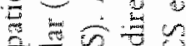
$-8=0$

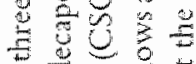
证

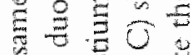

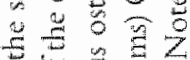

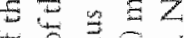
을

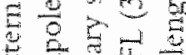
흘 졍 द

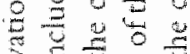

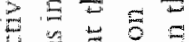
类 焉焉造 $=8 \mathrm{~g}$ 范范 ․ㅡㄹ i 30 药

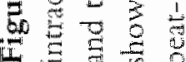




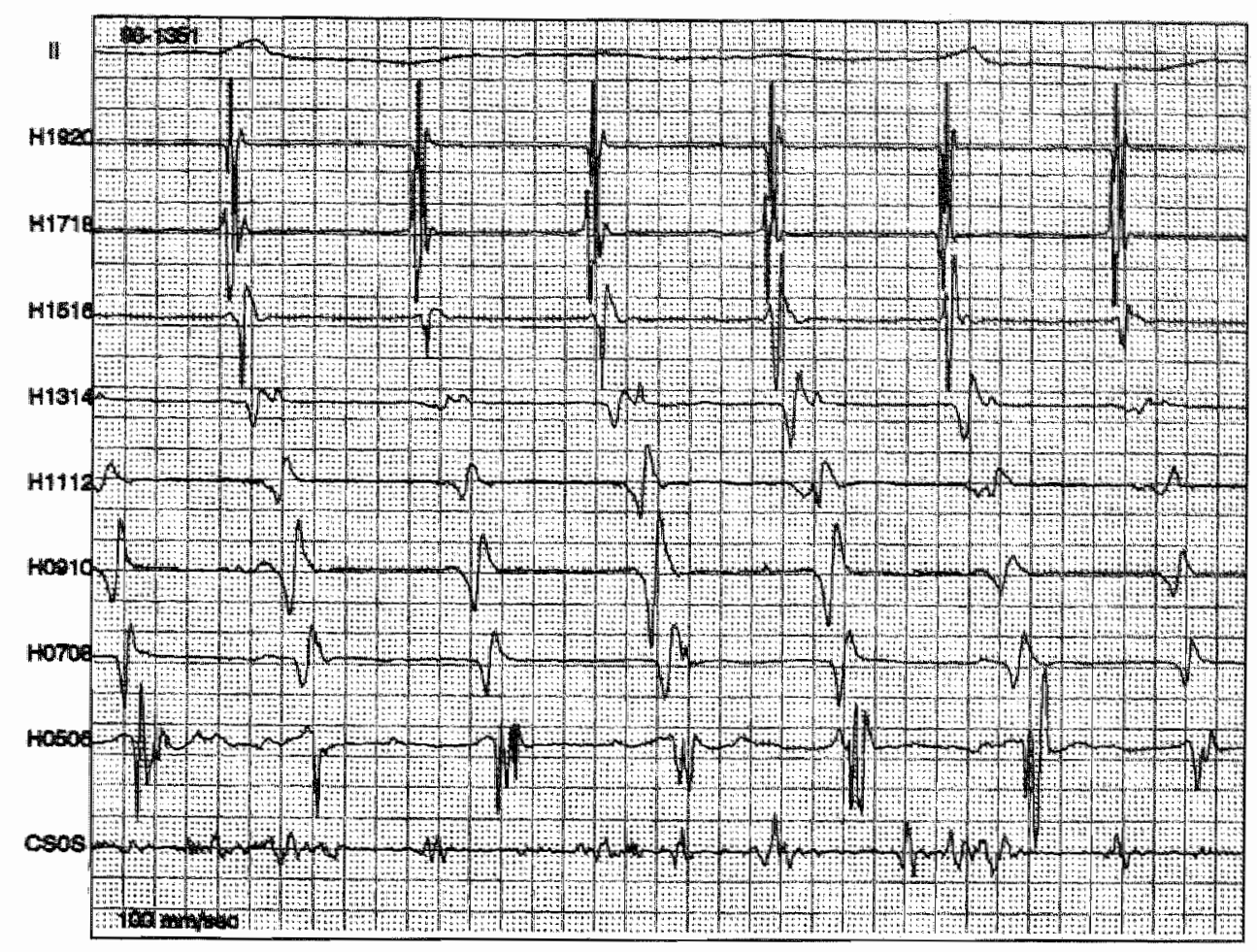

Figure 3. An example of class IC AFL. Note that the RA endocardial activation shows CCW rom tation (H0506 to H1920). Electrograms from the coronary sinus (CS) suggest left atrial fibrillation.

expected, patients with coarse AF ( 2 of 3 ) had a beat-to-beat variation in the atrial cycle length. The atrial cycle length was stable in the remaining 1 patient with coarse AF.

Simultaneous recordings from the CS were avalable in 12 of the 15 patients mentioned above. The left atrial (LA) response was consistently $1: 1$ in 11 patients. In the remaining patient, CS electrograms were indicative of LA fibrillation (Figure 3). Multiple recordings from the CS were available in only 5 of the former 11 patients. In 4 of these patients with CCW-AFL, the activation sequence of the CS was; proximal to distal $(n=1)$, distal to proximal $(n=2)$ and simultaneous $(n=1)$. In 1 patient with clockwise AFL, the CS activation was proximal to distal.

Atrial fibrillation during ablation of class IC AFL: Sustained AF was precipitated inadvertently in $8(38 \%)$ patients, including 5 patients with rypical and 3 with atypical AFL. During the procedure, at least on 1 occasion, every patient with coarse $\mathrm{AF}(\mathrm{n}=3)$ showed disorganization of $\mathrm{RA}$ activation (absence of repetitive pattem of activation along the Halo catheter). Sinus rhythm was 
restored by external $(n=5)$ or internal $(n=2)$ electrical cardioversion, intravenous flecainide $(n=1)$ or overpacing $(n=1)$. In the remaining 2 patients, a spontaneous reversion to AFL was observed.

Acute procedural result: $A$ linear ablation of the RA isthmus was performed durng CS pacing $(n=13)$, AFL $(n=6)$ or both rhythms $(n=4)$. In 1 patient, with recurrent spontaneous induction of $\mathrm{AF}$, the ablation was performed during sinus rhythm (without CS pacing). The results of ablation are included in Table 3.

The ablation was judged as successful, after noninducibility of AFL and BIC block, in 18 out of 21 patients. Success was considered as partial in 2 patients, because of noninducibility alone in 1 patient (typical AFL) and noninducibility and unidiectional isthmus conduction block in another patient (atypical AFL). In the remaining 1 patient who had a typical AFL, ablation was considered unsuccessful. In case of the 3 patients with coarse AF, after ablation of both the RA isthmi, coarse AF was persistently present in 2 patients. It is of some interest that, coarse AF was not inducible after obtaining BIC block in the remaining 1 patient. When the 3 groups were compared, in contrast to patients with coarse AF, the acute effect of isthmus ablation was considered to be successful in a high number of patients with typical $(92 \%)$ or atypical (100\%) AFL.

Long-term follow-up results: A mean follow-up of $13 \pm 6$ months (range, $6-26$ ) was available (Table 3). After an initially successful ablation, 4 parients ( 3 with typical and 1 with atypical AFL) had a recurrence of AFL, $9 \pm 4$ months (range, 3 - 15) later. In these 4 patients, acute success had been judged by: noninducibility alone $(n=1)$, noninducibility and unidirectional isthmus conduction block $(n=1)$, and noninducibility and BIC block $(n=2)$. All 4 patients underwent successful re-ablation, with confirmation of BIC block under isoproterenol infusion. At the last follow-up, all 4 patients were free of AFL recurrences.

Of the 13 patients who underwent ablation for typical AFL, recurrences of AF were prevented in $11(85 \%)$ paticnts. Class IC AADs were stopped in 2 patients, whereas 9 patients continued taking class IC medication alone 7 patients) or in combination with sotalol ( 2 patients). Recurrent episodes of AF were found in 2 patients. Out of the latter 2 patients, 1 patient with operated Ebstem's anomaly had an unsuccessful ablation of AFL. The other patient had AF recurrences, after successful $R A$ isthmus re-ablation for an AFL recurrence, in spite of the addition of amiodarone to flecainide. After ablation of atypical AFL ( $\mathrm{n}$ $=8$ patients), 4 patients $(50 \%$ ) showed a reduction in AF recurrences while taking chass $1 \mathrm{C}$ medication alone. Frequency of $\mathrm{AF}$ recurrences did not change in other 4 patients. Clearly, more patients with typical as compared to atypical AFL, had an improvement in control of their AF recurrences after ablation of the isthmus. Not surprisingly, all 3 patients who underwent isthmus ablation despite of coarse AF contimued to have frequent recurrences of $\mathrm{AF}$. 


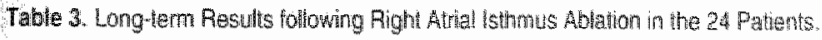

\begin{tabular}{|c|c|c|c|c|c|c|c|c|}
\hline Ho: & $\begin{array}{l}\text { Cass } 1 \mathrm{G} \\
\mathrm{AF}\end{array}$ & $\begin{array}{l}\text { Class IC } \\
\text { ADDused } \\
\text { (mo/day) }\end{array}$ & $\begin{array}{l}\text { Aculte: } \\
\text { Resulit }\end{array}$ & FU & $\begin{array}{l}\text { Rect } \\
\text { AFL }\end{array}$ & $\begin{array}{l}\text { mencos } \\
\text { AF }\end{array}$ & $\begin{array}{l}\text { AADS a los } \\
\text { tolow-11p } \\
\text { mpiday }\end{array}$ & $\begin{array}{l}\text { Comblol ol } A^{\circ} \\
\text { redurenoss }\end{array}$ \\
\hline 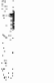 & Typical & $\begin{array}{l}\text { Propatenone } \\
\text { (onol }\end{array}$ & $\begin{array}{l}\text { Success } \\
N+B \mid C B\end{array}$ & 8 & 能o & $\begin{array}{l}\text { Few shortlasting } \\
\text { episoues }\end{array}$ & Propalenon $(750)$ & Well-controlled \\
\hline 2 & Typica: & $\begin{array}{l}\text { Pllopafenone } \\
4501\end{array}$ & $\begin{array}{l}\text { SUC6ess } \\
\text { NHBCBD }\end{array}$ & 21 & No & None & $\begin{array}{l}\text { Aithold (25). Propa- } \\
\text { fenone stopper. }\end{array}$ & Wellontroliged \\
\hline 3 & Typical & $\begin{array}{l}\text { Flecainitá } \\
\text { (200) }\end{array}$ & $\begin{array}{l}\text { Partial } \\
\text { N }\end{array}$ & 9 & Yes & $\begin{array}{l}\text { Recurrent episodes, } \\
\text { external cardioversion } X 1\end{array}$ & $\begin{array}{l}\text { Fochinde (100) : } \\
\text { Amiadarone (200) }\end{array}$ & Not controllew \\
\hline 4 & Typical & $\begin{array}{l}\text { Flecainide } \\
\text { (200) }\end{array}$ & $\begin{array}{l}\text { Success } \\
\text { NitBCB }\end{array}$ & 16 & No & $\begin{array}{l}\text { Few, short-basing } \\
\text { episoddes. Detocted by } \\
\text { Atrioverter }\end{array}$ & $\begin{array}{l}\text { Flecainide (200) + } \\
\text { Metuprolol }(25)\end{array}$ & Well-contralled \\
\hline 5 & Typical & $\begin{array}{l}\text { Propalenonte } \\
(450)\end{array}$ & $\begin{array}{l}\text { Success } \\
M 1+B I C B\end{array}$ & 10 & No & None & Flecainde $(200)$ & Well-controled \\
\hline 6 & Typica! & $\begin{array}{l}\text { Flewainide } \\
(100)\end{array}$ & Failed & 18 & No & Recurrent episodes & Flecainice (100) & Wot sontrolled \\
\hline 7 & Typical & $\begin{array}{l}\text { Propalenone } \\
(450)\end{array}$ & $\begin{array}{l}\text { Sucoess } \\
\mathrm{NH}+\mathrm{BlCB}\end{array}$ & 15 & Yes & $\begin{array}{l}1 \text { episode, } 2 \text { hours, } \\
\text { asymptomatic, Detected by } \\
\text { Holter }\end{array}$ & $\begin{array}{l}\text { None, Propatenone } \\
\text { stopped }\end{array}$ & Wal-controlled \\
\hline
\end{tabular}

2. Typical

Propatenone Success 12 No 2 symptomatic eplsodes,

$1900) \quad \mathrm{Nl} H \mathrm{BICB}$ lasting 2 hours and 3 days

Propalenone $(450)$ i Well-controlled Sotalol (80)

$9 \quad$ Typical

Flecainide Success 14 No None

(100) $\quad N+B+C B$

Flecairide (100) +

Welloromtrollied

10 Typical

Propalenone Success 110 Yes Fev, shontlasting (900) NitBICB episodes

Dillitian $\mathrm{SR}(120)$

Propallenone $(600)+$ Well-controlled Solalol (80)

11 Typtical

Propatenone

Success 9 No

Few episodes on disconti-

(450) $\mathrm{NI}+\mathrm{BICE}$ nuing $A A D$ s, restratled.

Propatenone $(450)+$

Well.controlled

12 Typical

Fecalnide

Succese 6 No 3 surriptomatic eptrodes

(150)

Nit. 8108

Atenolol (25)

Flecainide 150 .

Meloptotol (25)

13 Typical

Flecainice

(200)

Sucoess 13 No Few shot asting opisodes $\mathrm{NH}+\mathrm{BHCO}$

14 Aypical

Flocainide

(300)

Success 25 No Few shontrysting \& 1

$\mathrm{NH} . \mathrm{BCO}$

sustained episode

15 Atypical

Propatenone

Partial 26 Yes flecurent, multiple AADS

Whatheonteled

MI:UICB

used \& Africureter shocks

16 Atypical

Flecainide

Suctess 2

(200)

$\mathrm{N}+\mathrm{BICB}$

No

Amiodarone added, hyper

-thyroidism, extental

cardlowersion $X$ a

recurrent $A F$

7 Alypical

Propaterone

Success 1 ho Few, shorllasting

(600)

$\mathrm{NI}+\mathrm{BICB}$

recurrences

18 Amical

Proparenone

Success
$M+B H C B$

$10 \mathrm{NO}$

Mecurrent, mulipiple

(450)

Atroventer shocks

Fiecaninde (100)

Metoprolol (25)

Ampodarone

Flecainde $(100)$

Walconiroled

Wel-controlited

Not conirolled

Fiecranide $[200]+$

Metoprolol (50)

Not conirolled

Propatenone $(450)$ Wellcontrolled Metoprolol (50)

Propatenone (450) + Not contulled

Metoprolol (50) 
Tallo Continued

\begin{tabular}{|c|c|c|c|c|c|c|c|}
\hline $4 \mathrm{Clags} \|$ & 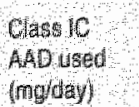 & $\begin{array}{l}\text { Acule: } \\
\text { Resul }\end{array}$ & EU & AfE & mence & 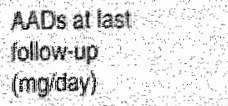 & $\begin{array}{l}\text { Controlof } A F \\
\text { monrronces }\end{array}$ \\
\hline Alyoud & flectinde & $\begin{array}{l}\text { Suceess } \\
\text { Mhables }\end{array}$ & 6 & No & $\begin{array}{l}\text { Fen, shor wasting } \\
\text { recurreness }\end{array}$ & $\begin{array}{l}\text { Heramole } 200 \mathrm{H} \\
\text { Melopolol }(100)\end{array}$ & elloontroled \\
\hline Alytol & 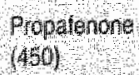 & $\begin{array}{l}\text { suocoss } \\
\text { Nh bICE }\end{array}$ & 8 & Ho: & Recurrent epessodes. & Aniodasone $(200)$ & comtrolled \\
\hline Aluplot & flocentse & 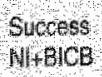 & 11 & No & $\begin{array}{l}\text { Had AF recurences on } \\
\text { roducing Flecarde (100) }\end{array}$ & $\begin{array}{l}\text { Flacande }(409) \\
\text { plodold }(5)\end{array}$ & Aollcontroles \\
\hline torse AP & (7000 & Patled & 9 & No: & $\begin{array}{l}\text { Recurret opisodes No } \\
\text { response to Disopyamide }\end{array}$ & $\begin{array}{l}\text { Flecalode }(400) \\
\text { Metoptolol }(50)\end{array}$ & ontroled \\
\hline DOArseAf & F(rodida & NAPUCB & 10 & No: & 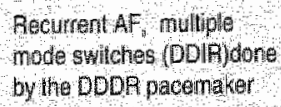 & 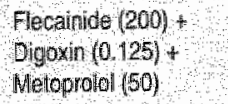 & Nol controlled \\
\hline Coares & $\begin{array}{l}\text { Popplonone } \\
\text { (6) }\end{array}$ & Falled & 8 & No & Chront permanent AF & Amitdarote 200$)$, & Hed \\
\hline
\end{tabular}

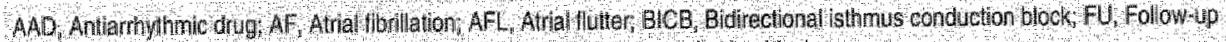

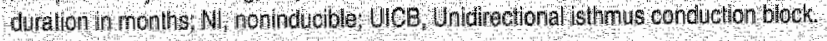

\section{Discussion}

"Class IC AFL": In the present study, the electrocardiographic morphology of class IC AFL was the typical AFL morphology in $\approx 50 \%$ of the patients. The remaining half, based on the morphological characteristics of the atrial deflections in the ECG were classified as showing atypical AFL or coarse AF. The mean fluter rate $268 \pm 34 \mathrm{~ms}$ ) was slow because of the class IC therapy. During the electrophysological study, no differences between typical and atypical AFL were noted in regard to the pattern of activation during AFL. The flutter circuit was always localized to the RA, having a CCW direction in the majority of patients. The preference for $\mathrm{CCW}$-reentry may be based on a slower isthmus conduction in lateromedial, in comparison to the mediolateral direction (104 \pm 32 ms versus $75 \pm 34 \mathrm{~ms}, \mathrm{P}=0.023$ ). The mean isthmus activation time was $35 \%$ $\pm 14.3 \%$ of the flutter cycle length. This was longer, as compared to the isthmus activation time $(25 \%-27 \%)$ reported in another study, ${ }^{16}$ and might support the presence of a macro-reentrant circuit. In most of the patients (11 out of 12), where this was recorded, the LA responded to the RA-reentrant circuit in a $1: 1$ fashion. This finding is compatible with the argument, that LA is a simple bystander and not essential to the AFL circuit. ${ }^{2}$ The limited recordings from CS 
using multiple electrodes do not allow an impression of global LA activation. The importance of the LA activation sequence, in determining the electrocardiographic polarity of flutter wave, has been demonstrated in a canine model of AFL. ${ }^{17}$ In the present study, it remains speculative whether differences in LA activation, are responsible for the observed differences in electrocardiographic morphology of class IC AFL. Although a recent study pointed to the lack of correlation between direction of rotation of AFL and the polarity in the inferior leads, ${ }^{18}$ our observations suggest that the predominantly negative flutter waves in the inferior leads and positive flutter deflections in lead V1, indicate class IC AFL patients who do well after RA isthmus ablation.

RF ablation of class IC AFL: Every patient underwent a linear ablation of the RA isthmus. Thereafter noninducibility of AFL could be achieved in the majority of patients with either a typical $(92 \%)$ or atypical (100\%) AFL. A majority of patients studied by Huang et al, ${ }^{7}$ developed AFL while receiving amiodarone for recurrent AF. That study reported a better procedural outcome following ablation of typical AFL. In terms of reccurences of AF, our long-term follow-up suggests better late results in patients with typical AFL.

Development of Coarse AF after class IC AAD therapy: Three patients with coarse AF underwent isthmus ablation. Every patient showed a stable RA activation pattem, but a beat-to-beat variation in the cycle length was present in 2 patients. Noninducibility could not be achieved after ablating both the RA isthmi in 2 patients. Furthermore, at long-term, AF recurrences occurred in all 3 patients. These findings confirm that, conduction through the isthmus is not critical to the maintenance of coarse AF. Based on the results of this study, these patients should not be considered candidates for the "hybrid" approach.

\section{Study limitations}

Nearly $50 \%$ of our patients with class IC AFL had an atypical morphology. In the absence of detailed mapping from the atrial septum and left atrium, the reasons for differences in electrocardiographic morphology of class IC AFL could not be understood. In 9 (43\%) patients, AFL could not be induced. In these patients, with noninducible but clinically documented class IC AFL, complete BIC block had to be accepted as an procedural endpoint. In the absence of entrainment studies, determining the location of class IC AFL circuit and its isthmus dependence, based on a circular pattern of $\mathrm{RA}$ activation, is a limitation. However, we decided not to attempt entrainment, because of the precipitation of sustained AF early in the series. The frequency of AF recurrences during follow-up is at best an estimate. Asymptomatic recurrences could go undetected 
even with the use of Holter montoring or event recorders. However, the frequency of symptomatic AF recurrences requiring treatment is directly relevant to the patient.

\section{Clinical Implications}

This study shows that, after class IC AAD therapy for AF, both typical and atypical AFL-ECG morphologies are seen. The AFL circuit was always located in the RA and the RA isthmus was involved in the reentry mechanism. Long-term success, defined as improvement in control of AF recurrences, with the "hybrid" approach, was higher in patients who underwent RA isthmus ablation for typical AFL. Less patients, when treated by this approach, benefited during long-term, when the RA isthmus ablation was performed for atypical AFL. Patients with coarse AF are no candidates for this strategy.

\section{References}

1. Cabrera JA, Sanchez-Quintana D, Ho SY, Medina A, Anderson RH. The architecture of the atrial musculature between the orifice of the inferior vena caval vein and the tricuspid valve: the anatonny of the isthmus. $J$ Cardionase Electrophysiol 1998;9:1186-1195.

2. Cosio FG, Arribas F, López-Gil M, Goicolea A. Endocardial catherer mapping of atrial arrhythmias. In Shenasa M, Borggrefe M, Breithardt $G$, eds: Cardioc Mapping. Futura Publishing Co, Inc., Mount Kisco, NY, 1993:443-459.

3. Konings KTS, Kirchoff CHJH, Smeets JLRM, Wellens HJ, Penn OC, Allessie MA. High-density mapping of electrically induced atrial fibrillation in humans. Circulation 1994:89:1665-1680.

4. Jais P. Haissaguerre M, Shah DC, Chourairi S, Gencel L, Hocini M, Clémenty J. A focal source of atrial fibrillation treated by discrete radiofrequency ablation. Civculariou 1997:95:572-576.

5. Roithinger FX, SippensGroenewegen A, Karch MR, Steiner PR, Ellis WS, Lesh MD. Organized activation during atrial fibrillation in man: endocardial and electrocardiographic manifestations. I Cardionasc Electrophysiol 1998;9:451-461.

6. Matsuo K. Kumagai K. Annoura M, Ideishi M, Arakawa K. Mechanism of antiarrhythmic effects of class Ic drugs in paroxysmal atrial fibrillation in man. Cardibosy 1998;89:119-123.

7. Huang DT, Monahan KM, Zinetbaum P, Papageorgiou P. Epstein LM, Josephson ME. Hybrid pharmacologic and ablative therapy: a novel and effective approach for the management of atrial fibrillation. J Cordionase Electrophysiol 1998;9:462-469. 
8. Yamashita $T$, lnoue $H$, Nozaki A, Tsong-teh $K$, Usui $M$, Sugimoto T. Role of anisotropy in determining the selective action of antiarhythmics in atrial futter in the dog. Cardiouas Res 1992;26:244-249.

9. Schumacher B, Schmidt H, Fischenbeck C. Lewalter T, Wolpert C, Jung W. Luderitz B. Pulse propagation through the crista teminalis in patients with atrial fibrillation and atrial futter. I Am Coll Cardial 1998;32:221 A. Abstract.

10. Falk RH. Proarhythmic responses to atrial antiarthythmic therapy. In: Falk RH, Podrid PJ, eds. Atrial fibrilation: mechanisms and mandgentent. NY: Raven Press Ltd., 1992:283-305.

11. Nabar A, Rodriguez LM, Timmermans C, Smeets JLRM, Wellens HJJ. Radiom frequency ablation of "class IC atrial thutter" in patients with resistant atrial fibrilla cion. Am J Cardiol 1999;83:785-787.

12. Schumacher B, Jung W, Lewalter T, Vahlhaus C, Wolpert C, Lideritz B. Radiofrequency ablation of atrial futter due to administration of class IC antiarthythmic drugs for atrial fibrillation. Am J Cardiol 1999;83:710-713.

13. Poty H, Saoudi N, Nair M, Anselme F, Letac B. Radiofrequency catheter ablation of atrial Autter: further insights into the various types of isthmus block: application to ablation during sinus thythm. Circulation 1996;94:3204-3213.

14. Barold SS, Shah D, Jais P, Takahashi A, Haissaguerre M, Clémenty J. Nomenclature and characterization of transisthmus conduction after ablation of typical atrial flutter. Pacing Clin Electrophysiol 1997;20:1751-1753.

15. Nabar A, Rodriguez LM, Timmermans C, Smeets JLRM, Wellens HJJ. Isoproterenol to evaluate resumption of conduction following right atrial isthmus ablation in type I atrial tutter. Cirulation 1999;99:3286-3291.

16. Saoudi N, Nair M, Abdelaziz A, Pory H, Daou A, Anselme F, Leac B. Electrocardiographic patterns and results of radiofrequency ablation of clockwise type I atrial Hutter. J Cardiovasc Electrophysiol 1996;7:931-942.

17. Okumura $K$, Plamb VJ, Pagé PL, Waldo AL. Atrial activation sequence during atral futter in the canme pericarditis model and its effects on the polarity of the flutter wave in the electrocardiogram. J Am Coll Cardial 1991:17:509-518.

18. Lai LP, Lin $J L$, Lin $\mathbb{L}$, Chen WJ, Ho YL, Tseng YZ, Chen CH, Lee YT, Lie WP, Huang SKS. New electrocardiogtaphic criteria for the differentiation between counterclockwise and clockwise atrial flutter: correlacion with electrophysiological study and radiofrequency catheter ablation. Heart 1998;80:80-85. 



\section{Should we prefer a long tip electrode to} perform radiofrequency ablation of type I atrial flutter?

Results of a prospective randomized study comparing an 8-mm split-tip versus a $4-\mathrm{mm}$ tip ablation catheter

Luz-Maria Rodriguez, MD; Ashish Nabar, MD;

Carl Timmermans, MD and Hein J.J. Wellens, MD.

Department of Cardiology, Academic Hospital Maastricht. 


\section{ABSTRACT}

Aim: Clinical experience using a long tip electrode for radiofrequency (RF) catheter ablation of type I atrial flutter (AFL) is largely obserwational. We therefore compared a new RF catheter design with an 8-mm split-tip electrode hawing integrated thermocouples [Cerablate ${ }^{\circledR}$ plus. Futter, Dr Osypka GmbH, Grenzach-Wyhlen, Germanyl, (group I) with a 4-mm tip electrode (group ll) in a prospective randomized manner.

Methods: Thirty consecutive patients were randomized to group I or $\|$. For ablation of the RA isthmus 90 second RF pulses were used at sequential sites with a preset temperature of $55^{\circ} \mathrm{C}$. Procedural success was defined as noninducibility of AFL and bidirectional isthmus conduction (BIC) block under isoproterenol infusion.

Results: All patients in group i and all but 1 patient in group II underwent successful ablation. A significantly lesser number of RF pulses and a shorter mean fluoroscopy time was found using an 8-mm split-tip electrode [RF pulses $12 \pm 3.5$ in group I versus $27 \pm 9$ in group il $(P<0.0001)$, fluoroscopy time $23 \pm 13$ in group I versus $45 \pm$ 28 min in group $\|(P=0.01)]$. With comparable mean follow-up times $[4.3 \pm 2.8$ in group I versus $4.8 \pm 2$ months in group :1], only 1 patient in group ll had an AFL recurrence.

Conclusions: Ablation of type I AFL can be performed using an 8-mm splut-tip RF catheter. Requirement of less RF pulses and fhoroscopy time suggest superionty of an 8-mm split-tip electrode over a $4 . \mathrm{mm}$ tip electrode. 


\section{Introduction}

Radiofrequency (RF) ablation of type I atrial flutter ( $A F L$ ) has a high procedural success $(>95 \%)^{1-6}$ and a low recurrence rate $(6-9 \%)^{3,5.7}$ after documentation of bidirectional isthmus conduction (BIC) block. However, there are concerns with temperature-guided ablation using a 4-mm tip RF catheter. These include the necessity of multiple RF pulses with creation of potentially proarrhythmic "skip" lesions, extent of myocardial damage following multiple and prolonged RF pulse delivery, and long fluoroscopy and procedure times. Experimental work suggests that the lesion size is greater with an 8-mm tip RF electrode and when a parallel electrode-tissue orientation is achieved, 8,10 However, to ensure tissue contact and to avoid coagulum formation, long ablation electrodes require better temperature monitoring." The available clinical experience with the use of a long tip RF electrode for AFL ablation is mostly observational. $1,2,4,5,12,13$ In the present study a new catheter design, an 8-mm split-tip electrode with 2 integrated themocouples, allowing independent temperature monitoring (Cerablate ${ }^{3}$ plus Flutter, Dr. Osypka GmbH, Grenzach-Wyhlen, Germany), was evaluated in a prospective randomized manner against a 4-mm tip electrode for ablation of type I AFL.

\section{Methods}

The clinical characteristics of 30 consecutive patients randomized to undergo ablation of the right atrial isthmus for type I AFL using either an 8-mm split-tip (group I) or a 4-mm tip (group II) RF electrode are summarized in Table 1. The concomitant atrial fibrillation was paroxysmal in 6 and persistent in 9 patients. Informed consent was obtained from every patient. Antiarthythmic drugs were discontinued at the time of study in 4 patients from group $I$ and in none from group II $(P=N S)$. Electrophysiologic study included documentation of BlC and endocardial activation sequence during AFL.'

The Cerablate plus Flutter RF catheter consists of two 4-mm electrodes spaced $0.5 \mathrm{~mm}$ apart such that they virtually form one $8 \mathrm{-mm}$ electrode if RF energy is delivered simultaneously through both electrodes (Figure 1). The dual thermocouple located on the inner side of the catheter curve monitors temperature from both electrodes. The feedback control in the RF generator takes both measured temperatures into consideration and the highest of the 2 temperatures "leads" the power delivery to both electrodes. The output is regulated so that power is delivered equally to both electrodes and that none of the 2 temperatures should exceed the target temperature significantly. 


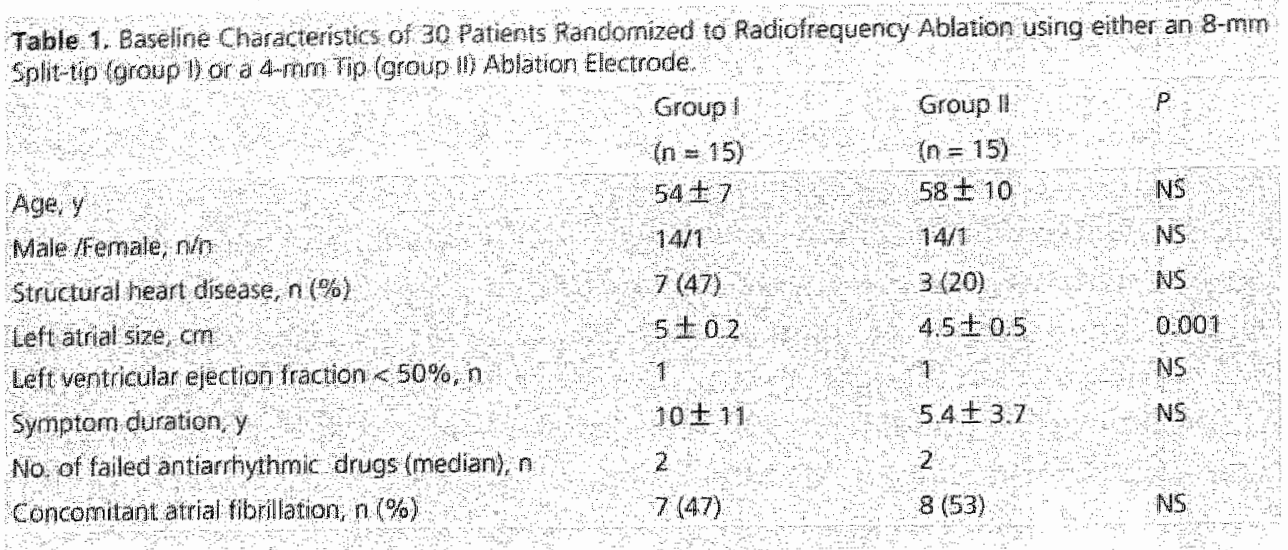

Patients from group I underwent ablation of the right atrial isthmus using an 8-mm split-tip ablation catheter. For patients randomized to group II, the same catheter was used as a $4-\mathrm{mm}$ tip electrode by disconnecting the proximal electrode from energy delivery. Each RF pulse was delivered for 90 seconds with a preset temperature of $55^{\circ} \mathrm{C}, 70 \mathrm{~W}$ as the cut off limit for power delivery and in unipolar mode. A HAT300Smart (Dr. Osypka GmbH, Grenzach-Wyhlen, Germany), $500 \mathrm{kHz}$ RF generator was used. A linear ablation of either posterior and/or septal right atrial isthmus was perfomed by delivering RF pulses point-by-point at sequential sites. Temperature, power and impedance curves from the RF generator were displayed in real time and guided optimal orientation of the RF catheter to obtain adequate electrode-tissue contact (Figure 2). Noninducibility of AFL (with 3 atrial extra-stinuli and incremental pacing up to $200 \mathrm{~ms}$ ) after demonstration of BIC block, the endpoint of procedure was also assessed following isoproterenol infusion $(1-3 \mu \mathrm{g} / \mathrm{min}),{ }^{6,14}$ Bidirectional isthmus conduction block was defined by observing reversal in activation sequence of the lateral right atrial wall during proximal coronary sinus pacing and craniocaudal activation of the atrial septum with activation of the proximal coronary sinus after His bundle activation during low lateral right atrial pacing. Fluoroscopy time was calculated as the total fluoroscopy time from first RF pulse to completion of the ablation procedure.

Patients were followed in the arrhythmia clinic and Holter recordings were performed at 8 weeks and subsequently at 3 -month intervals. Antiarrhythmic drug therapy was continued after successful RF ablation in patients with concomitant atrial Gbrillation $(n=15)$ and was stopped in patients with isolated AFI $(n=15) .6$ 


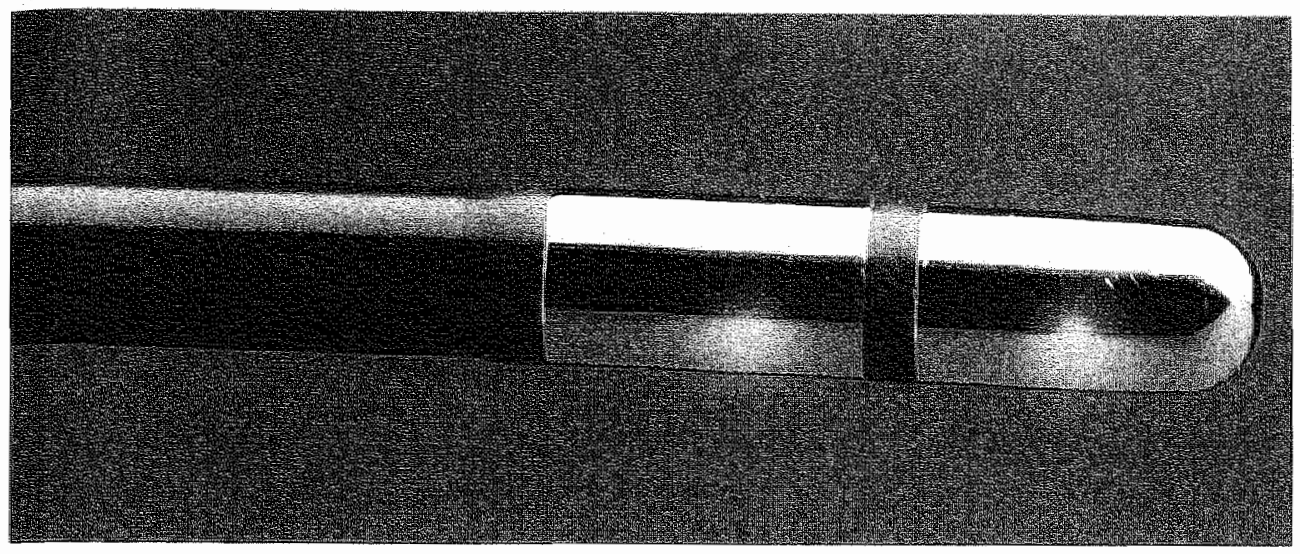

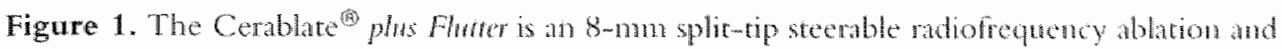
mapping catherer with 2 incegrated themocouples. The thenocouple, either distal or proximal. that records the highest remperature controls the power delvered. The anergy is delivered through both electrodes simuleneously. Bipolar electrograns atre recorded from the 2 distal tham electrodes.

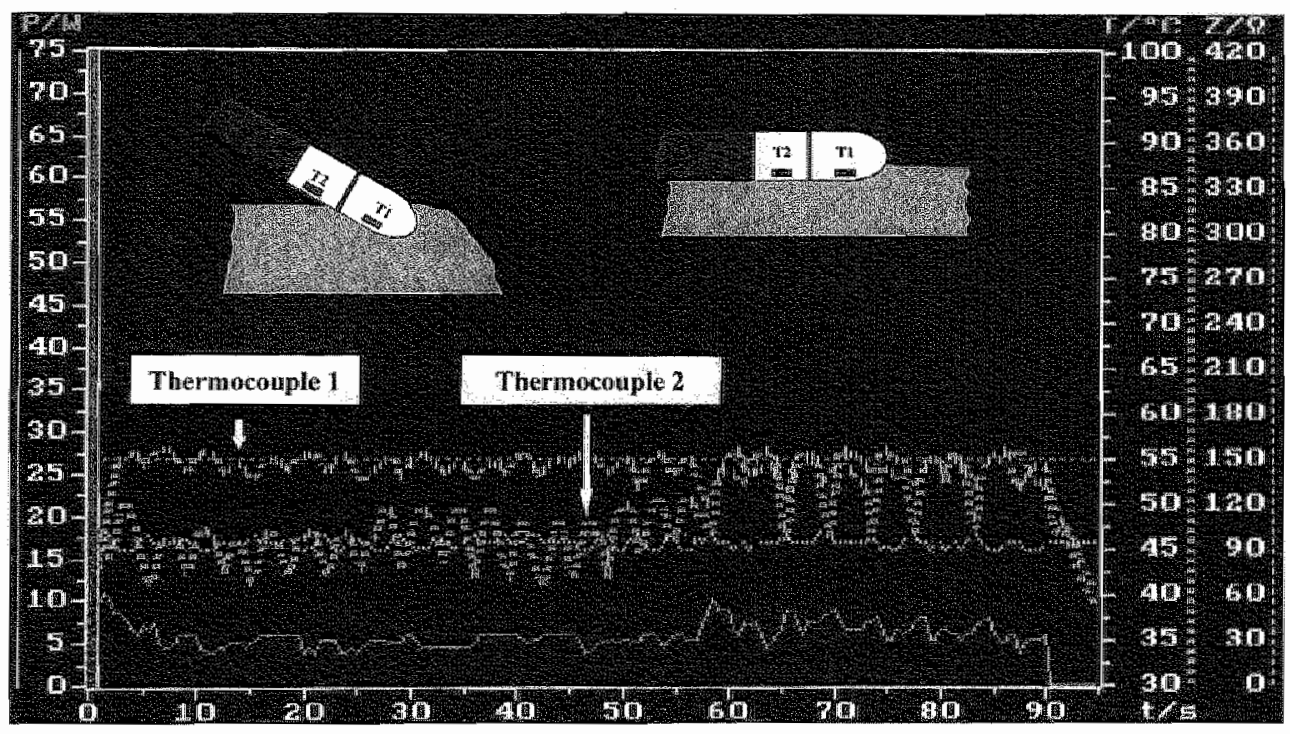

Figure 2. The value of dual themocoupes, distal (T) and prowmal (T2), in the Bum split-rip electrode to guide a maxinal tissue-dectrode contact. The graph shews the womperane (T) in blue and $T 2$ in pink color) power (in red color) and impedance (in yellow colks) curves oblance

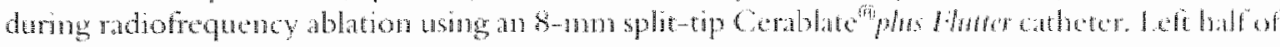

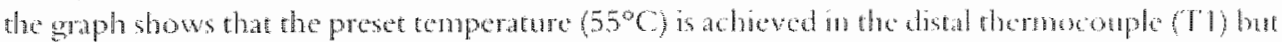

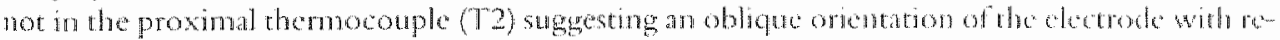

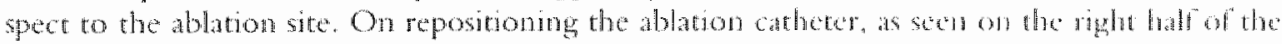

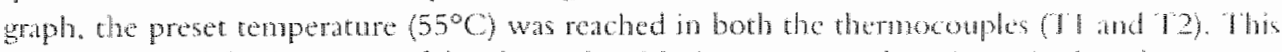
suggests a parallel ontentation of the cectrode with tiste contact along its cutire langeth. 
All data are expressed as mean \pm S.D, median and range. Mean values were compared by ANOVA and $\chi^{2}$ (or Fisher's exact) test was used for testing homogeneity in contingency tables. Results were considered to be significant at $5 \%$ critical level $(P<0.05)$.

\section{Results}

Table 2 compares the procedural variables in 2 study groups. Before RF ablation, AFL was not inducible in 10 patients. In the remaining 20 patients, a counterclockwise AFL was predominantly observed.

After RF ablation, noninducibility and BIC block were verified under isoproterenol infusion in all patients, except in 3 patients from group II. In the latter 3 patients, isoproterenol was not used because of sustained AF induced inadvertently earlier during the procedure, which required external cardioversion. However, persistence of BIC block was confirmed at least $1 / 2$ hour after delivery of the last RF pulse in each of these 3 patients. Before achieving proce dural success, a reversal of BIC block under isoproterenol infusion occurred in 4 patients ( 3 patients in group $I$ and 1 patient in group II) and required additional RF pulses. The acute success rate at the completion of the procedure was $100 \%$ For group I and $93 \%$ for group I1. A significantly fewer number of RF pulses [12 \pm 3.5 (median 11) in group $1 \mathrm{vs} 27 \pm 9$ (median 23) in group $11, p<0.0001$ ] were required to achieve success when using an $8 \mathrm{~mm}$ split-tip catheter. Also, the mean fluoroscopy time $(23 \pm 13 \mathrm{~min}$ in group I vs $45 \pm 28 \mathrm{~min}$ in group II, $P=$ $0.01)$ was shorter when ablation was performed using an $8-\mathrm{mm}$ split-tip catheter. However, the mean procedure time remained comparable in both groups. There were no procedure-related complications.

Biophysical parameters recorded during the RF ablation procedure in both groups are presented in Table 3 . A preset temperature $\left(55^{\circ} \mathrm{C}\right)$ was achieved using both electrode sizes. A higher mean power (group I, $44 \pm 15 \mathrm{~W}$ vs group $11,26 \pm$ $11 \mathrm{~W}, \mathrm{P}<0.0001$ ) and a lower mean impedance (group 1,72 $44 \Omega$ vs group 11,97 $\left.\pm 7 \Omega, p^{*}<0.0001\right)$ was noted with the $8-\mathrm{mm}$ split-tip RF catheter, and no audible "pop" or carbonization of the catheter tip occurred. In 2 patients carbo- nization of the ablation electrode was noted while using a 4-mm tip ablation electrode.

A comparable mean follow-up was available in both groups (group I, $4.3 \pm$ 2.8 and group $11,4.8 \pm 2$ months, $\mathrm{P}=\mathrm{NS}$ ). Antiarrhythmic drugs were continued in all patients with a concomitant atrial fibrillation, except 1 . No patient in group I had an AFL recurrence. One patient in group II had recurrence of AFL at 5 months after RF ablation. Successful re-ablation required 7 RF pulses using an 8-num split-tip catheter. 


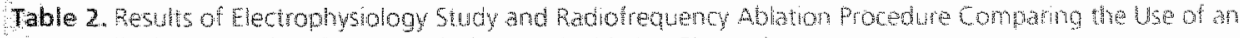

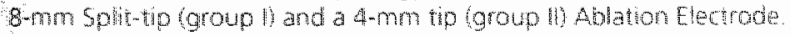

\begin{tabular}{|c|c|c|c|}
\hline & $\begin{array}{l}\text { Goup } \\
\text { hy }=15\}\end{array}$ & $\begin{array}{l}\text { Group } \\
\text { an }=15 y\end{array}$ & p \\
\hline \multicolumn{4}{|l|}{ Iritid rhythn during the sudy $n$ (\%) } \\
\hline mcessant $A F$ & $5(33\}$ & $7(4)$ & \multirow[t]{2}{*}{ N5 } \\
\hline Sinus & $10(67)$ & $8(53)$ & \\
\hline Afl induced n & 5 & 3 & N5 \\
\hline ArL yde lergth, ms & $232 \pm 34$ & $264 \pm 25$ & 0.007 \\
\hline \multicolumn{4}{|l|}{ Rotation of AFE: } \\
\hline Documented founterclockwiselockwisel, rim & $10[10 / 0]$ & $10|9 / 2|$ & \multirow[t]{2}{*}{ NS } \\
\hline Not dowmented n $(\%)$ & $5(33)$ & $5(33)$ & \\
\hline \multicolumn{4}{|l|}{ Rhythm churing radhofrequency ablation, n $\%$} \\
\hline Coronay sinus pacing & $8(53)$ & $10(67)$ & \multirow[t]{3}{*}{ NS } \\
\hline AFL & $3(20)$ & $4(27)$ & \\
\hline Bom & $4(27)$ & $1(6)$ & \\
\hline \multicolumn{4}{|l|}{ Right atrial isthmus ablated, $n(\%)$} \\
\hline Posterior & $11(73)$ & $12(80)$ & \multirow[t]{3}{*}{ NS } \\
\hline Sepizal & $2\{13.5\}$ & 0 & \\
\hline Both & $2(13.5)$ & $3(20)$ & \\
\hline Acute procedural success, $n(\%)$ & $15(100)$ & $14(93)$ & NS \\
\hline \multicolumn{4}{|l|}{ Radiofrequency pulses procedure, in } \\
\hline Mean & $12 \pm 3.5$ & $27+10$ & \multirow[t]{3}{*}{$<0.0001$} \\
\hline Median & 11 & 23 & \\
\hline Range & $\langle 5-22\rangle$ & $(15-42)$ & \\
\hline Procedure the (min) & $162+35$ & $179 \pm 48$ & NS \\
\hline Fluoroscopy time (min) & $23 \pm 13$ & $45 \pm 28$ & 0.01 \\
\hline
\end{tabular}

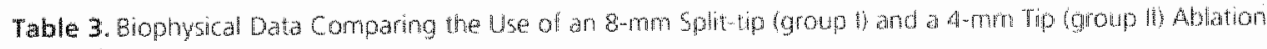
slectrode.

Mean power, W

Meon impedance, $\Omega$

Mean lotal energy W-ser

$\begin{array}{lll}\text { Group } 1 & \text { Group } & p \\ n=15) & (n=15) & \\ 44 \pm 15 & 25 \pm 11 & <0.0001 \\ 72 \pm 4 & 97 \pm 7 & <0.0001 \\ 55,790 \pm 23,137 & 51,477 \pm 21,768 & \text { MS }\end{array}$

U1

$51,477 \pm 21,768$ 


\section{Discussion}

We evaluated in a randomized study the use of an 8- $\mathrm{mm}$ split-tip steerable RF ablation catheter incorporating dual thermocouples (Cerablate ${ }^{3}$ plus Flutter, Dr. Osypka GmbH) for ablation of type I. AFL and compared the results to ablation using a 4-mm tip catheter. Ablation of the right atrial isthmus was performed using a 90 -second RF pulse delivered point-by-point at sequential sites with a preset temperature of $55^{\circ} \mathrm{C}$. Noninducibility of AFL and BIC block under isoproterenol infusion was used to document procedural success. When compared with ablation using a 4-mm tip catheter, an equally high procedural success could be achieved with the $8-\mathrm{mm}$ split-rip catheter. These results compare favorably with the previously reported small nonrandomized experence using long tip ablation catheters $(6-, 8$ - or 10 -mm) $1,2,4,5,12,13$ when compared with the 4-mm tip catheter, a higher mean power and a lower mean impedance were recorded using the 8 -mm split-tip catheter. This is in accordance with information from experimental studies where a direct relation of electrode surface area to mean power and an inverse relation to mean impedance was shown.8

In contrast to the 4-mm electrode, successful right atrial isthmus ablation using the 8 -mm split-tip electrode required significantly less RF pulses and shorter mean fluoroscopy time. In studies reporting $>98 \%$ acute success, as judged by the demonstration of BIC block, varying number of RF pulses were required: median $6(9 \pm 7)$ by Poty at al, "median $3(5.8 \pm 5.5$, range $1-21)$ by Nakagawa et al, ${ }^{2} 8 \pm 5$ (range, $2-43$ ) by Schumacher et al, ${ }^{3} 2.3 \pm 0.8$ (range, 1 4) by lesaka et al, ${ }^{4}$ median $12(14 \pm 8)$ by Paydak et al, ${ }^{5}$ and $6 \pm 3$ by Tail et all. ${ }^{7}$ Although the method of RF ablation, cited in these reports, was anatomical and directed at obtaining a line of BIC block, the technique of delivering sequential RF pulses differed. The sequential delivery of RF applications has been variously described as; "progressively withdrawn with sequential stops", "a single continuous application", "linear drag", "sequential lesions with stepwise withdrawal" and "continuous application during pull back of catheter" more, a 4-, 6- or 8-mm tip RF catheter was used. ${ }^{1-6,12,13}$ The ablation parameters were not uniform; energy was delivered in a power mode (30 to 60 W) 1,2,5 or temperature mode (with a high preset temperature, $\left.70^{\circ} \mathrm{C}\right)^{1,3.7}$ mode, with diftering duration of the individual RF pulse (15 to 120 seconds). $1-5,7$ Unlike the previous studies, $1-5,7$ isoproterenol was used to determine acute procedural success in this study. These differences in methodology may have an important intluence on the count of R F pulses required for procedural success and therefore a comparison of the present study with those previously reported is invalid. 


\section{Conclusion}

Linear ablation of the right atrial isthmus can be performed using an $8-\mathrm{mmm}$ split-tip RF catheter with an high success rate comparable to a 4-mm tip RF catheter. However, fewer RF pulses and shorter fluoroscopy time supports preference of an 8-mm split-tip RF catheter over a 4-mm tip RF catheter for ablation of type I AFL.

\section{References}

1. Poty H, Saoudi N, Nair M, Anselme F, Letac B. Radiofrequency catheter ablation of atrial flutter: further insights into the various types of isthmus block: application to ablation during sinus rhythm. Circulation 1996;94:3204-3213.

2. Nakagawa $H$, Lazzara $\mathbb{R}$, Khastigir T, Beckman K, McClelland JH, Imai S, Pitha JV, Becker AE, Arruda M, Gonzalez MD, Widman LE, Rome M, Neuhauser J, Wang X, Calame J, Goudeau MD, Jackman WM. Role of tricuspid annulus and the eustachian valve/ridge on atrial flutter. Relevance to catheter ablation of the septal isthmus and a new technique for rapid identification of ablation success. Circulation 1996;94:407-424.

3. Schumacher B, Pfeiffer D, Tebbenjohanns J, Lewalter T, Jung W, Liideritz B. Acute and long-term effects of consecutive radiofrequency applications on conduction properties of the subeustachian isthmus in type I atrial flutter. I Cardiowase Electrophysiol 1998;9:152-163.

4. Iesaka Y, Takahashi A, Goya M, Yamane T, Tokunaga T, Amemiya H, Fujiwara $H$, Nitta J, Nogami A, Aonuma $\mathbb{K}$, Hiroe M, Marumo F, Hiraoka M. High energy radiofrequency catheter ablation for common atrial flucter targeting the istlumus between the inferior vena-cava and tricuspid valve anmulus using a super long tip electrode. Paing Clin Electrophysiol 1998;21:401-409.

5. Paydak H, Kall JG, Burke MC, Rubenstein D, Kopp DE, Verdino RJ, Wilber DJ. Atrial fibrillation after radiofrequency ablation of type I atrial flutter. Time to onset, determinants and clinical course. Circulation 1998;94:3204-3213.

6. Nabar A, Rodriguez LM, Timmernans C, vd Dool A, Smeets JLRM, Wellens HJJ. Effect of riglat atrial isthmus ablation on the occurrence of atrial fibrillation: observations in four patient groups having type I atrial flutter with or without associated atrial fibrillation. Circulation 1999:11:1441-1445.

7. Tai CT, Chen SA, Chiang CE, Lee SH, Wen ZC, Huang J, Chen YJ, Yu WC, Feng AN, Lin YJ, Ding YA, Chang MS. Long-term outcome of radiofrequency catheter ablation for typical atrial flutter: risk prediction of recurrent arrhythmias. J Cardiovase Electrophysiol 1998;9:115-121. 
8. Langberg Jy, Gallagher M, Strickberger A, Amirana O. Temperature-guided radiofrequency catheter ablation with very large distal electrodes. Circulation $1993 ; 88: 245-249$.

9. Otomo $\mathbb{K}$, Yamanashi WS, Tondo C, Antz M, Bussey J, Pitha JV, Arruda M, Nakagawa $H$, Wietkampf FHM, Lazzara R, Jackman WM. Why a large tip electrode makes a deeper tadiofrequency lesion: Effects of increase in electrode cooling and electrode-tissue interface area. J Cardiovase Electrophysiol 1998;9:47-54.

10. Chugh SS, Chan RC, Johnson SB, Packer DL. Catheter tip orientation affects radiofrequency ablation size in the canine ventricle. Pacing Clin Electrophysiol 1999;22:413-420.

11. McRury ID, Panescu D, Mitchell M, Haines D. Nonuniform heating during radiofrequency catheter ablation with long electrodes. Monitoring the edge effect. Circtlation 1998;96:4057 4064.

12. Phillipon F, Plumb VJ, Epstein A, Kay GN. The rask of atrial fibrillation following radiofrequency catheter ablation of atrial futter. Circulation 1995;92:430-435.

13. Lesh MD, van Hare GF, Epstein LM, Fitzpatrick AP, Scheinman M, Lee R.J, Kwatsman A, Grogin HC, Griffin JC. Radiofrequency catheter ablation of atrial arrhythmias. Results and mechanisms. Circulation 1994;89;1074-1089.

14. Nabar A, Rodriguez LM, Timmemans C. Smeets JLRM, Wellens HJJ. Isoproterenol to evaluate resumption of conduction following right atrial isthmus ablation in type I atrial flutter. Circuation 1999;99:3286-3291. 


\section{Isoproterenol to evaluate resumption of conduction after right atrial isthmus ablation in type I atrial flutter}

Ashish Nabar, MD; Luz-Maria Rodriguez, MD; Carl Timmermans, MD; Joep L.R.M. Smeets, MD and Hein J.J. Wellens, MD.

Department of Cardiology, Academic Hospital Maastricht. 


\section{ABSTRACT}

Background: After radiofrequency (RF) ablation of atrial flutter (AFL) the demonstration of bidirectional isthmus conduction (BIC) block is considered the hallmark of a successful procedure. The purpose of our study was to test the persistence of BIC block after isoproterenol administration and to evaluate the importance of this finding with regard to AFL recurrences.

Methods: Radiofrequency ablation of AFL was performed in 44 consecutive patients with type I AFL by al linear ablation of the posterior isthmus ( $n=29$ patients), septal isthmus ( $n=4$ patients), or both right atrial (RA) isthmi ( $n=11$ patients). The procedural end point was complete BIC block and noninducibility of $A F L$. In case of noninducibility and apparent BIC block, the pacing protocol was repeated under isoproterenol infusion ( 1 to $3 \mu \mathrm{g} / \mathrm{min}$ ).

Results: Reversal of apparent BIC block accurred in 7 (15.9\%) of 44 patients. Six patients had bidirectional and 1 had unidirectional resumption of isthmus conduction. Counterclockwise AFL could be reinduced in 4 of these patients. Two to 24. (median, 4) additional RF applications were required to achieve a permanent $B / C$ block. At a mean follow-up of $7.3 \pm 7.6$ months (range, 2 to 31 months), $2(4.5 \%$ ) of 44 patients had AFL recurrences

Conclusions: Partial linear RF ablation could possibly aggravate the preexisting nonuniform anisotropic conduction in the RA isthmus, resulting in profound conduction slowing and apparent BIC block. Isoproterenol can unmask apparent BIC block. thus providing an opportunity to assess the possibility of reversal of BKC block and completeness of isthmus ablation during the same procedure. The low incidence $(4.5 \%)$ of AFL recurrences at follow-up suggests that noninducibility and BIC block under isoproterenol infusion may be a better endpoint for successful AFL ablation. 


\section{Introduction}

Linear ablation of the right atrial (RA) isthmus is an effective and curative therapy for type I atrial flutter (AFL). ${ }^{1}$ Presently, complete elimination of bidrectional isthmus conduction (BIC) is accepted as the best marker of long-term success. ${ }^{1,2}$ Atrial flutter recurrences are associated with failure to achieve complete BIC block at conclusion of the ablation procedure. ${ }^{3}$ Repeat electrophysiologic studies in patients with an AFL recurrence show regression or complete disappearance of isthmus conduction block. "Therefore, certainty of presence of permanent complete BIC block is essential. Use of isoproterenol in evaluating success, defined as noninducibility of AFL and BIC block, after radiofrequency (RF) ablation of AFL has not been reported previously.

\section{Methods}

Forty four consecutive patients who underwent RF ablation of type I AFL for multiple symptomatic episodes were included in the study (Table 1). At the time of RF procedure, 31 patients were taking either class IC $(n=22)$, class III ( $\mathrm{n}$ $=8$ ), or combination $(n=1)$ antiarrhythmic drug (AAD) therapy. Fifteen (34\%) of the 44 patients taking class IC therapy developed AFL while being treated for atrial fibrillacion (AF), the so called class IC atrial flutter. ${ }^{*}$ The ablation procedure was performed with the patient in a postabsorptive state after informed written consent was obtained. Bidirectional isthmus conduction, both anterograde and retrograde, was documented (Figure 1, A and B), and AFL was induced. In every patient, including patients with class IC AFL, the atrial endocardial activation sequence was suggestive of RA macro-reentry. No entrainment studies were performed. The ablation technique involved point-by-point sequential, 90 second RF applications with the temperature preset to $55^{\circ} \mathrm{C}$ (Osypka HAT 3005 ) or $70^{\circ} \mathrm{C}$ (Stockert Gmbh EP Shuttle generator) while the ablation catheter was progressively withdrawn across the RA isthmus under fluoroscopic guidance. A second RF application was delivered at a particular RA isthmic site unless a significant reduction in amplitude of the local atrial electrogram $(<25 \%)$ was observed. We validated BLC block by pacing altemately from the coronary sinus (CS) and low lateral RA at a 600 or $500 \mathrm{~ms}$ constant cycle length ${ }^{5}$. A retrograde isthmus conduction block was defined by an entirely craniocaudal activation of the lateral RA wall during proximal CS (CS7.8) pacing with terminal activation of the Halo1.2 bipoles and prolongation of the CS7.8 - Halo 1.2 interval (Figure 1C). An anterograde isthmus conduction block was defined by cauclocranial activation of the lateral RA wall and craniocaudal activation of the atrial septum with 


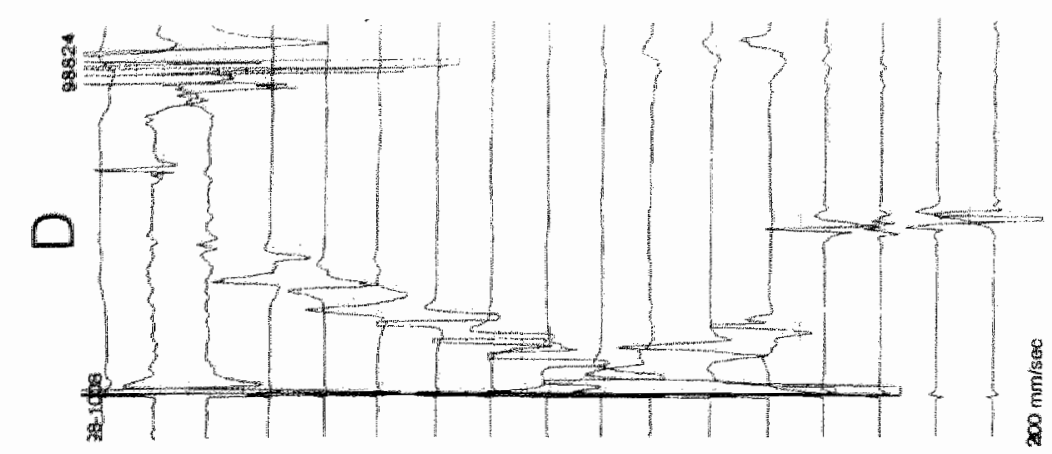

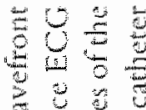
解 $\frac{2}{5} \frac{\pi}{8}$ $0 \div 0$ 월 $=0$

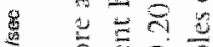
8 놀

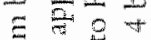

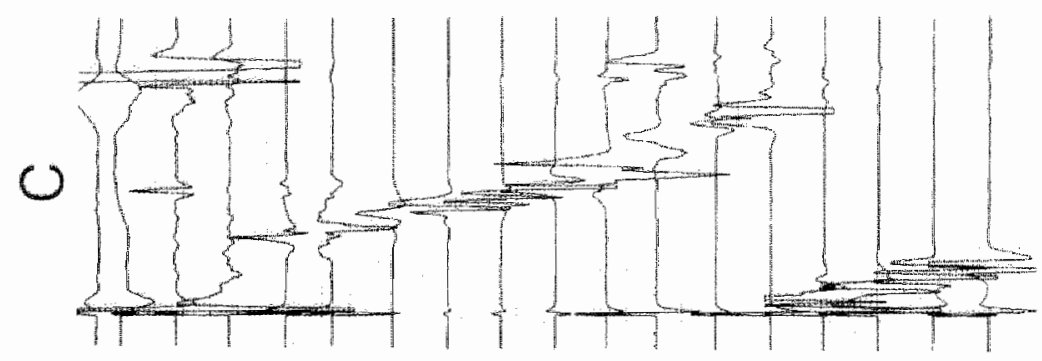

$\Xi \mathrm{v}$ $\pm \equiv$ $32 \frac{5}{3}$ $\leq 2=\infty$ $\leq F$ कo 5 政 330

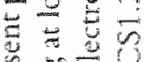
o 0 5.5

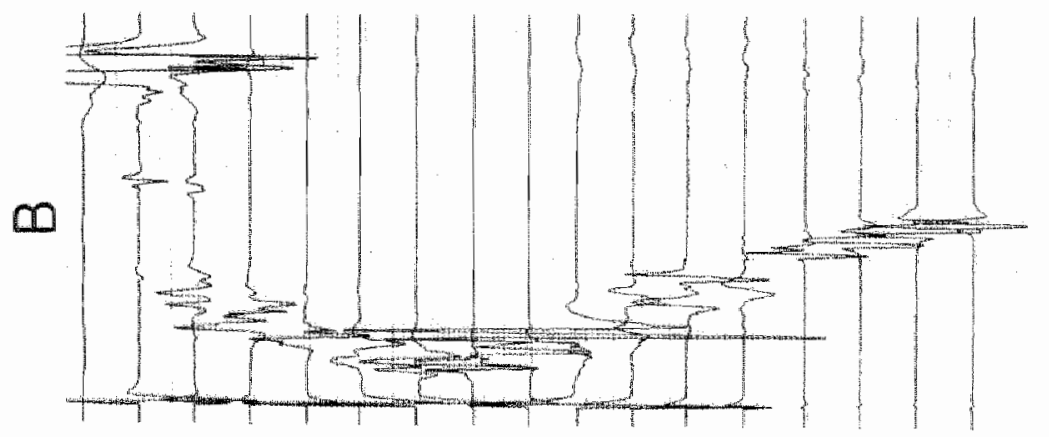

2303

$\underline{2} \underline{2}$

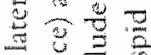
3 อ 5. $\because 0 \mathrm{~g}$

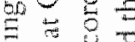
8 o

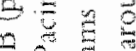
已

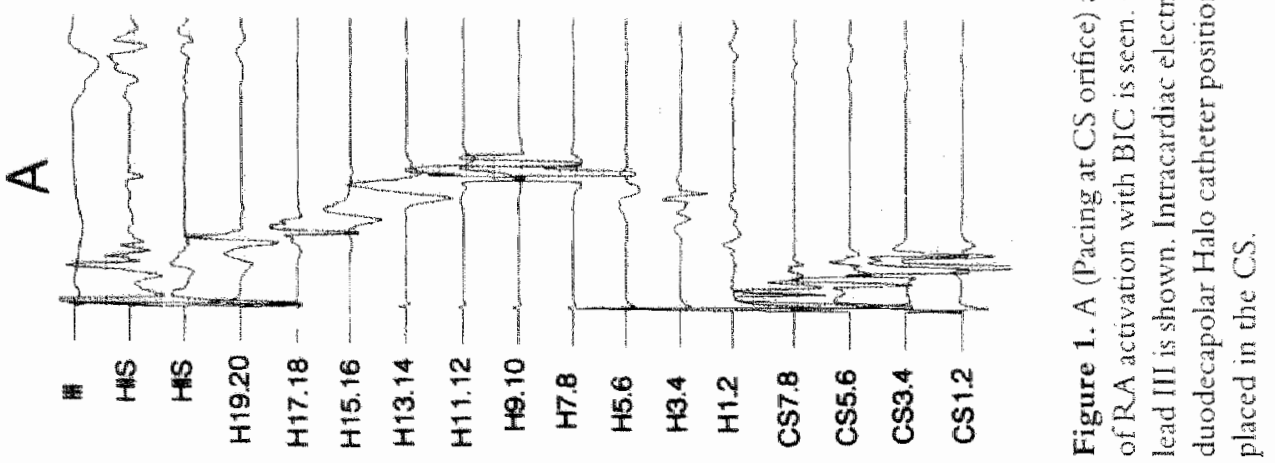


Table 1 . vaseline characterstics of the 44 Patents sudied

\begin{tabular}{|c|c|}
\hline Age, $y, 3$ & $55 \pm 13$ \\
\hline Malerenale, nh & $39 / 5$ \\
\hline Mean duraton of atrallututer, $y$ & $5 \pm 53$ \\
\hline \multicolumn{2}{|l|}{ Additional cardiac disease } \\
\hline Coronary attery disease & 1 \\
\hline Tachycardiomyopathy & \\
\hline status after arial septal defect repair & 1 \\
\hline Left atrial sizk, $\mathrm{cm}$ & $45 \pm 04$ \\
\hline Number of talled AADs, median (range) & $2(9-6)$ \\
\hline
\end{tabular}

terminal activation of CS7.8 after activation of the His bundle during low lateral RA pacing (Figure 1D). After apparent BIC block and noninducibility of AFL was obtained, the atrial pacing protocol (up to 3 atrial extrastimuli at 3 pacing cycle lengths and incremental atrial pacing) was repeated under isoproterenol infusion ( 1 to $3 \mu \mathrm{g} / \mathrm{min}$ ). In case of reinduction of $\mathrm{AFL}$ or resumption of isthmus conduction under isoproterenol infusion, further RF applications were delivered. The procedural endpoint was the demonstration of $\mathrm{BIC}$ block and noninducibility of AFL under isoproterenol infusion.

Post-ablation protocol: Twenty-four-hour Holter monitoring was done before discharge. Patients were followed up in the arrhythmia clinic at 8 and 12 weeks and thereafter at 3 -month intervals. Holter recordings were performed at 8 and 12 weeks and additionally when symptoms suggested a recurrence. Alf patients with concomitant $A F$, including patients with class $I C A F L$, received AADs after ablation of the RA isthmus. At follow-up, depending on the incidence of AF recurrences, an attempt was made to discontinue AADs. "However, patients with ablation of class $I C$ AFL continued to receive propafenone or flecainide. ${ }^{4}$

Statistical analysis: All data are expressed as mean \pm S.D or median and range.

\section{Results}

Electrophysiologic study and RF ablation: Details of the electrophysiological study and RF ablation procedure are summarized in Table 2 . The mean AFL cycle length was $250 \pm 41 \mathrm{~ms}$, and a counterclockwise rotation AFL was predominantly documented. Radiofrequency applications were delivered during CS pacing $(n=26$ patients), $\operatorname{AFL}(n=11$ patients), or during both $(n=7$ 


\begin{tabular}{|c|c|}
\hline Arl cycle length, $\mathrm{ms}$ & $250 \pm 4$ \\
\hline \multicolumn{2}{|l|}{ Rotation $A F, n$} \\
\hline Counterclodwise & 39 \\
\hline Clockwise & 2 \\
\hline Bowh & 3 \\
\hline \multicolumn{2}{|l|}{ Rhy thrn during RFA $n$} \\
\hline Cs pring & 26 \\
\hline$+4 C$ & 11 \\
\hline Both & 7 \\
\hline \multicolumn{2}{|l|}{ A A sthmus ablated, $n$} \\
\hline Posterlor & 29 \\
\hline Septal & 4 \\
\hline Both 1 Pै। & 11 \\
\hline Brpulses progecture median (ronge) & $24(4-43)$ \\
\hline Mean fluoroscopy tme, mules? & $46 \pm 20$ \\
\hline Meain proceduie time min & $192 \pm 51$ \\
\hline Mean follows up duration, no & $73 \pm 76$ \\
\hline Al recurrences $\cap(\%)$ & $2(4.5)$ \\
\hline
\end{tabular}

patients) rhythms. Twenty-nine patients had linear ablation of the posterior isthmus. In 11 patients, additional ablation of the septal isthmus was performed. Ablation of the septal isthmus alone was done in 4 patients. In all patients, noninducibility of AFL and apparent BIC block was demonstrated.

Under isoproterenol infusion, noninducibility of AFL and BIC block persisted in 37 patients. Seven patients (15.9\%) showed a reversal of BIC block. In these 7 patients, resumption of BIC under isoproterenol infusion was noted $23 \pm$ 11 minutes after the last RF application that showed apparent BIC block. In 6 patients, resumption of isthmic conduction was bidirectional (Figure 2). In 3 of these patients, a counterclockwise AFL was reinduced, whereas short runs of clockwise AFL were induced in 2 of the other 3 patients. The remaining patient had persistent retrograde isthmus conduction block, but counterclockwise AFL. could be induced, which suggests an unidirectional resumption of isthmus conduction (Figure 3 ). In the 4 parients with re-inducible AFL, the mean AFL cycle length prior to RF ablation was $240 \pm 8 \mathrm{~ms}$. The reinduced AFL was sustained but slower, with a mean cycle length of $285 \pm 60 \mathrm{~ms}$. Four (median) additional RF applications (range, 2 to 24 ) were required to obtain complete and permanent BIC block. These additional RF applications were delivered at the same RA isthmi as those resulting in apparent BIC block. 

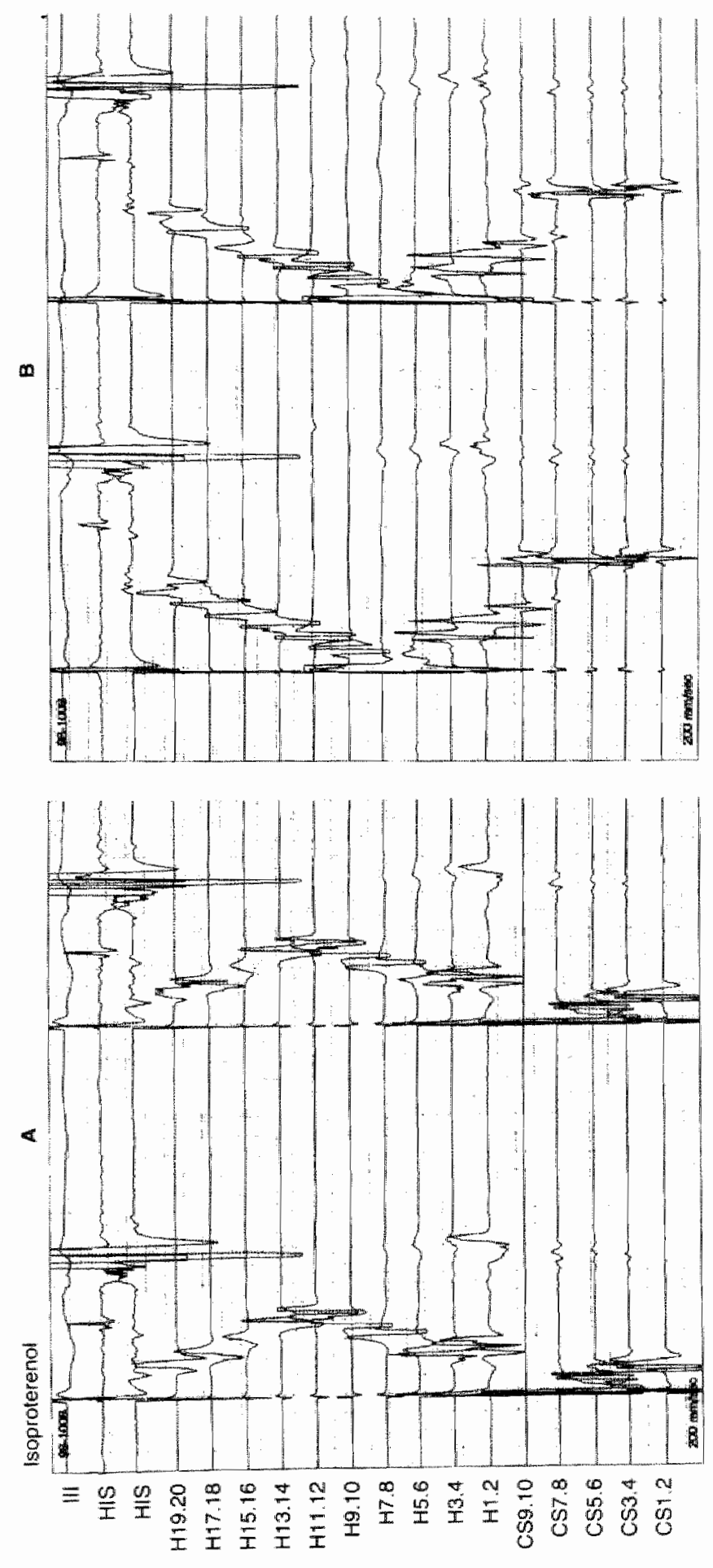


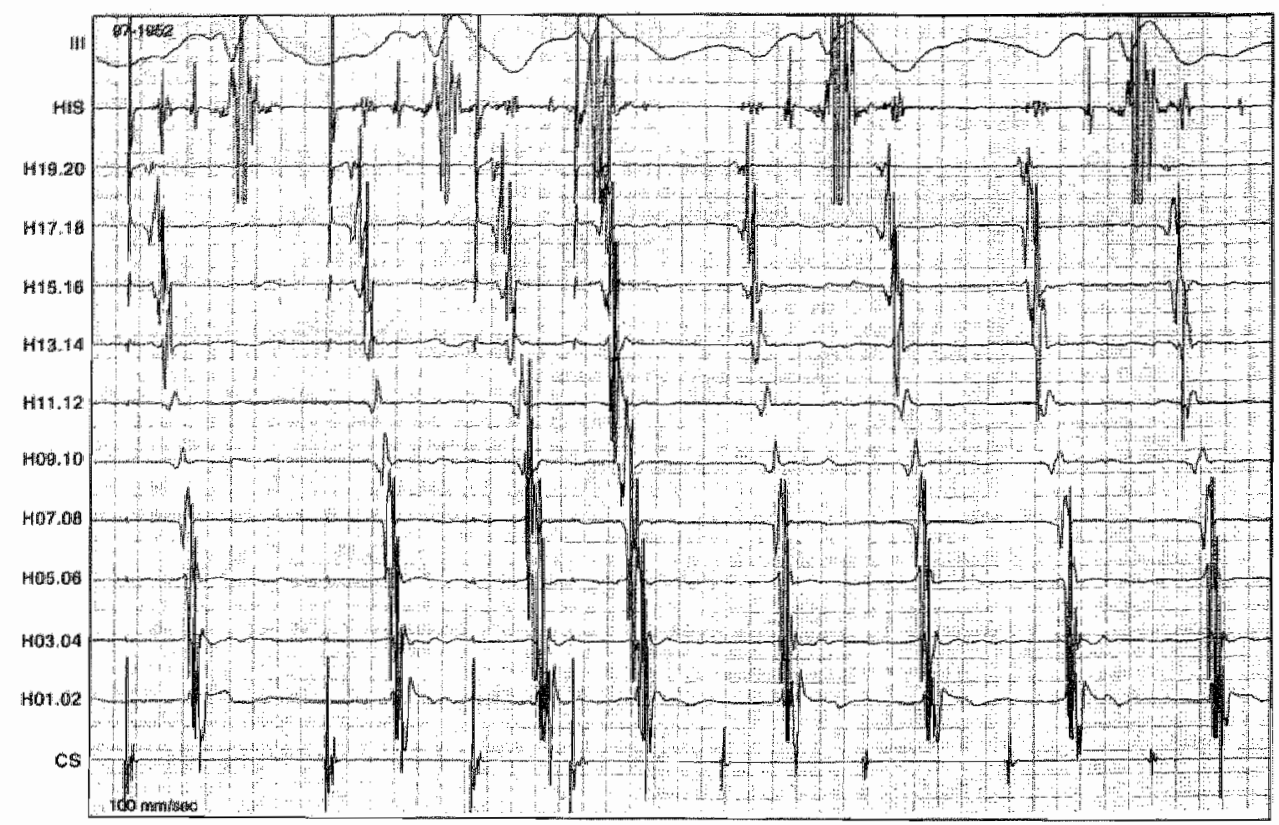

Figure 3. Example of unidirectional resumption of isthmus conduction after isoproterenol infusion. $\mathbb{R}$ ecordings abtained during CS pacing in sinus thythm. First 2 paced beats ( $430 \mathrm{~ms}$ interval) are last beats of the basic 10-beat drive. Note single wave front of RA actiwation, implying retrograde isthmus conduction block. Two extrastimuli are delivered at $300 \mathrm{~ms}$ and $210 \mathrm{~ms}$. Second extrastimulus initiated a sustained counterclockwise AFL (cycle length, 290 ms), indicating resumption of anterograde isthmus conduction.

Procedural success was achieved in a single session in every patient after a total 24 (median; range, 4-43) RF applications. Mean procedure duration was $192 \pm 51$ minutes with a mean fluoroscopic time of $46 \pm 20$ minutes.

Follow-up: Follow-up (mean of $7.3 \pm 7.6$; range, 2 to 31 months) was available in all patients. At the time of the last follow-up visit, 29 patients were receiving $A A D$ s for AF recurrences. Two patients had an AFL recurrence at 3 and 7 months after the procedure, respectively, in spite of documentation of persistent BIC block under isoproterenol. During a second procedure, both patients were found to have BIC delay, suggesting regression of isthmus block. Both patients underwent a stucessful repeat ablation and were free of AFL recurrences at the last follow-up 8 and 10 months later, respectively. 


\section{Discussion}

The RA isthmus is a slow conduction zone. The tricuspid annulus and crista terminalis are the anterior and posterior barriers of the AFL reentrant circuit that are impervious to transversal conduction. ${ }^{8}$ Morphological studies of the RA isthmus by Cabrera et al $^{9}$ revealed a typical oblique orientation of the subendocardial myocardial fibers in $57 \%$ of their normal heart specimens, with a narrow zone of intersection of the subendocardial fibers in $79 \%$. Fiber ortentation and direction of excitation are important determinants of nonuniform anisotropy ${ }^{10}$ and could provide a basis for clinical AFL. The use of class IC or III AADs in $70.5 \%$ patients in the present study could have worsened the preexisting nonuniform anisotropy in the RA isthmus. "Radiofrequency energy application causes focal necrosis, which may not always be transmural considering the variation in thickness of the RA isthmus ( 3 to $6 \mathrm{~mm}$ ). ${ }^{9}$ Microscopically, there is a loss of side-to-side connections between groups of fibers and intercellular clefts with shrinkage of contractile elements. ${ }^{12}$ Presumably, an incomplete ablation of the RA isthmus aggravates preexisting nonuniform anisotropy and slows the conduction velocity further. ${ }^{3}$ "The low effective conduction velocity through the RA isthmus can make it difficult to distinguish between slow conduction and conduction block. ${ }^{13,14}$ The decremental nature of the nonuniform anisotropic conduction is greatest at slower pacing cycle lengths, ${ }^{1.3}$ as were used 600 and 500 ms) to validate the BIC block. We believe that the initial apparent BIC block noted in 7 patients (15.9\%), who showed a reversal of BIC block under isoproterenol infusion, represents profound conduction slowing in the partially ablated isthmus and not failure of impulse conduction. Both class I and III AADs are known to preferentially slow the isthmus conduction, particularly in the setting of nonuniform anisotropy, "and could have contributed to apparent BIC block in 4 patients who were taking AADs (amiodarone, sotalol, and flecainide) during the study. However, 27 (72.9\%) of the 37 patients, who did not show reversal of $B i C$ block were also taking these type of $A$ ADs. Recent sudies advocate monitoring the amplitude of local electrograms at ablation site and double potentials along the ablation line ${ }^{15,16}$

Isoproterenol, via its $\beta$ adrenergic stimulating action, increases the level of intracellular cyclic AMP. ${ }^{17}$ This will decrease the intercellular resistancels and increases the rate of rise of the zero phase of the action potential, ${ }^{16}$ thereby increasing conduction velocity in the AV node, the atria, and the ventricles. ${ }^{20}$ Repetition of the post ablation pacing protocoll under isoproterenol (1 to 3 $\mu g / m i n)$ infusion, at the same or faster pacing cycle lengths as at baseline, resulted in reversal of apparent $B 1 C$ block in 7 (15.9\%) of 44 patients. In 6 paticnts, there was an evidence to suggest resumption of BIC. In 3 of these 6 , a counterclock- 
wise AFL was reinduced, and in addition short runs of clockwise AFL were induced in 2 of the remaining 3 patients. The remaining patient had a persistent retrograde isthmus conduction block but an inducible counterclockwise AFL, suggesting an unidirectional resumption of isthmus conduction. These findings imply an improvement in velocity of impulse conduction and an increase in the safety factor for impulse propagation in the incompletely ablated isthmus. In canine myocardial tissue, isoproterenol has been shown to improve the conduction velocity in case of nomuniform anisotropy. ${ }^{21}$ Thus, isoproterenol can unmask: an apparent BIC block by improving conduction velocity in the incompletely ablated isthmus.

After a mean follow-up of $7.3 \pm 7.6$ months (range, 2 to 31 months), $2(4.5 \%)$ of 44 patients had a recurrence of AFL at 3 and 7 months after ablation, respectively. At the last follow-up, 29 patients were receiving AADs for AF recurrences. After demonstration of noninducibility of AFL and BIC block, an AFL recurrence rate of 6 to $9 \%$ is reported, with the majority of recurrences occurring within the initial 6 months after ablation. ${ }^{2,3}$ The low AFL recurrence rate in the present study provides evidence that demonstration of noninducibility of AFL and BIC block under isoproterenol infusion may be a better end point after RF ablation of AFL. However, the recurrence of AFL in 2 patients despite documentation of BIC block under isoproterenol indicates a small risk of reversal of BIC block over time.

\section{Study Lïmitations}

Our explanation of profound conduction slowing in the nomuniformly anisotropic RA isthmus after RF ablation as the cause of an apparent BIC block should be proven by detailed mapping of the RA isthmus with recordings from a closely spaced multi-polar catheter ${ }^{22}$ or by the non-fluoroscopy CARTOTM system. ${ }^{23}$ Before isoproterenol is used, pacing close to the line of block may be attempted as another method to detect persistent slow conduction in the incompletely ablated isthmus. However, despite these efforts to validate $\mathrm{BIC}$ block, conduction may still persist through deeper (epicardial) fibers surviving below the ablated endocardial region. Currently, this may not be demonstrable, because methods to "check" conduction in this dimension (i.e, depth) with an adequate resolution do not exist for use in a clinical setting. During the procedure, a resumption of isthmus conduction may occur due to an improvement in conduction velocity purely as a function of time rather than isoproterenol. The time course of recovery has been reported to be within 30 minutes and sometimes 1 hour after the last RF application. ${ }^{24,25}$ In the present study, isoproterenol was 
used soon after demonstration of an apparent BIC block, and hence this question cannot be adequately addressed. However, the resumption of BIC $23 \pm 11$ minutes after the last RF application suggests that use of isoproterenol immediately may provide a means to more rapidly end the study.

\section{Conclusions}

Partial linear RF ablation could possibly aggravate preexisting nonuniformly anisotropic conduction in the RA isthmus, resulting in profound slowing of conduction and apparent BIC block. Isoproterenol can unmask apparent BIC block by improving conduction in the incompletely ablated isthmus. This provides an opportunity, importantly during the same procedure, to assess an early reversal of $\mathrm{BIC}$ block and completeness of isthmus ablation. The low $(4.5 \%)$ recurrence incidence of AFL reported in the present study suggests that noninducibility and BIC block under isoproterenol infusion may be a better endpoint of successful AFL ablation.

\section{References}

1. Poty H, Saoudi N, Aziz AA, Nair M, Letac B. Radiofrequency ablation of type I atrial flutter: prediction of late success by electrophysiological criteria. Ciralation 1995;92:1389-1392.

2. Schumacher B, Pfeiffer D, Tebbenjohanns J, Lewalter ' $T$, Jung W, Lüderitz B. Acute and long-term effects of consecutive radiofrequency applications on conduction properties of the subeustachian isthmus in type I atrial flutter. I Cardiomasc Electrphysiol 1998;9:152-163.

3. Tai CT, Chen SA, Chian CE, Lee SH, Wen ZC, Huang JL, Chen YJ, Yu WC. Feng AN, Lin YJ, Ding YA, Chang MS. Long-term outcome of radiofrequency catherer ablation for typical atrial flutter: risk of prediction of recurrent arrhythmias. J Cardionase Elcotrplysiol 1998:9:115-121.

4. Nabar A, Rodriguez LM, Timmermans C. Smeets JLRM, Wellens HJ]. Radiofrequency ablation of "class IC atrial tlutter" in patients with resistant atrial fibrillation. Am J Cardiol 1999; 83:785-787.

5. Poty H, Saoudi N, Nair M, Anselme F, Letac B. Radiofrequency catheter ablation of atrial flutter: further insights into the various types of isthmus block: application to ablation during sinus rhythm. Circulation 1996;94:3204-3213.

6. Nabar A, Rodriguez LM, Timmermans C, vd Dool A, Smeets JLRM, Wellens HJJ. Effect of right atrial isthmus ablation on the occurrence of atrial fibrillation: observa- 
tions in four patient groups having type I atrial furter with or without associated atrial fibrillation. Cirmation 1999:99:1441-1445.

7. Olshansky $\mathrm{B}$, Okumum K. Hess P. Waldo AL. Demonstration of an area of slow conduction in human atrial futter. J An Coll Cardiol 1990;16:1639-1648.

8. Olgin J, Kalman JM, Lesh MD. Conduction barriers in human atral flutter: correlation of electrophysiology and anatomy. J Cardionasc Electphysiol 1996;7:1112-1126.

9. Cabrera JA, Sanchez-Quintana D, Ho SY, Medina A, Anderson RH. The architecture of the atrial musculature between the orifice of the inferior caval vein and the tricuspid valve: the anatomy of the isthmus. I Cardowas Electrophysid $1998 ; 9: 186-1195$.

10. Hocini M, Loh P, Ho SY, Sanchez-Quintana D, Thibault B, de Bakker JM, Janse M]. Anisotropic conduction in the triangle of Koch of mammalian hearts: electrophysiologic and anatomio comelations. I Aw Coll Cardiol 1998;31:629-636.

11. Yamashia T, Inoue H, Nozaki A, Kuo TT, Usui M. Sugimoto T. Role of anisotropy in deternining the selective action of antiarthythmics in atrial flutter in dog. Cardiovase Res $1992: 26: 244-249$

12. Tabuchi T. Okumura K, Matsunaga T, Tsunoda R, Jougasaki M, Yasue H. Linear ablation of the isthmus between the inferior vena cava and tricuspid annulus for the treatment of atrial futer: study in the canine atrial flutter model. Circulation $1995 ; 92: 1312-1319$

13. Spach MS, Daulber: PC. Discontinuous anisotropic propagation. In: Rosen MR. Janse MJ, Wit AL, ods. Cardiac Electrophysiology: A Textbook. New York, NY: Futura Publishing Co; 1990: $517-534$

14. Dillon SM, Allessie MA. Ursell PC. Wit AL. Influence of anisotropic tissue structures on reentrant circuits in the picardial border zone of subacute canine infarces. Circ Res 1988; 65:182-206.

15. Azegami K, Satake S, Okishige K, Sasano T, Ohira H, Yamashita K. Monitoring the local dectrogram at the ablation site during radiofrequency application for common atrial fucter. Jpn Cind I 1998,62.559-564.

16. Shah DC, Harsaguerre M, Jais P. Takahashi $A$, Hocini M, Clementy J. High density mapping of activation through an incomplete isthmus ablation line. Cinculation $1999,99211-215$.

17. Jurevicius J. Fischmeister R. CAMP comparmentalization is responsible for a local activation of cardiac Cat2 chanch by beta-adrenergic agonists. Proc Narl Aad Sol $1996: 43: 295-299$

18. Lowenstein WR. Regulation of call-to-cell communication by phosphorylation. Biod Sin Symp $1985.50: 43-58$.

19. Matsuda JJ. Lee H, Shibata EF. Enhancement of rabbit cardiac sodium chanals by beta-adrenergic stimulation. Cim Res 1992;70:199-207.

20. Szekeres L. Papp JG. Effect of adrenergic activators and inhibitors on the electrical activity of the heart. In: Szekeres L, ed. Adrenergic activators and inhibitors. Berlin, Gemany: Springer Verlag; 1980,54(pt 1):597-634. 
21. Zuanetti G, Hoyt RH, Corr PB. $\beta$-adrenergic mediated influences on microscopic conduction in epicardial regions overlying infarcted myocardium. Cir Res $1990 ; 67: 284-302$.

22. Willems $\mathrm{S}$, Weiss $\mathrm{C}$, Hoffmam M, Meinercz $\mathrm{T}$. Simplified strategy for atrial flutter ablation using single electrode catheter for detection of functional block within the posterior isthmus. J Am Coll Cardiol 1998; (suppl 31):807-3. Abstract.

23. Nakagawa $H$, Jackman WM. Use of a three-dimensional, nonfluoroscopic mapping system for catheter ablation of typical atrial flutter. Pating Clin Electrophysiol $1998 ; 21: 1279-1286$.

24. Cauchemez B, Haissaguerre $M$, Fischer $B$, Thomas $O$, Clémenty $J$, Coumel $P$. Electrophysiological effects of catheter ablation of the inferior vena cava - tricuspid annulus isthmus in common atrial flutter. Circularion 1996;93:284-294.

25. Schwartzman D, Callans DJ, Gottlieb CD, Dillon S, Movsowitz C, Marchlinski FEE. Conduction block in the inferior vena caval - tricuspid valve isthmus: association with outcome of radiofrequency ablation of type I atrial flutter. I An Coll Cardiol $1996: 28: 1519-1531$ 
CHAPTER VII

\title{
Capture and fusion beats during atrial fibrillation and ventricular tachycardia
}

\author{
Ashish Nabar, MD; Luz-Maria Rodriguez, MD; Carl Timmermans, MD; \\ Klaus Kattenbeck, MD and Hein $\downarrow$ J. Wellens, MD. \\ Department of Cardiology, Academic Hospital Maastricht.
}




\section{ABSTRACT}

Two previously unreported observations were made during an electrophysiological study in 2 patients with idiopathic ventricular tachycardia (VT). Patient 1 had an idiopathic left VT while the patient 2 had an idiopathic right ventricular outflow tract VT. Firstly, initiation of idiopathic VT by atrial fibrillation (AF) was repeatedly observed. Secondly, fusion and capture beats were noticed during simultaneous VT and AF. An explanation is given why the latter phenomenon is rarely obserwed. 


\section{Case report}

\section{Patient 1}

A 50-year old man presented to the out-patient clinic with complaints of episodic palpitations and associated dizziness since 10 years. The 12 -lead ECG during sinus rhythm showed a horizontal QRS axis $\left(-30^{\circ}\right)$ and an incomplete right bundle branch block morphology. During arrhythmia, ECG revealed a regular broad QRS tachycardia (QRS width $190 \mathrm{~ms}$ ), cycle length of $260 \mathrm{~ms}$ with right bundle branch block morphology and a north-west QRS axis. Chest $\mathrm{x}$-ray, echocardiography, exercise testing, signal averaged ECG and coronary angiography were normal. A diagnosis of idiopathic ventricular tachycardia (V'T) originating from the left ventricle in the apico-septal region was made. ${ }^{1}$

An electrophysiological study was performed in a post-absorptive state after obtaining an informed consent. Sotalol was stopped 1 week before the study. The baseline $\mathbb{H V}$ interval measured $48 \mathrm{~ms}$. There was no ventriculoatrial conduction

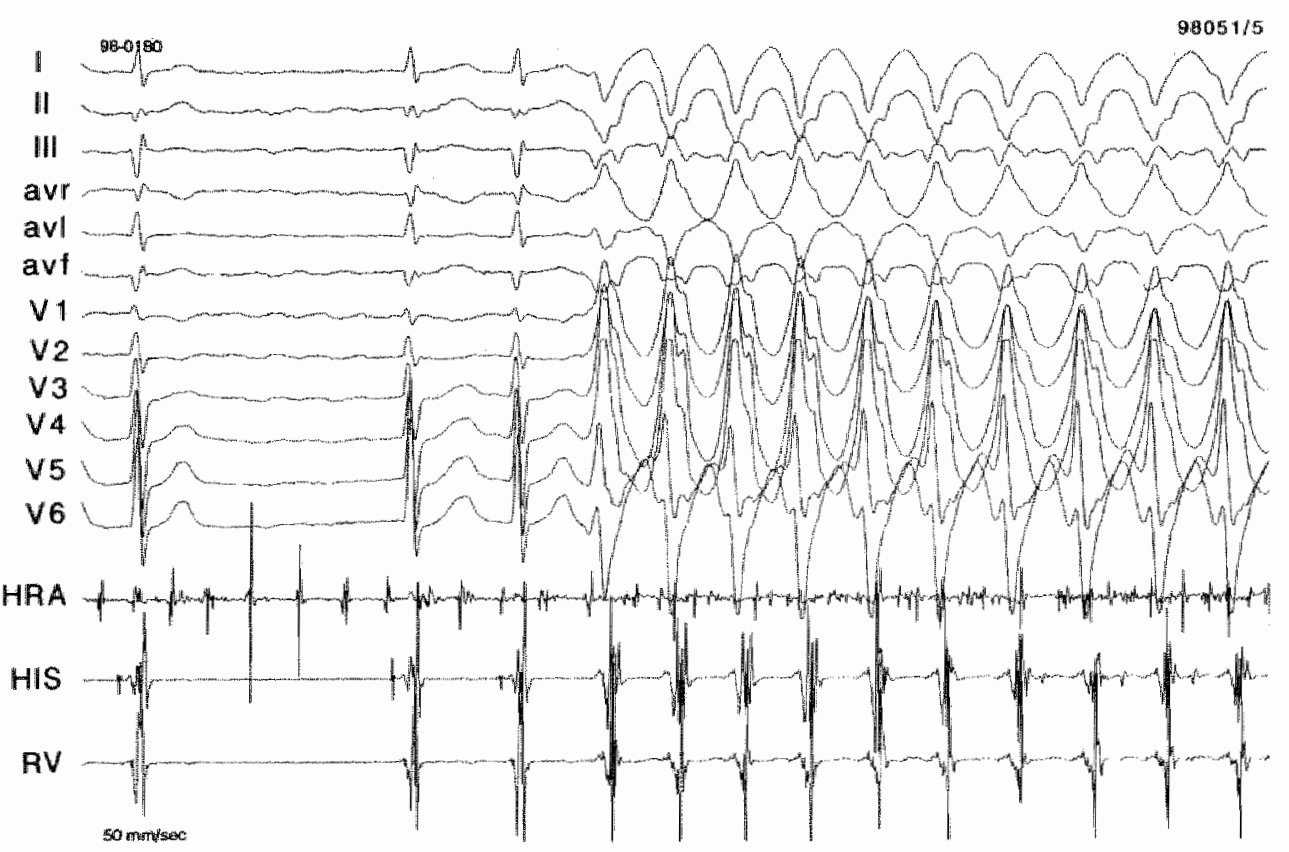

Figure 1. 12-leand ECG with endocardial recordings from Patient 1 during electrophysiologic study showing initiation of the ventricular tachycardia (VT) by atrial fibrillation (AF). HRA: High right atrium, HIS: His bundle, RV: Right ventricle. Note the long (1140 ms) - short $(450 \mathrm{~ms})$ $\mathrm{R} R$-cycle length sequence during $A F$ preceding the initiation of $V T$. 


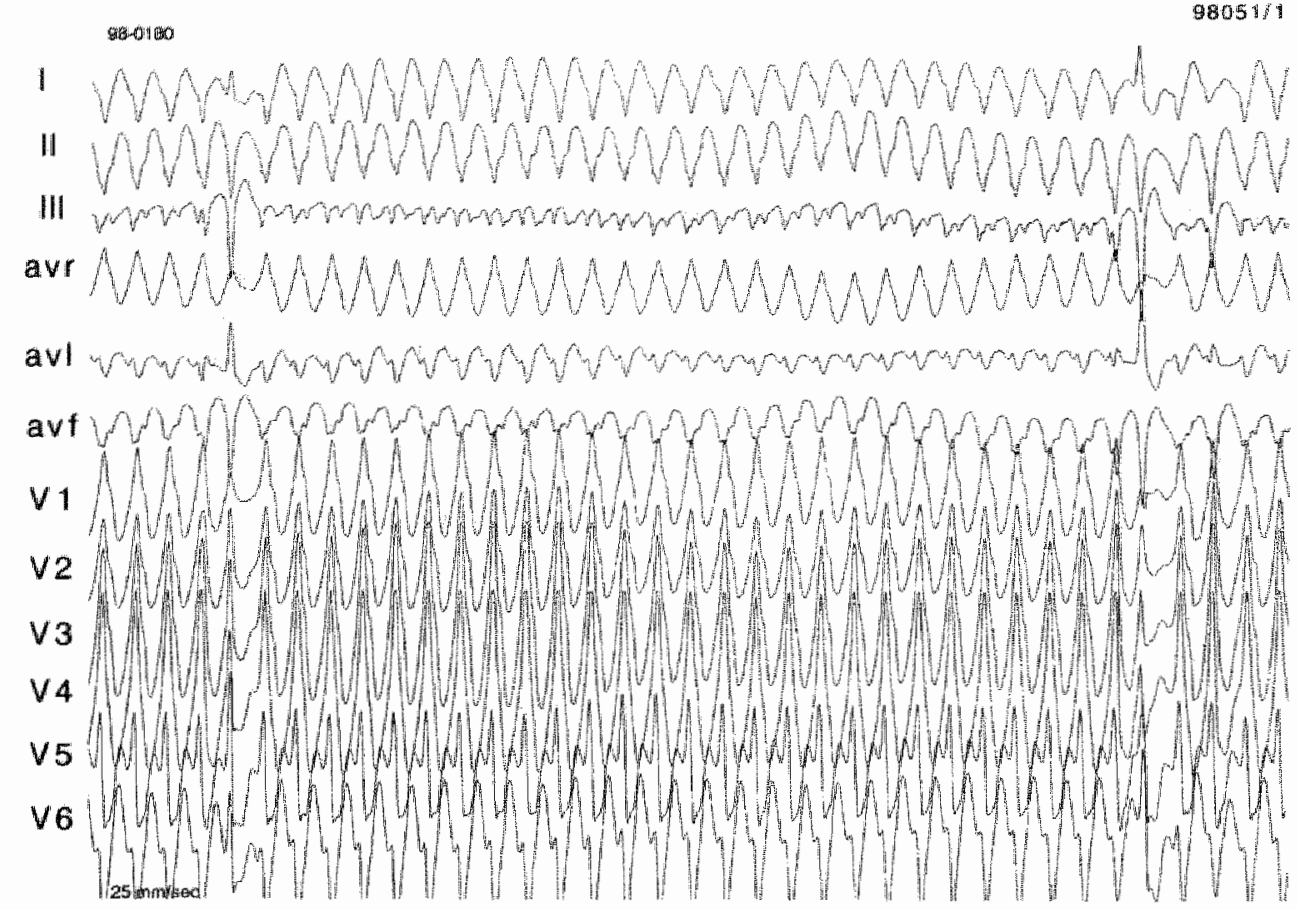

Figure 2. 12-lead ECG from Patient 1, recorded during simultaneous VT and AF. The fifth QRS beat, both from left and from right, represents a fusion beat with different degrees of fusion.

during ventricular pacing. Sustained monomorphic VT, identical to the clinical VT, was easily induced with a single ventricular extrastimulus delivered following ventricular pacing with a basic cycle length of $600 \mathrm{~ms}$. The VT could be teminated by overdrive ventricular pacing. Subsequently, sustained atriall fibrillation (AF) occurred while manipulating the catheter in right atrium and this initiated the same VT once again (Figure 1). Notably, VT initiation during AF was preceded by long followed by a short RR cycle (1140 and $450 \mathrm{~ms}$ respectively). Now, both the tachycardias (broad QRS-VT and AF) continued concomitantly. During simultaneous $V T$ and $A F$, a few narrow QRS beats varying in QRS width with an incomplete right bundle branch morphology were seen, suggesting a fusion beat (Figure 2). Both tachycardias continued incessantly. Intravenous procainamide $(500 \mathrm{mg}$ ) increased the VT cycle length to 280 ms but did not terminate the VT. The patient developed hemodynamic instability and was cardioverted.

Considering the difficulty in maintaining hemodynamic stability to permit VT mapping, the procedure was terminated. Radiofrequency ablation of the VT was planned at a later date. 


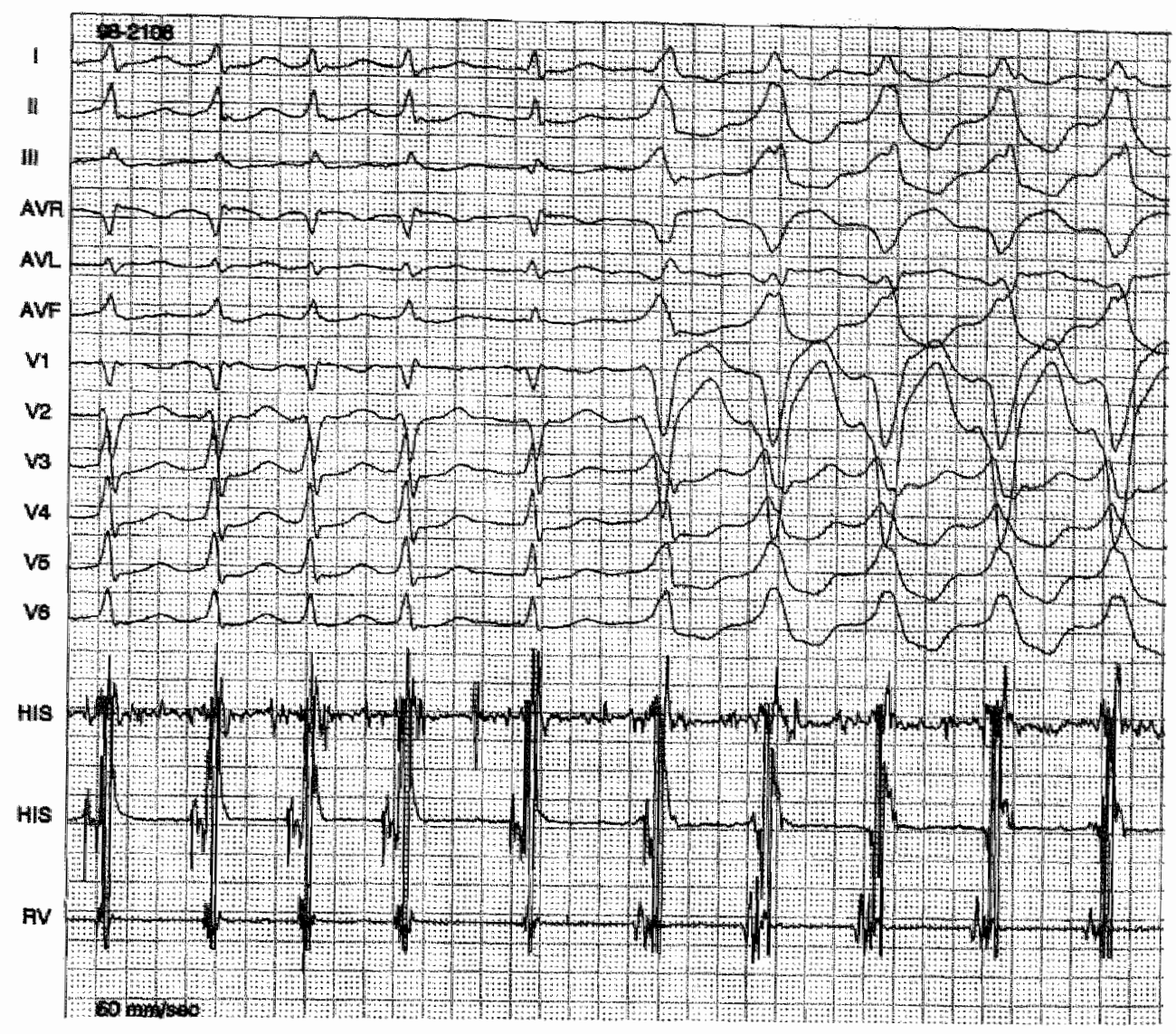

Figure 3. 12-lead ECG with endocardial recordings from Patient 2 during electrophysiologic study showing initation of VT by AF.

\section{Patient 2}

This 43-year old woman complained for 1 year of recurrent palpitations lasting few seconds to half an hour, 4 times associated with collapse. Physical examination was normal. The 12-lead ECG in sinus rhythm showed an intermediate QRS axis and incomplete right bundle branch block in lead V1. A regular, broad QRS tachycardia (QRS width $130 \mathrm{~ms}$ ), with a cycle length of 380 $\mathrm{ms}$, a left bundle branch block pattern and an intermediate axis was documented. Chest $x$-ray, echocardiography, exercise testing, Holter study and coronary angiography were nomal.

During electrophysiologic study, 3 VTs with a left bundle branch block morphology and cycle lengths of $360 \mathrm{~ms}$ (vertical axis, R-wave transition between lead V3 and V4), $280 \mathrm{~ms}$ (vertical axis, R-wave transition in lead V3) 

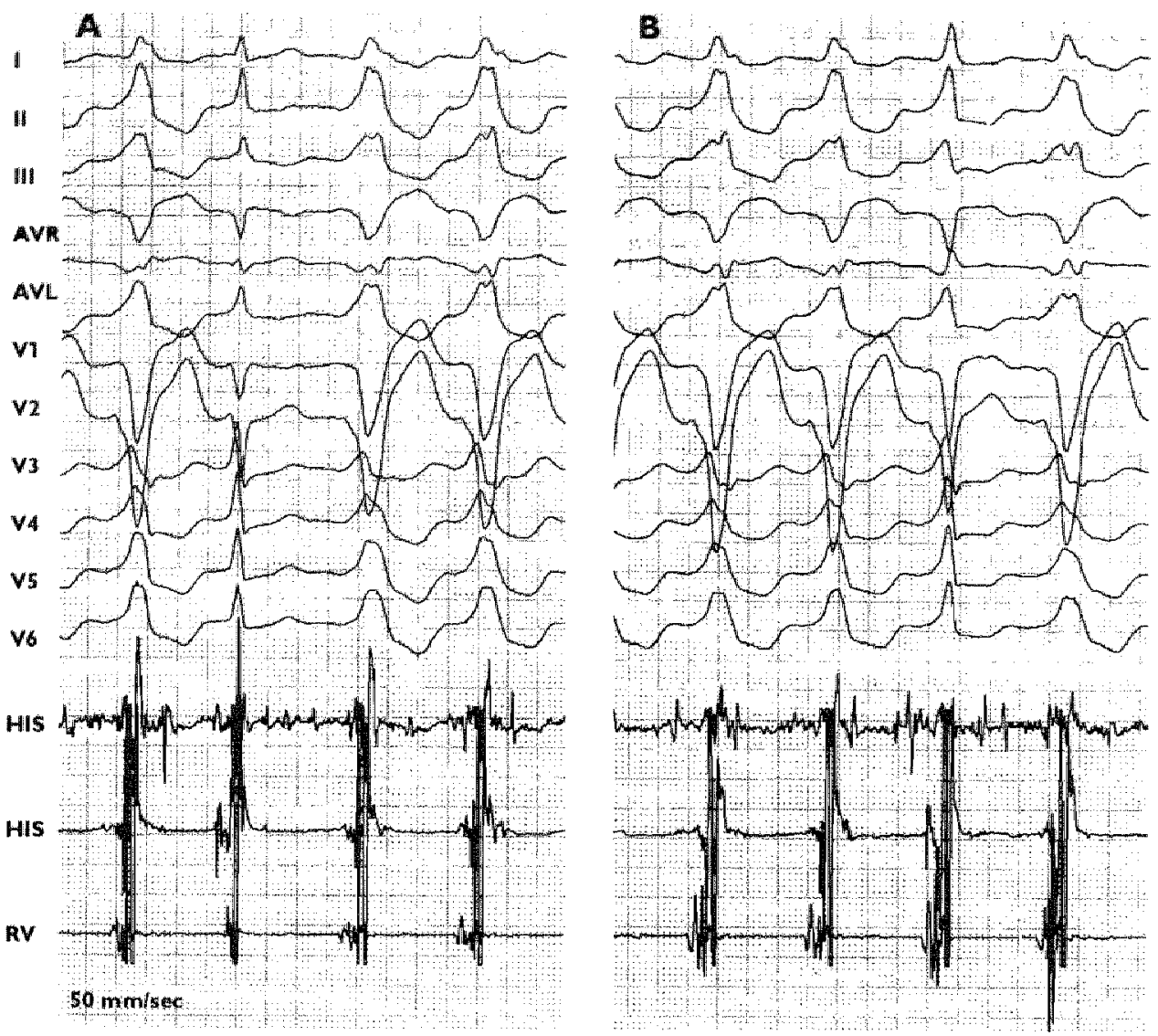

Figure 4. 12-lead ECG with endocardial recordings from Patient 2 during simultaneous VT and AF showing narow QRS beats. Panel A, shows a capture beat. Panel B, shows a tusion beat. Note the His bundle electrogram preceding both narrow QRS beats.

and $390 \mathrm{~ms}$ (axis $+60^{\circ}$ ) were induced by programmed ventricular stimulation. There was $2: 1$ and $1: 1$ ventriculoatrial conduction respectively during the first 2 VT morphologies. Sustained AF occurred spontaneously and repeatedly resulted in initiation of the $3^{\text {rd }}$ VT (Figure 3 ) after a longer RR-interval. In the presence of these simultaneously occurring tachycardias, narrow QRS beats resembling sinus QRS complexes, were intermittently observed. A His bundle electrogram, which during VT was within the QRS complex, was observed to precede the narrow QRS complex confirming a supraventricular capture of the ventricle during AF (Figure 4, Panel A). Additionally, fusion beats with a varying QRS width were noted (Figure 4, Panel B). 


\section{Discussion}

These cases illustrate two uncommon findings, initiation of VT during AF and the occurrence of fusion and capture beats following atrioventricular (AV) conduction during simultaneous AF and VT.

Firstly, the intiation of VT during AF. Wellens et al, reported that in $16 \%$ of patients with a clinically documented VT, the arrhythmia could be initiated during atrial pacing. ${ }^{2}$ Later, in patients with implantable defibrillator, sinus tachycardia, AF and atrial flutter have documented to be the initiating rhythm preceding appropriate shocks in ischemic VT. ${ }^{3}$ However, initiation of idiopathic VT by AF has not been reported. Atrial fibrillation provides rapid and irregular RR-intervals. Idiopathic left VT, as in patient 1 , is probably based on a reentrant mechanism. "The mechanism of idiopathic right ventricular outflow tract tachycardia (patient 2), triggered activity versus abnormal automaticity, is still unclear." A long-short RR-interval sequence during AF, as shown in figure 1 , could create a unidirectional block and start reentry. In the $2^{\text {nd }}$ patient, idiopathic right VT was induced by incremental atrial pacing and repeatedly by AF. In undiseased hearts with repetitive monomorphic VT, long preceding RR-intervals were found in $77 \%$ of cases. ${ }^{4}$ A repeated short-long pattern provided by irregular RR-intervals during AF could lead to a rapid escalation of pause dependent afterdepolarizations above a critical threshold initiating the VT. Lastly, overdrive excitation during AF leading to $\mathrm{Ca}^{+2}$ overloading and abnormal automaticity cannot be excluded. ${ }^{5}$

The second unusual observation, occurrence of supraventricular capture of the VT during AF. The ability of a supraventricular impulse to traverse the AV node, His bundle or bundle branches and to reach the ventricle depends upon 1) the antegrade AV nodal refractory period, 2) concealed antegrade conduction in the AV node, 3) the ventricular refractory period during VT, and 4) the ability during VT of retrograde invasion into the bundle branches, bundle of His and the AV node. As shown by Witkampf et al., in patients with AF ventricular pacing may prevent atrial impulses from reaching the ventricle. This suggest that during ventricular pacing in AF retrogracle penetration in the bundle branches, bundle of His or the AV node usually prevents supraventricular impulses from reaching the ventricle. In the $1^{\text {st }}$ patient no ventriculaatrial conduction was found during VT and ventricular pacing, not even at slow ventricular pacing rates. This may indicate inability to retrograde invasion into the conduction system. The fast VT rate with an RR-interval of 260 ms allowed only a small window of excitability in the ventricle by the captured beat. However, in the $2^{\text {mal }}$ patient, $1: 1$ and $2: 1$ ventriculoatrial conduction was present during ventricular pacing and VT indicating that antegradely conducted supraventricular impulses may capture the 
ventricle in patients having a capacity of ventriculoatrial conduction. Apparently not every beat of the VT penetrated retrogradely in the AV conduction system. Therefore, to be able to have capture and fusion beats during AF and VT several conditions have to be fulfilled: 1) no constant retrograde invasion into the $A V$ conduction system, 2) a sufficiently short antegrade AV nodal refractory period limiting "concealed" AV nodal conduction and 3) a ventricular rate during VT allowing the ventricle to be excitable when the supraventricular impulse arrives in the ventricle. This explains why the phenomenon of capture and fusion beats during AF and VT is seen so rarely.

\section{References}

1. Wellens HJJ, Rodriguez LM, Smeets JLRM. Ventricular tachycardia in structurally normal hearts. In Zipes DP, Jalife J, eds: Cardiac Electrophysiology. From Cell to Bedside. $2^{\text {nd }}$ edn. W. B.Saunders, Philadelphia, 1995:780-787.

2. Wellens HJJ, Bär FW, Farré J, Ross DL, Wiener I, Vanagt EJ. Initiation and termination of ventricular tachycardia by supraventricular stimuli. Incidence and electrophysiologic determinants as observed during programmed stimulation of the heart. Am J Cardiol 1980;46:576-582.

3. Marchlinski FE, Schwartzman D, Gottlieb CD, Gonzalez-Zuelgaray J, Callans DJ. Electrical events associated with arrhythmia initiation and stimulation techniques for arrhythmia prevention. In Zipes DP, Jalife J, eds: Cardiac Electrophysiology. From Cell to Bedside. $2^{\text {nd }}$ edn. W.B.Saunders, Plailadelphia, 1995, 863-877.

4. Zimmerman M, Maisonblanche P, Cauchemez B, Leclerq JF, Coumel P. Determinants of the spontaneous ectopic activity in repetitive monomorphic idiopathic ventricular tachycardia. J Am Coll Cardiol 1986;7:1219-1227.

5. Vassale M. Overdrive suppression and overdrive excitation. In Rosen MR, Janse MJ, Wit AL, eds: Cardiac Electrophysiology: A Textbook. Furura, Mount Kisco, NY, 1990; 175-190.

6. Witkampf FHM, De Jongste NJL, Lie KI, Meijler FL. Effect of right ventricular pacing on ventricular rhythm during atrial fibrillation. $J \mathrm{Am}$ Coll Cardiol $1988 ; 11: 539-545$. 


\section{Summary}

In recent years, radiofrequency (RF) ablation of atrial flutter (AFL) and atrial fibrillation (AF) has been continuously evolving. The challenges presented include; location of the optimal target tissue, amount of target tissue requiring destruction to effect a cure, methodology and the clinical subset likely to benefit maximally. In the nineties, advances in methods of RF ablation of AFL have lead to a significant improvement in the procedural results and long-term freedom from recurrences. On going work, both in the clinical and experimental setting, provides optimism regarding the use of catheter based therapy to treat AF at least palliatively, if not definitively in every patient with AF. The present thesis has discussed some of the advances as regards current status of catheter ablation of AFL and AF.

AF is the most common arrhythmia seen in clinical practice which is sustained by multiple reentrant wavelets based on anatomic and/or functional barriers. Because of its associated morbidity and mortality, this arthythmia is currently the focus of extensive dinical and experimental research. Multiple treatment options, both pharmacological and non-pharmacological, are being explored and as yet no single therapy is universally accepted. For the control of AF recurrences; new class III antiarthythmic drugs (AAD) such as ibutilide and azimilide, refinements in techniques and indications for RF ablation, use of the implantable atrial defibrillator, and single- or multi-site atrial pacing are the various approaches that are currently under investigation. As no single therapeutic intervention is ideal, a combination of modalities might achieve the most optimal effect.

AFL is a macro-reentrant arrhythmia most often contained within the right atrium (RA). The isthmus of atrial tissue bordered by the inferior vena cava and tricuspid annulus forms a critical zone of slow conduction and is crucial for mantenance of reentry. In contrast to RF ablation of AF, a majority of the recent studies report a procedural success $\geq 95 \%$ after ablation of type I AFL and an AFL recurrence rate of $<10 \%$. Therefore, RF ablation of type I AFL is curative and well-established, and can be recommended as the treatment of first choice.

When AADs are used intravenously or orally for AF, conversion vates between $35 \%$ and $80 \%$ are reported for restoration of sinus rhythm. However, the recurrence rate within first 6 months of achieving sinus rhythm is disappointingly high $(\approx 50-60 \%)$. Class IC agents (propafenone and flecainide) are recommended for patients with AF and no or minimal structural heart disease. Clinical and experimental studies in the human atrium have shown that in most instances $A F$ is 
an initiating arrhythmia for AFL. Although the exact incidence is not clear, the possibility of "transformation" of AF to AFL under the effects of AAD (both class I and III) is well-known. We define "class IC atrial flutter" as a new AFL developing in patients receiving class IC AADs for recurrent episodes of AF. The hypothesis of our study presented in Chapter II was, that successful RF ablation of the RA isthmus in patients with resistant AF who develop AFL while receiving class IC AAD therapy could favorably modify the "natural" course of AF. Fourteen patients ( $53.7 \pm 13.9$ years, 12 males) with daily recurrences of therapy resistant (median, 3 AADs) AF, paroxysmal $(n=8)$ or chronic persistent $(n=6)$, who developed class IC AFL (cycle length $=230 \pm 28 \mathrm{~ms}$ ) while on propafenone $(\mathrm{n}=$ 9) or flecainide ( $n=5$ ) therapy for a median duration of 3 months, underwent RF ablation of AFL by the anatomical approach. RF ablation was successful /AFL noninducible and bidirectional isthmus conduction (BIC) block] in 12 patients, partially successful [AFL non inducible but no BIC block] in 1 patient and failed [operated Ebstein's anomaly] in 1 patient. All, but 1 patient continued to take class IC AAD. At a mean follow-up of 4 months (range 2 to 13 months) following successfull RF ablation ( $\mathrm{n}=13$, including 1 partial success), 9 patients were symptom free and 2 patients have had a few (1 and 4 each), short-lasting AF recurrences. Thus 11 of $13(85 \%)$ patients improved clinically after RF ablation. The last two patients underwent successful repeat RF ablation for AFL recurrence but later had AF recurrences, albeit less frequent. RF ablation of the RA isthmus results in clinical improvement, at least short-term, in $85 \%$ of patients and provides an alternative management strategy for a subset of patients with therapy-resistant AF.

AFL and AF often coexist in the same patient. However, little attention is given to a previous history of AF in patients undergoing RF ablation for type I AFL. Further, it is not known whether elimination of AFL can modify the clinical behaviour of AF in patients who experience both these arrhythmias. Should we accept patients with documented AF for AFL ablation?

The goal of the study described in Chapter III was to test the hypothesis that the occurrence of AF, in at least some patients with coexisting type I AFL, is based on macro-reentry around the tricuspid valve orifice including the RA isthmus. This was done by evaluating AF recurrences following successful ablation of AFL. Eighty-two consecutive patients with type I AFL, with or without concomitant AF, underwent RF ablation of the RA isthmus by an anatomical approach. The results were analyzed in 4 groups of patients: group 1 (only AFL; 29 patients), group 2 (AFL > AF; 22 parients), group 3 (AF > AFL; 15 patients) and group 4 (class IC AFL; 16 patients). In all groups, RF ablation of type J AFL was performed with a high $(\geq 93 \%)$ procedural success rate. In group 1, only 2 $(8 \%)$ patients had AF after $(18 \pm 14$ months) AFL ablation. These figures were 
$38 \%$ ( $20 \pm 14$ months) and $86 \%$ (13 \pm 8 months) in groups 2 and 3, respectively. Group 4 patients ( $4 \pm 2$ months) had a $73 \%$ freedom of AF recurrences in continuation with a class IC agent. We conclude that the low incidence of new AF during long-term follow-up after RF ablation of type I AFL makes it unlikely that RF lesions promote the development of AF. The impact of isthmus ablation on AF recurrences differs according to the clinically predominant atrial arrhythmia and suggests a possible role of the RA isthmus in the occurrence of AF in some patients. Ablation of class IC AFL in patients with therapy-resistant AF is a novel approach to management of this patient subset. Careful classification of AF patients plays a role in the selection of the site of ablation therapy.

The concept of "hybrid" therapy is that in a given patient with AF, a combination of therapeutic modalities may be useful by achieving a synergistic effect. "Organized" pattern of AF may facilitate the effects of non-pharmacological therapies, such as ablation, defibrillation and pacing. The usefulness of the "hybrid" approach (presented in Chapter II), for patients with AF who develop AFL during AAD (class IC) therapy will depend upon the improvement with regard to control of AF recurrences at long-term. A standard 12-lead ECG remains the comerstone for clinical recognition of AFL. The aim of the study included as Chapter IV was 1) to describe the ECG and electrophysiologic characteristics of the so called class IC AFL and 2) to report long-term success following $R A$ isthmus ablation, in relation to their $E C G$ pattern during AFL. The 12-lead ECG findings during electrophysiological study, acute results of RA isthmus ablation, and long-term outcome as to AF recurrences were examined in 24 consecutive AF patients (54 \pm 12 years, 19 males) who were diagnosed as developing AFL while taking propafenone $(n=12)$ or flecainide $(n=12)$. On retrospective analysis, ECG was considered suggestive of typical AFL in 13 patients (54\%). The ECG was classified as atypical AFL $(n=8)$ or coarse AF $(n=$ 3) in the remaining patients. On electrophysiological study, the RA isthmus conduction time was slower in lateromedial than in mediolateral direction (104 1 32 ms versus $75 \pm 34 \mathrm{~ms}, \mathrm{P}=0.023$ ). During the study, a counterclockwise (CCW) AFL was documented in 7 out of 7 and 4 out of 5 patients having typical and atypical AFL respectively. Acute success of ablation was similar in patients with typical (92\%) and atypical (100\%) AFL. Ar long-term follow-up $(13 \pm 6$; range, $6-26$ months), continution of AAD therapy resulted in better control of AF recurrences, in patients with typical (11 out of 13 ) than atypical (4 out of 8 ) AFL. Coarse AF $(n=3)$ persisted despite ablating the RA isthnus. At follow-up, the latter 3 patients continued to have frequent recurrences of $A F$. This study showed that, in patients with class IC AFL, electrocardiographically both typical and atypical AFL morphologies are seen. The AFL circuit was always located in $\mathrm{RA}$ and the isthmus was crucial for maintaining reentry. The best long-term 
control of AF using the "hybrid" approach was obtained in patients with an AFL ECG pattem of typical AFL. Patients developing coarse AF are no candidates for this strategy.

Unfortunately, transformation to class IC AFL cannot be predicted. Furthermore, the exact incidence of $A F L$ in patients with $A F$ receiving $I C A A D$ therapy and the AF subset most likely to develop this transformation needs to be defined. More data are needed regarding dose and duration of class IC therapy resulting in class IC AFL, and the risk of proarthythmia (1:1 atrioventricular conduction during AFL) when given to ambulatory patients. Until a larger, prospective and controlled long-tem experience regarding the efficacy and safety is available; this strategy, although beneficial to suppress the frequent and unpleasant symptoms of AF, cannot be regarded as established and widely applicable to all patients with $\mathrm{AF}$.

Clinical experience using a long tip electrode for $\mathbb{R F}$ catheter ablation of type I AFL is largely observational. Therefore, in Chapter V we compared a new RF catheter design with an 8-mm split-tip electrode having integrated thermocouples [Cerablate ${ }^{\circledR}$ plus Flutter, Dr Osypka GmbH]), (group I) with a 4-mm tip electrode (group II) in a prospective randomized manner. Thirty consecutive patients were randomized to group I or II. For ablation of the RA isthmus 90 second RF pulses were used at sequential sites with a preset temperature of $55^{\circ} \mathrm{C}$. All patients in group I and all but 1 patient in group II underwent successful ablation. A significantly lesser number of RF pulses and a shorter mean fluoroscopy time was found using an $8-\mathrm{mm}$ split-tip electrode [RF pulses $12 \pm$ 3.5 in group I versus $27 \pm 9$ in group II $(P<0.0001)$, fluoroscopy time $23 \pm 13$ in group I versus $45 \pm 28 \mathrm{~min}$ in group II $(P=0.01)$ ]. With comparable mean follow-up times $[4.3 \pm 2.8$ in group I versus $4.8 \pm 2$ months in group II], only $\mathbb{1}$ patient in group II had an AFL recurrence. Our conclusions were, that ablation of type I AFL can be performed using an $8-\mathrm{mm}$ split-tip RF catheter. Requirement of less RF pulses and thoroscopy time suggest superiority of an $8-\mathrm{mm}$ split-tip electrode over a 4-mm tip electrode.

After RF ablation of AFL the demonstration of BIC block is considered the hallmark of a successful procedure. The purpose of our study presented in Chapter VI was to test the persistence of BIC block after isoproterenol administration and to evaluate the importance of this finding with regard to AFL recurrences. RF ablation of AFL was performed in 44 consecutive patients with type I AFL by a linear ablation of the posterior isthmus $(n=29$ parients), septal isthmus ( $n=4$ patients), or both RA isthmi ( $n=11$ patients). The procedural end point was complete BIC block and noninducibility of AFL. In case of noninducibility and apparent BIC block, the pacing protocol was repeated under isoproterenol infusion (1 to $3 \mu \mathrm{g} / \mathrm{min}$ ). Reversal of apparent BIC block occurred in 7 (15.9\%) 
of 44 patients. Six patients had bidirectional and 1 had unidirectional resumption of isthmus conduction. CCW-AFL could be reinduced in 4 of these patients. Two to 24 (median, 4) additional RF applications were required to achieve a permanent BIC block. At a mean follow-up of $7.3 \pm 7.6$ months (range, 2 to 31 months), 2 (4.5\%) of 44 patients had. AFL recurrences. Partial linear RF ablation could possibly aggravate the preexisting nonuniform anisotropic conduction in the RA isthmus, resulting in profound conduction slowing and apparent BIC block. Isoproterenol can unmask apparent BIC block, thus providing an opportunity to assess the possibility of reversal of BIC block and completeness of isthmus ablation during the same procedure. The low incidence $(4.5 \%)$ of AFL recurrences at follow-up suggests that noninducibility and BIC block under isoproterenol infusion may be a better endpoint for successful AFL ablation.

Two interesting observations made in 2 patients with idiopathic left and right ventricular outflow tract ventricular tachycardias (VT), during the presence of simultaneous AF and VT are the subject of Chapter VII. AF repeatedly initiated the VT. The possible role of irregular RR-intervals, with reference to the known mechanism of idiopathic V'T viz reentry (left VT) and triggered activity versus abnormal automaticity (right ventricular outflow tract VT), are discussed. Also, capture and fusion beats were observed during the dual tachycardias. The conditions that have to be fulfilled by the AV conduction system to permit a supraventricular capture of the ventricle when both tachycardias are incessantly present are discussed. 



\section{Samenvatting}

De laatste jaren hebben nieuwe onwikkelingen plats gevonden op het gebied van radiofrequentie catheter ablatie (RF-ablatie) van boezemflutter en boezem-fibrilleren. Belangrijke vragen hierbij zijn onder meer: war is de plats in het atrium waar RF-ablatie een optimaal resultat heeft; hoeveel atrial weefsel moet geableerd worden om de ritmestoornis onder controle te brengen; wat is de beste methodologie en welke categorie patienten heeft er het meeste bat bij? In de negentiger jaren hebben nieuwe methodes voor RF-ablatie van boezemfibrilleren en boezemflutter geleid tot een belangrijke verbetering van het directe succespercentage en de resultaten op langere termijn. In dit proefschrift worden een antal van deze nieuwe ontwikkelingen besproken.

Boezemfibrilleren is de meest frequent voorkomende ritmestoomis bij de mens en is gebaseerd op multipele re-entry golven op basis van anatomische en/of functionele barrières in de boezem. Vanwege de morbiditeit zoals pompfalen en thrombo-embolieèn en ook de toename in mortaliteit van deze ritmestoomis vindt veel klinisch en experimenteel onderzoek plaats. Zo zijn zowel farmacologische als niet-farmacologische behandelingsmogelijkheden onderzocht. Het is daarbij duidelijk geworden dat er geen uniform succesvolle behandeling bestaat. Voor de behandeling van recidiverend boezemfibrilleren zijn momenteel de volgende nieuwe behandelwijzen in onderzoek: farmacologische therapieën met nieuwe klasse III anti-aritmica zoals ibutilide en azimilide; en niet-farmacologische therapieën zoals RF-ablatie van paroxysmal en chronisch boezemfibrilleren, implantatie van een boezendefibrillacor en atriale stimulatie op een of meerdere plaatsen. Aangezien deze therapeutische interventies afzonderlijk niet altijd tot een succesvolle behandeling leiden, zal het meest optimale effect vaak alleen met cen combinatie van therapieen berakt kunnen worden.

De boezemflutter is een ritmestoomis die het gevolg is van een macroreentry circuit dat meestal in het rechter atrium gelokaliseerd is. Een essentieel onderdeel van het circuit is de isthmus van atrial weefsel dat begrensd wordt door de vena cava inferior en de tricuspidaal annulus. Dit is een zone met trage geleiding en speelt een cruciale rol bij het in stand houden van reentry. RF ablatie van deze zone geefi bij boezemflutter een direct succes $\geq 95 \%$ met een recidiefpercentage $<10 \%$. Derhalve is de R. F-ablatie van de boezemfluter een curatieve therapie en kan dan ook anbevolen worden als behandelling van eerste keuze bij patiënten met recidiverende anvallen van boezemflutter. Bij intraveneuze of orale toediening van anti-arimica bij boezemfibrilleren wordt bij $35 \%$ tot $80 \%$ van de pariènten therstel van sinusritme wargenomen. Het recidiefpercentage van 
boezemfibrilleren in de 6 maanden daama ligt echter hoog $(50-60 \%)$. Klasse 1 anti-arimica (propafenon en flecainide) worden aanbevolen voor patienten met boezemfibrilleren zonder of met minimale structurele hartafwijkingen. Bij klinisch en experimenteel onderzoek bij de mens is angetoond dat de boezemflutter in de meeste gevallen door boezemfibrilleren geinirieerd wordt. Hoewel de exacte incidentie ervan niet duidelijk is, is het een bekend feit dat boezemfibrilleren onder inwloed van anti-arrhythmica (zowel klasse I als III) tot boezemflutter kan "transformeren". Wij spreken van "klasse IC boezemflutter" als de boezemflutter optreedt bij patiënten die met klasse IC anti-arrhythmica behandeld worden voor recidiverende episodes van boezemfibrilleren. De in Hoofdstuk II weergegeven hypothese luidde dan ook dat een geslaagde RF-ablatie van de RA-isthmus het "natuurlijk" verloop van boezemfibrilleren in gunstige zin kan modificeren bij patienten met boezemfibrilleren bij wie zich boezemflutter ontwikkelt tijdens een behandeling met klasse IC antiarrhythmica. Veertien patiènten $(53,7 \pm 13,9$ jaar, 12 mannen) met dagelijks aanvallen van therapie-resistent boezemfibrilleren, paroxysmaal $(n=8)$ of chronisch $(n=6)$, bij wie zich een klasse IC boezemflutter (cyclus lengte $=230 \pm 28 \mathrm{~ms}$ ) ontwikkelde tijdens een behandeling met propafenon $(n=9)$ of flecainide $(n=5)$, ondergingen RF-ablatie van hun boezemflutter. RF-ablatie had bij 12 patiënten succes 〔boezemflutter niet-induceerbaar en bidirectioneel isthmus geleidingsblok]. Bij 1 patient was er gedeeltelijk [boezemflutter niet-induceerbar maar geen bidirectioneel isthmus geleidingsblok] en bij 1 patiënt geen succes [een patiënt met een geopereerde anomalie van Ebstein]. Bij op één na alle patiënten werd de toediening van klasse IC anti-arrhythmica voortgezet. Bij een gemiddelde follow-up van 4 maanden (2 tot 13 maanden) na een succesvolle RF-ablatie ( $\mathrm{n}=13,1$ gedectrelijk succes inbegrepen) waren 9 patiënten vrij van hun ritmestoornis en hadden 2 patiënten enkele kortdurende recidieven van boezemfibrilleren. Van de 13 patiënten waren er dus 11 (85\%) klinisch verbeterd na RF-ablatie. De twee patienten met kortdurende recidieven ondergingen met succes een tweede RF-ablatie van de rechter atrium-isthmus. Dus bij $85 \%$ van dit soort patienten was er sprake van klinische verbetering, in ieder geval op de korte termijn, en is er dus een meuwe behandelingsmogelijkheid voor een bepaalde categorie patienten met therapieresistent boezenfibrilleren.

Boezemflutter en boezemfibrilleren komen vaak samen woor bij één patiënt. Er wordt echter weinig aandacht geschonken an het optreden van boezemfibrilleren bij patiënten die RF-ablatic ondergaan voor een boezemflutter. Voorts is het niet bekend of ablatie van de boezemflutter een modificerend effect heeft op de hoevelheid anvallen van boezemfibrilleren bij patiënten met een combinatie van deze ritmestoomissen. De vraag is dus of wij patiënten voor boezemflutterablatie moeten accepteren bij wie ook boezemfibrilleren is geregistreerd. 
In Hoofdstuk III werd de hypothese getest dat boezemfibrilleren zow kumnen optreden bij patiẻnten met boezemflutter, op basis van macro-reentry rond de tricuspidaal annulus met inbegrip van de rechter atrium-isthmus. Deze hypothese werd getest door het optreden van recidieven van boezemfibrilleren na een met succes uitgevoerde boezemflutter-ablatie te evalueren. Tweeëntachtig opeenvolgende patiènten met boezemflutter, al of niet met gedocumenteerde aanvallen van boezemfibrilleren, ondergingen RF-ablatie van de rechter boezem-isthmus. De resultaten werden in 4 groepen van patiënten geanalyseerd: groep 1 (uitsluitend documentatie van boezemflutter; 29 patiënten), groep 2 (meer aanvallen van boezemflutter dan boezemfibrilleren: 22 patiënten), groep 3 (meer aanvallen van boezemfibrilleren dan boezemflutter; 15 patienten) en groep 4 (klasse IC boezemflutter; 16 patiënten). In alle groepen had RF-ablatie van de boezemflutter een hoog (293\%) succespercentage. In groep 1 ontstond bij slechts 2 patiënten $(8 \%)$ boezemfibrilleren na $18 \pm 14$ maanden. In beide gevallen na hartchirurgie. In de groepen 2 en 3, bedroegen deze cijfers

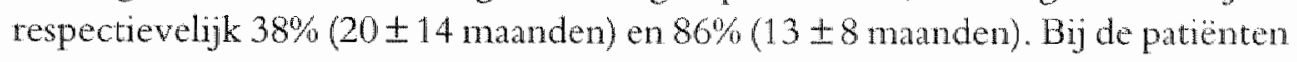
van groep 4 bleef $73 \%$ ( $4 \pm 2$ maanden) vrij van boezemfibrilleren-recidieven bij verdere toediening van een klasse IC anti-aritmicum. De conclusie is dat, gezien de lage incidentie van nieuwe boezemfibrilleer-episoden tijdens een lange-termijn follow-up na RF-ablatie van patienten met alleen boezemflutter, het onwaarschijnlijk is dat RF-laesies het ontstaan van boezemfibrilleren bevorderen. Het effect van isthmus-ablatie ten aanzien van het recidiveren van boezemfibrileren is afhankelijk of het boezemfibrilleren of de boezemflutter de nneest voorkomende ritme-stoomis is. Ablatie van de klasse IC boezemflutter bij patienten met therapie-resistent boezemfibrilleren is een nieuwe benadering in de behandeling van deze patienten. Een zorgvuldige classificatie van patiènten met boezemfibrilleren speelt dus een rol bij de beslissing een isthmus ablatie al of niet uit te voeren.

Het concept van een "hybride" therapie berust op de gedachte dat een combinatie van farmacologische en niet-famacologische therapeutische matregelen bij de patiënt met boezemfibrilleren bruikbar kan zijn. Een voorbeeld van de "hybride" benadering (zie ook Hoofdstuk II) is het uitvoeren van een isthmus ablatie bij patiënten met boezemfibrilleren bij wie zich tijdens een therapie met klasse IC anti-arrhythmica een boezemflutter ontwikkelt. De in Hoofdstuk IV beschreven studieopzet was om uit te zoeken of bepalde ECG bevindingen tijdens de klasse IC boezemflutter van voorspellende warde waren ten aanzien van het lange-termijn effect van rechter boezem-isthmus-ablatie. Daamaast werden ook de electrofysiologische karakteristieken van de klasse $1 \mathrm{C}$ boezemflutter bestudeerd. Dit onderzoek werd verricht bij 24 opeenvolgende patienten (54 \pm 12 jar, 19 mannen) met boezemfibrilleren die boezemflutter ontwikkelden 
tijdens een behandeling met propafenon $(n=12)$ en flecainide $(n=12)$. Bij retrospectieve ECG analyse werd bij 13 patienten een klassieke boezemflutter gevonden. Bij de overige patienten werd het ECG als atypische boezemflutter (n $=8)$ of grofslagig boezemfibrilleren $(\mathrm{n}=3$ ) geclassificeerd. Bij elektrofysiologisch onderzoek bleek de geleidingstijd van de rechter boezem-isthmus in lateromediale richting langer te zijn dan in mediolaterale richting (104 $\pm 32 \mathrm{~ms}$ versus $75 \pm 34 \mathrm{~ms}, P=0,023$ ). Tijdens de studie werd er een 'counterclockwise' boezemflutter gevonden bij 7 van de 7 en 4 van de 5 patienten met respectievelijk een typische en een atypische boezemflutter. Het onmiddellijke succes was bij patienten met een typische $(92 \%)$ en atypische (100\%) boezemflutter ongeveer geljjk. Bij lange-termijn follow-up (13 16 ; uitersten: 6 - 26 maanden) bleek dat continueren van de anti-aritmische therapie een gunstiger effect op het optreden van boezemfibrilleren recidieven had bij patiënten met een typische (11 van de 13) boezemflutter dan bij patiënten met een atypische (4 van de 8) boezemflutter. Grofslagig boezemfibrilleren bleef bestaan $(n=3)$ ondanks ablatie van de rechter boezen-isthmus. Bij follow-up bleek dat bij deze hatste 3 patiënten het boezemfibrilleren frequent recidiveerde. Deze studie heeft dus aangetoond dat er bij klasse IC boezemflutter elektrocardiografisch zowel typische als atypische flutter morfologieën gezien worden. Het flutter circuit was altijd in het RA gelokaliseerd en de isthmus speelde een cruciale rol bij het in stand houden van de reentry. Met de "hybride" benadering werd boezemfibrilleren op lange termijn het beste onder controle gehouden bij patienten met een ECG-patroon van een typische boezemflutter. Patiènten bij wie grofslagig boezemfibrileren ontstaat na klasse IC antiarrhythmica komen niet in aanmerking voor rechter boezemisthmus ablatie.

Transformatie van boezemfibrilleren nar klasse IC boezemflutter is helaas niet te voorspellen. Ook is de exacte incidentie hiervan niet bekend. Meer gegevens zujn nodig over dosering en duur van de klasse IC-behandeling die een dergelijke transformatie tot gevolg hebben. Ook zal bekeken moeten worden of en hoe vaak een klasse $1 \mathrm{C}$ behandeling bij patiënten met boezemfibrilleren leidt tot pro-arrhythmieën zoals 1 op 1 atrioventriculaire geleiding.

De klinische ervaring met een lange-tip elektrode voor RF-ablatie van boezemflutter is beperkt. In Hoofdstuk $\mathbf{V}$ wordt een prospectief, gerandomiseerd onderzoek beschreven wan een nieuw ontworpen RF-catheter met een 8 $\mathrm{mm}$ split-tip-elektrode met geintegreerde themokoppels [Cerablate plus Flutter, Dr Osypka GmbHl (groep I) in vergelijking met een $4 \mathrm{~mm}$ tip-elektrode (groep II). Er werden 30 patiënten onderzocht en ingedeeld in groep II of II. Voor ablatie van de rechter boezem-isthmus werden RF-pulsen van 90 seconden gebruikt met een vooraf ingestelde temperatuur van $55^{\circ} \mathrm{C}$. Bij alle patiënten uit groep I en opéén na alle patiènten uit groep II werd de ablatie met succes uitgevoerd. Bij 
gebruik van een $8 \mathrm{~mm}$ tip-elektrode werden een significant lager aantal RF-pulsen gebruikt en een kortere gemiddelde fluoroscopietijd gevonden $[R \mathbb{F}$ pulsen $12 \pm 3,5$ in groep I versus $27 \pm 9$ in groep II $(P<0,0001)$, fluoroscopietijd $23 \pm 13 \mathrm{~min}$. in groep I versus $45 \pm 28 \mathrm{~min}$. in groep $I(P=0,01)]$. Bij een vergelijkbare gemiddelde follow-up-tijd $[4,3 \pm 2,8$ maanden in groep I versus $4,8 \pm 2$ maanden in groep II] trad bij slechts éen patiënt (uit groep II) een recidief van boezemflutter op. Onze conclusie luidt dat gezien het feit dat er minder RF-pulsen en minder fluoroscopietijd nodig zijn, een $8 \mathrm{~mm}$ split-tip elektrode effectiever is dan een 4 mm elektrode.

Als er na RF-ablatie van boezemflutter een bidirectioneel isthmus-blok aangetoond wordt, dan wordt dat beschouwd als bewijs van een met succes uitgevoerde procedure. De in Hoofdstuk VI beschreven studie had als doel om na te gaan of blijvende afwezigheid van dat blok na toediening van isoproterenol van belang was om het lange termijn succes te voorspellen. Er werd bij 44 opeenvolgende patiënten met een boezemflutter een RF-ablatie uitgevoerd door middel van een lineaire ablatie van de posterior isthmus $(n=29$ patiënten), de septale isthmus $(n=4$ patiënten), of beide rechter boezem-isthmi $(n=11$ patiënten). Het eindpunt van de procedure was een volledig bidirectioneel isthmus blok en de onmogelijkheid om boezenflutter te induceren. Bij niet-induceerbaarheid en een kennelijk bidirectioneel isthmus-blok werd het stimulatieprotocol herhaald maar nu onder een isoproterenol-infusie (1 tot 3 $\mu g / m i n)$. Bij $7(15,9 \%)$ van de 44 patiënten verdween het bidirectioneel isthmus-blok. Bij 6 patiënten kwam bidirectionele en bij 1 patient unidirectionele isthmusgeleiding terug. Bij 4 van deze patienten kon toen opnieuw een boezemflutter geinduceerd worden. Er waren 2 tot 24 (mediaan: 4) extra RF-applicaties nodig om een blijvend bidirectioneel isthmus-biok te berciken. Bij een gemiddelde follow-up van $7,3 \pm 7,6$ manden (uitersten: 2 en 31 maanden) trad er bij $2(4,5 \%)$ van de 44 patiénten een recidief van de boezemflutter op. Partiele lineare RF-ablatie heeft de preexistente non-unifome anisotrope geleiding in de rechter atrium-isthmus mogelijk verergerd, hetgeen resulteerde in een emstige geleidingsvertraging en een ogenschijnlijk bidirectioneel isthmus-blok. Met isoproterenol kan dit ontmaskerd worden, waama tijdens dezelfde procedure door herhaalde RF ablatie een volledig bidirectioneel isthmus blok kan worden bereikt. De lage incidentie $(4,5 \%)$ van boezenflutter recidieven bij de follow-up duidt erop dat niet-induceerbarheid en een bidirectioneel isthmus-blok onder isoproterenol-infusie een goed eindpunt is voor een succesvolle boezemflutter-ablatie.

Twee interessante waamemingen bij 2 patiënten met respectievelijk een idiopathische linker en een idiopathische rechter kamertachycardie vormen de inhoud van Hoofdstuk VII. Bij beide patiënten was er sprake van gelijktijdig 
optreden van de kamertachycardie en boezemfibrilleren. De kamertachycardie werd herhaaldelijk door het boezemfibrilleren geinitieerd. Het mechanisme hiervan, met name de rol van het wisselende $\mathrm{R}-\mathrm{R}$ interval tijdens boezemfibritleren, wordt besproken. Tijdens het gelijktijdig bestaan van de twee tachycardieen werden capture en fusion beats waargenomen. Er wordt aangegeven aan welke voorwaarden het $\mathrm{AV}$-geleidingssysteem moet voldoen wil supraventriculaire capture van de ventrikel mogelijk zijn tijdens deze situatie. 


\section{सारांरा}

नबज़ (हद्य की धड़कन) तेज़ होने के कई कारण हैं । इन कारणोंमें शामिल है, एट्रियल फित्रिलेशन (atrial fibrillation, AF) और एट्रियल फ्लटर (atrial flutter, AFL) । पिछले कुछ सालोक्मे, इन दोनो हीं कारणोकी रेडिओफ़्रिक्वेन्सी अब्लेशन (radiofrequency ablation, RFA) चिकित्सा पद्धती में निरंतर प्राता हो रही है। फिर भी, इस उपचार पद्धती से संबंधित कई प्रश्न अभी भी अनुत्तरीत हैं, जैसे कि: हद्य का वह कौन सा भाग इस चिकित्सा पद्धती केलिए सही लक्ष्य होगा, इस लक्ष्य को अब्लेट करने की कौनसी विधी सवोत्त्तम मानी जा सकती है, तथा AFL और $\mathrm{AF}$ के किन मरिजोंको इस चिकित्सा पद्धती का सबसे अधिक लाभ होगा? इस विषय को लेकर आयुर्विजान में जो प्रगती हो रही है, उससे ऐसा प्रतीन होता है कि, आने वाले वर्षोमें RFA चिकित्सा पद्धतो से $A F$ के कुछ मरिजोंको काफ़ी हुद तक लाभ पहुँच सकता है। यही प्रस्तुत प्रबंध का विषय है।

$\mathrm{AF}$, यह नब्ज़ के तेज़ होने का एक आम कारण भी है। ऐसा माना जाता है कि, हृद्यय में इसका उत्पन्न होना, एट्रिया (atria) के भीतर, एक ही समय, अनेक तरंगोंके घुमते रहने पर (random reentry of multiple wavelets) निर्भर है। AF के कारण, शरीरमें अन्य दुष्परिणाम संभव हैं। इसलिए, इन दिनों, इस विषय को लेकर काफ़ी शोधकार्य हो रहा है। नयी उपचार पद्धतियों में संमिलित है: नयी वर्ग 3 अन्टी ऑरिद्मिक् औषधियाँ (antiarrhythmic drugs, AAD) जैसे कि आयब्युटिलाइड (ibutilide) और ऑझिमिलाइड (azimilide), RFA चिकित्सा के नये तरीके, हृद्य में लगाया जाने वाला एट्रियल डिफिब्रिलेटर उपकरण (implantable atrial defibrillator) तथा एक-अथवा अनेक-स्थानों से एट्रियल पेसिंग (single- or multi-site atrial pacing)। क्योंकि, इनमेंसे कोईभी एक उपचार पद्धती, AF के सभी तरह के मरिज़ोंकेलिए योग्य नही है, यह संभव है कि, एकसे अधिक पद्धतियोका प्रयोग करना उचित होगा।

AFL दाहिने एट्रियम (right atrium) में एक बडे तरंग (macro-reentrant wave) के घुमके रहने से उत्पन्न होता है। दाहिने एट्रियम के इस्थमस् (isthmus) की सीमाएँ, इन्फीरियर विना कावा (inferior vena cava) एवं ट्रायकस्पिड अन्युलस (tricuspid annulus) व्दारा बनती है। इन्हीं सीमाओं के मध्य, AFL के इस बड़े तरंग की गती धीमी होती है, तथा इस पर AFL का जारी रहना निर्भर है। RFA चिकित्सा पद्धती व्दारा, AFL को रोकने केलिए इसी जगत्ह (डस्थमस) को अळ्लेट किया जाता है। प्रकार 9 AFL (type I AFL) के RFA की सफलता का दर $\varsigma s \%$ से भी अधिक है, एवं AFL के पुनः उत्मन्न होनेकी संभावना $90 \%$ से भी कम है। AF के RFA के मुकाबले में, AFL के RFA की सफलता का दर बहुत अधिक है । अतः केवल AFL से परेशान परिजोंकेलिए RFA चिकिज्सा पद्धती का प्रयोग निःसंदेह किया जाना चाहिए।

$34 \%$ सो $60 \% \mathrm{AF}$ के मरिजोंकी धड़कन को दवाईयोंके इलाज से पुन: ठौक किया जा सकता है। पंरतु, इस विषय में निराशाजनक बात यह है कि, द्व मास के अंदर, लगभगा $90 \%$ से $\varepsilon \circ \%$ गरिजोंमें, दवाईयों लेने के बावजूद, पुन: $\mathrm{AF}$ का दौरा पड़ सकता है। $\mathrm{AF}$ के औषधी इत्राज में, वर्ग 9 सी संमिलित (class IC) AADs [जैसे कि प्रोपाफिनॉन, (propafenone) और फ्लेकनाईंड (flecainide)] को प्राधान्य दिया गया है। वर्ग 9 सी संमिलित AADs से उपचार के दौरान, कर्ई बार, AF का AFL में परिवर्तन देखा गया हैं। पस्तु, इस बात की निश्चित संभावना कितनी है, यह अभी स्पष्ट नही है। हमनने, इस परिवर्तित नये $\mathrm{AFL}$ को पहचानने केलिए, वर्ग 9 सी AFL (class IC atrial flutter), इस नई परिभाषा को अपनाया है। 
इस प्रबंधक वितीय अध्याय में, इमने, दनार्क्ययोक बावजूद $\mathrm{AF}$ से पीड़ित उन 98 मरिजांकी (उम: $43.0 \pm 93.8$ वर्ष 92 पुर्ष) जानकासी प्रस्तुत को है, जिन में, वर्ग 9 सी संमिलित औष्धोंका प्रयोगा करते हुए (प्रोपाफिनॉन $=\rho$ मरीज़, फ्लेकनाईड $=30$ मरीज़), $\mathrm{AF}$ का $\mathrm{AFL}$ में "परिवर्तन" पाया गया। AFL को पह्चानने के वाद (वर्ग की AFL की गती $=230 \pm 2 C$ मि.से), RFA पद्धती का उपयोग किया गया। देखना यह था कि, क्या AFL के RFA के पश्चात वर्ग 9 सी दवाईयाँ लेते रहने पर, इन

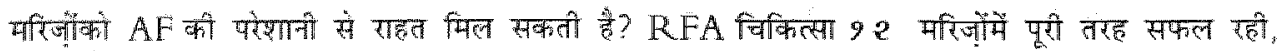
एक और मरीज़ में आंशिक रुपसे (अधिकतर) सफल रही, किंतु बचे हुए एक मरीज़ में यह चिकित्सा असफल मानी गयी। RFA चिकिल्सा के उपरांत, 9 मरीज़ को छोड़कर, बाकी सभी मरीज़ वर्ग 9 सी $\mathrm{AAD}$ ले रहे थे । औसतन \& माहके पश्चात, जिन 93 मरीज़ोंमें REA चिकित्सा कामयाब रही, उनमें से 5 मरीज़, AF तथा AFL के प्राकृतिक परिणामों से पूरी तरह मुक्त थे॥ दो और मरीज़ोंको, सिर्फ़ कुछ बार (9) और \&) $\mathrm{AF}$ के दौरे पड़े। परिणाम स्वरूप, इस मिश्र चिकित्सा प्रणाली का लाभ, इनमेंसे $\cos \%$ मरीज़ोंको पहुँच पाया। शेष दो मरीजाँको, AFL के सफल अब्लेशन के बावजूद, AFL का फिर से दौरा पड़ा। इसे फ़र एक बार सफलतापूर्वक अब्लेट किया गया। तब भी, इन दोनोंही मरीजोंको बार-बार $\mathrm{AF}$ के दौरें हालॉकी, पह्हले से कम दर में पड़ रहे थे। इस अनुभव के पश्चात हम डस निष्कर्ष पर पहुँचे कि, चाहे थोड़े समय केलिए ही सही, इस नवीन चिकिल्सा प्रणाली का प्रयोग करने से $\iota \% \% \mathrm{AF}$ से पीड़ित मरीजोंको निश्चित रूप से लाभ होगा।

प्राय:, $\mathrm{AF}$ तथा AFL, यह जलद नाड़ी के दोनों विकार एकही मरीज़ में दिखायी देते हैं। इस तरह के मरीजोंमें, AFL का अब्लेशन करने से, क्या हो रहे $\mathrm{AF}$ के दौरों पर कुछ असर पडेगा? इस प्रश्न की बारिकी से समीक्षा नही हुई है। इस प्रश्न का उत्तर पाने से यह भी निश्चित किया जा सकता हैं कि, क्या AFL और AF दोनों से ही पीडित मरीजोंमें, AFL अब्लेशन का प्रयोग करना उचित होगा?

अध्याय 3 इस प्रश्न को लोकर है कि, वे मरीज़ जों $\mathrm{AF}$ के साथक साथ प्रकार $9 \mathrm{AFL}$ का अनुभव करते हैं, क्या उनमें $\mathrm{AF}$ की तरंगें इस्थमस् (दाहिने एट्रियम में) पर निर्भर हैं? हमने, इस प्रश्न का उत्तर पाने केलिए, AFL (प्रकार 9) के सफल अबलेशन के बाद हो रहे $\mathrm{AF}$ के दर को परखा। परिणाम का विश्लेषणा करते हुए, $<2$ मरीजोंको निम्नलिखित $\&$ वर्गी में बाँटा गया:-

वर्ग 9: क्रेण AFL से परेशान ( $2 \&$ मरीज़),

वर्ग 2 : अधिक AEL और कम AF (2 2 मरीज़),

वर्ग $3:$ अधिक $A \mathbb{F}$ और कम $A F L$ (9: मरीज़) एवं

वर्ग 8: वर्ग 9 सी AFL $(9 \&$ मरीज़।

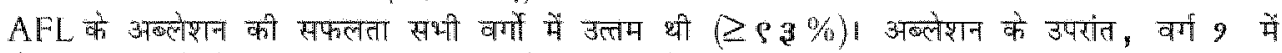

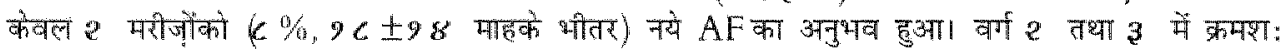
$36 \%(20 \pm 98$ माह के भीतर) और $\angle \& \%(93 \pm<$ माह के भीतर) मरीजोंको अन्लेशान के बाद $\mathrm{AF}$ के दौर पड़ रहे थे $\mathrm{AFL}$ अक्लेशान के बाद, वर्ग 8 में संमिलित $63 \%$ ( 812 माह के थीतर) मरीजोंको AF से दोबारा शिकायत नही रही। इन परिणामों से ऐसा प्रकीत होता हैं कि, AFL अंक्लेशान के कारण नखीन $\mathrm{AF}$ उत्पन्न होने की संथावना नही के बराबर है। प्रथमतः $\mathrm{AFL}$ तथा $\mathrm{AF}$ का साथा-साथ अनुभव करने वाले मरिजोंमें, $\mathrm{AFL}$ के अब्लेशान के बाद, $\mathrm{AF}$ के दौरों का दर कम होता है। परतुतु यह दर किस हद तक कम होगा, यह बात अन्लेशान सहोले इन मरिजोंमें AFL तथा AF अनुभव करने का प्रमाण क्या था, इस बात पर निर्भर है। अर्थात, प्राकृतिक परिणामोंमें अधिक लाभ, प्राय: $A F$ के दौरे कम होने बाले वर्ण (वर्ग 2, $\mathrm{AEL}>\mathrm{AF}$ ) में ज्यादा है। इस जानकारी से ऐसा लगता है कि, $\mathrm{AFL}$ तथा $\mathrm{AF}$ का साथ-साथ अनुभव करने वाले मरिजोंमें, $\mathrm{AF}$ के तरंगों के कायम रहने में इस्थमस् का संभाग महुत्वपूर्ण है। वर्ग 9 सी AFL का अबलेशन से इलाज, यह $\mathrm{AF}$ की चिकित्सा पद्धती में एक नया कद्म माना जाना 
चाहिए। दृद्य की विशिष्ट जगह को अन्लेशन द्वारा सफलतापूर्वक इलाज का लक्ष्य बनाने केलिए $A F$ के मरिजोंका योग्य चग्य करना जरुरी है।

इलाज के एक से अधिक पद्धतियोंका प्रयोग करने पर, AF पर अधिक नियेत्रणा पाया जा सकता है। इस इलाज पद्धती को हायब्रिड (hydrid सा संकरित) चिकित्सा प्रणाली भी कह सकते है। आगर AF की हरंगों "नियंत्रित" (organized AF) रुप में हो तो, अब्लेशन, डिफिक्रिलेशन अधवा पेसिंग यह उपचार पद्धतियोंका बेहतरीन प्रयोग किया जा सकता है। अध्याय दो में $\mathrm{AF}$ को इलाज केलिए योग्य, एक नयी और सफल चिकिताप्रणाली का विवरण किया गया है। इस तरह से इलाज करना तब ठीक होगा, जब कि, अब्लेशन चिक्तिता के उपरांत $\mathrm{AF}$ के दौरों पर लंबे समय केलिए नियंत्रणा किया जा सके। यह बात स्पष्ट है कि, इलेक्ट्रोकार्डिओग्राम (electrocardiogram, ECG) यह AFL को जाँचने का उत्तम बरीका हैं। अध्याय \& इन सवालों को लेकर था कि :9) वर्ग 9 सी AFL के ECG तथा इल्लेक्ट्रोफिजिओलॉजी (electrophysiology) जाँचके परिणाम क्या थे? तथा 2) क्या वर्ग 9 सी AFL अब्लेशान चिकित्सा प्रणाली, $\mathrm{AF}$ के दौरों पर लंबे समय केलिए नियंत्रण पा सकती है? इस विषय में हमने 28 मरीजोंकी (उप: $58 \pm 92$ वर्ष, 98 पुरुष) समीक्षा की। इन मरिज़ोंमें, वर्ग 9 सी संमिलित AAD लेते हुए (प्रोपाफिनाँन $=92$ मरीज़, फ्लेकनाईड $=92$ मरीज). $\mathrm{AF}$ का एक नये $\mathrm{AFL}$ में परिवर्तन देखा गया। $\mathrm{ECG}$ को फिरसे जाँचने पर यह दिखायी दिया कि, AFL 93 मरिजोंमें टियिकल (typical AFL, आम तरह का) तथा $C$ मरिजोंमें एटिपिकल (atypical AFL, भिन्न तरह का) था। शेष 3 मरिज़ोंमें कोर्स् (coarse) AF तरह का था। इस्थमस् में चलन की गती (isthmus conduction time) बाहर से अंदर की दिशा में (atreromedial direction), इसके विरुध्द दिशासे (mediolateral direction), कम (धीमी) थी $(908 \pm 32$ मि. से मुकाबले $0.5 \pm 38$ मि.से, $p=0,023)$ शायद इसीलिए, अधिकाश वर्ग ? सी AFL कांऊटर क्लॉकवाईज (counterclockwise, घड़ी के विरुध्द) दिशा में शे सभी टिपिकल AFL तथा $s$ में से $\&$ एटिपिकल AFL कांटर क्लॉकवाईज्ज थे। इ्न दोनों ही तरह के AFL में, अक्लेशन की सफलता उत्तम और एक सी थी (टियिकल AFL $82 \%$ तथा एटिपिकल AFL $900 \%$ ) अब्लेशन के बाद, लंबे समय तक $(9 \pm \xi, \varepsilon-2 \&$ महीनोंतक $)$ इन मरीजोंकी नियमित रुप से जाँच की गई। इस जाँच के दौरान यह देखा गया कि, टिपिकल $(93$ में से 99 मरीज़) या एटिपिकल (C में से 8 मरीजा) वर्ग 9 सी $\mathrm{AFL}$ को अन्लेट करनेके बाद, $\mathrm{AAD}$ के पुनः प्रयोग से $\mathrm{AF}$ के दौरों पर कुछ मरिजोंमें ज्यादा अच्छा काखू किया जा सकता है। परंतु कोर्स् $\mathrm{AF}$ को तीनोंही मरीजोंमें, $\mathrm{AF}$ पर काबू पाना पहले जितना ही कठीन रहा। संक्षेप में, वर्ग \% सी AFL, ECG रुप में, टिपिकल अथवा एटियिकल हो सकता है। यह दोनोंही तरह के AFL के तरंगो का पृध (macro-reentrant circuit) दाहिने एट्रियम में स्थित है त्या इस्थमस् पर निर्भर है। हायव्रिड इलाज पद्धत्धती का प्रयोग करने से, टिषिकल प्रकार के वर्ग $\%$ सी AFL के मरिजोंमें, लंबे समय तक $\mathrm{AF}$ कोरोंपर काबू पाया जा सकता है। यदि इन मरिजोंों $\mathrm{ECO}$ पर कोर्स $\mathrm{AF}$ पह्रचानी जाय, तो हायत्रिड इलाज पद्धती का अवलंब नही करना चाहिए।

वर्ग 9 सी AAD लेते हुए, AF के किन मरीजोंमें और कितने हद तक AFL में परिवर्तन देखा जाप्गा, यह बात निश्चित नही है। ऊसी तरह, इस परिवर्तन को देखने से पहले, वर्ग 9 सी दवाई का किस मात्रा में और कितने दिनों तक उपयोग करना जस्री है, यह भी पूरी तरह मालूम नहीं है। यह भी जानना जरूी है कि, क्या वर्ग 9 सी AAD लेते हुए मरीजको नब्ज की कोई अन्य समस्या उत्पन्न हो सकती है? इन प्रश्नोंको मध्यनजर रखते हुए, यह स्पष्ट होना जरूरी है कि, इस इताज प्रणाली का निश्चित लाभ, मरीजोंकी अधिक संख्यामें तथा काफी लंबे समय के बाद किताना है?

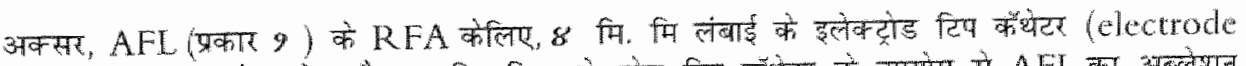
tip catheter) का प्रयोग होता है। $C$ मि. मि. इलेक्ट्रोड टिप कथेटर के उपयोग से AFL का अन्लेशान इस विष्य पर विधीयूर्वक अध्ययन नही हुआ है। इस प्रबंध के 5 वे अथ्याय में, 30 मरिजोंमे, प्रकार? 


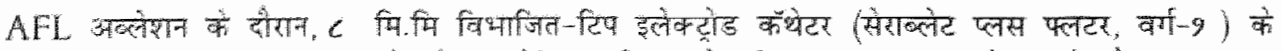
उपयोग की तुलना \& मि. मि इलक्ट्रोंड कैथेटर (वर्ग २) से की गयी। AFL अब्लेशन को दौरान, इस्थमस्

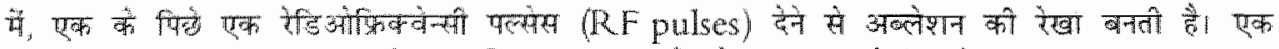

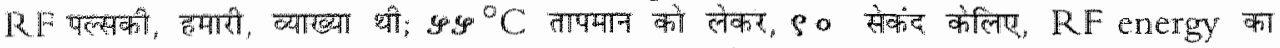
उपयोगा अब्लेशन चिकित्सा, वर्ग 9 के सभी तथा वर्ग 2 के अधिकतर $(94$ में से 98 मरिज) मरिजोंये सफल रही। $C$ मि.मि विभाजित-हिप इलेक्ट्रोड का उपयोग करने से कम RF पल्सेस (वर्ग $9: 92 \pm 3 y$ सुकाबले वर्ग $2: 26 \pm 5 ; p<0.0009$ ) और कम फ्लुरोस्कोपी समय (flouroscopy time, वर्ग 9 : $23 \pm 93$ सिनिट पुकावले वर्ग $2: 84 \pm 2 c$ मिनिट; $p=0.09)$ का प्रयोग करना पड़ा। लगभग उतने हो समय के उषराँात ( वर्ग $9: 83 \pm 2<$ महीने मुकाबले वर्गा $2: \&< \pm 2$ महीने), केवल 9 मरीज (वर्गा 2) को दोबारा $\mathrm{AFL}$ का दौरा पड़ा। इन परिणामों से यह बात स्पष्ट है कि, $\mathrm{AFL}$ अब्लेशन केलिए $C$ मि.मि विभाजि-टिप इलेक्ट्रोड का प्रयोग श्रेष्ठ है।

सफल AFL अज्लेशन केलिए, इस्थमस् में अब्लेशन की रेखा बनाना जरुरी है। ऐसा करने पर, इस्थमस् मे. दोनों ही दिशाओंमें, तरंगों का कंडकशन (conduction, चलन) बंद होता है। इसे बायडायरेक्शनल कंडकशन ब्लॉक (bidirectional conduction block, BIC block) कहते है। यही, AFL के अक्लेशन चिकित्सा का सर्वोत्तम ध्येय माना जाता है, क्योंकि ऐसा करने पर दोबारा AFL निर्माणा होने की संभावना बहुत ही कम है। इसी कारण, $\mathrm{BIC}$ ब्लॉक का लंबे समय केलिए बने रहना जरुरी है। अध्याय $\varepsilon$ में हुमने इस ब्यात की परिक्षा की, क्या प्रथमतः BIC ब्लॉक साध्य होने के पश्चात, आयसोपोटेरेनॉल (isoproterenol) का उपयोग करने से $\mathrm{BIC}$ ब्लॉक कायम रहता है? और क्या, इस तरह $\mathrm{BIC}$ क्लॉक कायम रहने से, आगे चलकर AFL के दोबारा होने की संभावना और भी कम हो सकती है? इस विषय को जाँचते हुए, $\mathrm{AFL}$ के $8 \&$ मरिज़ोंम; पोस्टेरियर (posterior, $2 \mathrm{~s}$ मरीजा) सेप्टल (septal, \& मरोज़) तथा दोनोंही $(99$ मरीजा) इस्थमस् का अक्लेशन किया गया। अब्लेशन के उपरांत, इन सभी मरिजोंमें, AFL उत्पन्न नही किया ज्ञा सका, तथा $\mathrm{BIC}$ ब्लॉक सिध्द था। इसके बाद आयसोप्रोटेरेंॉल 9 3 मायकोग्राम/भि.) का उपयोग किया गया। इस पर यह देखा गया कि, 88 में से 6 मरिजोंमें इस्थमस् में कंडकशन फिर शुरु हुआ (reversal of BIC block); $\&$ मारिजोंमें इस्थमस् के दोनों दिशाओं में तथा 9 मरीज़ में सिर्फ एक दिशा में शुरु हुआ। 6 में से 8 मरिजोंमें, फिर एक बार, AFL उत्पन्न हुआ। BNC ब्नॉक को फिरसे हासील करने केलिए अतिरिक्त 2 - से - 28 (मिद्डियन- 8 ) RF पल्सेस का उपयोग करना पड़ा। इसके बाद, इन सभी मरिजोंकी औसतन $63 \pm 6 \%$ महीनोंतक (2-39 महीने) नियमित जाँच हुई। इस समय में, 2 मरिजोंको $(8,4 \%)$ दोबारा $\mathrm{AFL}$ का दौरा हुआ। सारांश में, यह हो सकता है कि, अब्लेशन के उपरांत इस्थमस् में नॉनयुनिफॉर्म अँनआयसोट्रोपिक कंडकशन (non-uniform anisotropic conduction) अधिक हो रहा हो। इस कारण, इस्थमस् में हो रहे बहुत ही धिमें कंडक्शन को (slow conduction), हमने, कडकशन का पूरी तरह बंद होना समझा। आयसोप्रोटरेनॉल का उपयोग करने से, इस्थमस् के कंडकशन में दोबारा शुरुवात हुई, जिसे पहचान लिया गया। इस्थमस् में कंडक्शन बलॉक AFL को रोकने केलिए जरुरी है। RFA विधी के बाद आयसोप्रोटेरॉन का प्रयोग BIC block को निश्चित करने केलिए जरूरी है। इस अध्ययन में, दोबारा $\mathrm{AFL}$ के दौरों का दर बहुत कम था, और यह बात आयसोप्रोटेरोनात के उपयोग को औरभी महत्व दती है।

अध्याय 6 में, दो अभ्यासनीय अनुभवोंका विस्तार से वर्णन किया गया है, और इस विषय की विस्तार से चर्चा की गयीं है। यह अनुभव, आयडियोपथिक वेन्ट्रीक्युलर टैकिकार्डिया (idiopathic ventricular tachycardia) से पीड़ित दो मरीज़ोंके साथ हुआ। पहला अनुभव यह था कि, दोनोंही मरिजोंमें इलेक्ट्रोफिजिओलॉजी परिक्षा के दौरान, वेन्ट्रीक्युलार टँकिकार्डिया की शुरूवात $\mathrm{AF}$ के कारण हुई। दुसरा, हृदयमें वेन्ट्रीक्युलर टैकिकार्डिया और AF के साथ-साथ होने के दौरान कैच्चर और फ्युजन बीट्स (capture and fusion beats) देखे गये। यह दोनोंही बातें बहुत कम देखने में आती है, इसलिए रोचक भी है। 


\section{Acknowledgements}

I find it very gratifying to write an acknowledgement to this thesis. "A teacher affects etemity". It has been my continued good fortune to have benefited in many academic, professional and personal ways at the Departments of Cardiology, Academisch Ziekenhuis Maastricht, Maastricht, The Netherlands and King Edward VII Memorial Hospital, Mumbai, India.

The present work could not have been accomplished without the constant help of the gum, Professor Hein JJ Wellens. Professor Wellens is my promotor and has been the four de force. My deepest gratitude goes to him, for accepting me to train in his department as a Fellow in Clinical Cardiac Electrophysiology and later providing the possibility to work on this thesis. Without his astute reading of the manuscript and eloquent editing of the text this thesis would not have been the one it has become. His continuous support and guidance have provided all the inspiration necessary to undertake this work. Professor Wellens, I am proud to be a pupil from your school.

I shall remain indebted to Dr Iuz-Maria Rodriguez, who is my co-promotor. From the very beginning and until it was time for the samtenatting, she has shared the burden of this challenge. She has constantly motivated me, given me her time, allowed me a due trial and error, warned me of deadlines and kept me organized. She has been with me, both during times of excitement and frustration. Luz, you have been the mainstay and by your continuing interest and a step-by-step approach you have moved this thesis from faith to veality.

Over the past 2 years, I have had a very rewarding opportuniry to work closely and collaboratively under Dr Joep LRM Smeets. He skillfuily provided a stimulus to leaming by regularly quizzing with the ellectrocardiograms and during every electrophysiological study, teaching a logical way of interpreting electrograms (Joep, in your own words, available for free). His questions always carried a thist. Joep, all this provoked thinking and everytime taught me a bit more.

I heartily extend my gratitude to Dr Carl Timmermans for his guidance, comoperation and unflagging encouragement during the assembly of this thesis. Carl, over this period, you have been very busy with your thesis but you could find time to help me.

I am thankful to Dr Barbara Dijkman-Domanska and the new doctor Paul Volders for their skilled and untiring assistance. Barbara and Paul are my paranimphs during the defense of this thesis. 
I have benefted enomously from the experience and opinions of the staff members of the Afdeling Cardiologie, AZM. Discussions and teachings at the morning meeting have served as regular updates. I also thank Professor Adelin Albert and Dr Willem Dassen for their help with statistical analysis of the data.

It has been a considerable honour to have Professor MA Allessie, Professor HJGM Crjns, Protessor J Farré, Professor RS Reneman and Dr Marc Vos, all experts in the field of electrophysiology and with a major international reputation, to review this work.

I will always owe a deep gratitude and appreciation to my alma water, King Edward VII Memorial Hospital, Mumbai, India. From the time Professor Hema L. Kulkarni accepted me in her department, as a Registrar in Cardiology, she has been kind and provided all the guidance. Madam, under your direction, I have benefited from an exposure to a wide cross-section of Clinical Cardiology. It has been a privilege to have learned and worked in a favorable and creative environment that exists at KEM.

I owe a particular debt to Dr Yash Lokhandwala. After his return from Maastricht, he has successfully pioneered the EP program at KEM, and his work in Mumbai provided me with the stimulus for the study of cardiac electrophysiology. Yash, I am grateful to you for your vote of confidence, which set me on the road to Maastricht, and hope you feel it was not misplaced.

My special thanks are expressed to Professor PA Kale, for supervising my training in Cardiology. I am also grateful to Dr Bharat Dalvi, for teaching me the principles of congenital heart disease and color Doppler echocardiography. BVD, at all times, you have infused a lot of enthusiasm and painstakingly corrected my attempts at scientific writing. Dr Prafulla Kerkar, thank you for the umpteen small but valuable tips that you have taught during the catheterization procedures. PGK, I would not forget the way you maintain clinical relevance in all decision making. It has been my pleasure to work with Dr Amit Vora and Dr Sunil Sathe, both of whom have guided me from time to time, including with my efforts to leam electrophysiology.

I also wish to thank Professor GH Tilve and Professor Satyavan Sharma for favoring me with their recommendation.

Fellowship in Maastricht brought a chance to be closely associated with Drs Barbaros Dokumaci, Dan Iosifescu, Hakan Tikiz, Klaus Kattenbeck, Lenises de Paula, Mauricio Cabaralles, Michalis Efremidis, Namik Eryol, Ravinder Kumar Batra, Sedat Köse, Stavros Lyropoulous and Tchavdar Shalganov. Informal discussions during the electrophysiology study helped us to understand, organize and express this knowledge better. Similarly, exchange of ideas at the annual scientific sessions of the American Heart Association, American College of Cardiology and European Society of Cardiology have been of immense value. 
The excellent figures that have beer published in this thesis were possible, thanks to the elegant artwork of Adri van den Dool. Geertjan (van Zonneveld) and his colleagues from the Medische Fotografie and Andiovisule Dietst, AZM deserve a special mention, for the enthusiasm and efficiency with which they performed all the digital work for the illustrations. Geertjan, thank you for creating a wonderful cover page! The summary in Hindi could not have been inciuded without the much needed help of Dr Ravinder Kumar Batra (New Delhi). It is my pleasant duty to thank everybody at the Dotanyse, especially Ruud Leliveld, for performing the incredible task of getting this book ready on time.

I gratefully thank all the Secretaries of the Afdeling Cardiologie, AZM. I have received help from all of you, at some time or the other, with secretarial, administrative or at times even personal work. I wish to acknowledge the direct co-operation of the nursing and technical team in the EFO kamer. Bert (van der Steld), your friendly appearances in the EFO kamer were most welcome, as was your technical help with the EMS. Thanks are due to the staff in the policlinic, library, facilitair meldpunt, print shop, copy shop, and the guest house University Maastricht, for helping me in one way or another.

A wonderful camaraderie was struck in the $Y$-ruimte, nito 2 , thanks to the enthusiasm of Domien Engelen, Paul Volders, Jurren van Opstal and Dirk Donker. Jet Leunissen, thank you, for allowing me to copy from the JCE's, time and again!

Thanks are due to friends; Dr Nitin Deshpande, Professor Suresh and Radha Ankolekar, Vipin and Payal Moharir, Yogesh and Anuradha Joshi and Abhinay Diwale. Because of you all, Vaishali and myself did not miss home, as much as we would have had without you.

This idea would have never taken a concrete shape, had it not been for the research grant $I$ have received from the Wijnand $M$. Pon Foundation, Leusden, The Netherlands. I would also like to express my gratitude to; The Lotus Trust, RD Sethna Scholarship Fund, Sir Ratan Tata Trust and Nanabhoy Jeejecbhoy Charity Trust, all Mumbai, India who have provided scholarships towards my Fellowship in Maastricht.

Lastly, my gratitude is towards my family, both Nabar's and Tilve's, for their support, patience and forberance. Sou. Aai, Ti. Dada and Vivek, thank you for spending time with us in Maastricht. It was very relaxing for us and we hope you enjoyed while being here. Dearest Vaishali, will it be enough if I said THANK YOU? Ik denk het niet? 



\section{Curriculum Vitae}

\section{Ashish Ashok Nabar}

Born Mumbai, Maharashtra, India. May 26, 1967.

Nationality Indian

Marital Status Married

1972-1982 Primary and Secondary School, Shrimati Surajba Vidya Mandir, Jogeshwari, Mumbai, India.

1982-1984 Junior College (Science), Parle College, Vile Parle, Mumbai, India. 1984-1989 M.B.,B.S. University of Bombay, Mumbai, India. Seth Gordhandas Sunderdas Medical College, Parel, Mumbai, India

1989-1990 Rotating Internship; King Edward VII Memorial Hospital, Dr RN Cooper Hospital and NM Wadia Maternity Hospital, Mumbai, India.

1990-1993 MD (Internal Medicine). University of Bombay, Mumbai, India. Residency in Internal Medicine and Allied specialities (Cardiology, Neurology, Gastroenterology, Nephrology, Intensive Care and Rheumatology). Department of Medicine, King Edward VII

1993-1996 Diplomate of National Board (Cardiology). National Board of Examinations, New Delhi, India.

Registrar in Cardiology, Department of Cardiology, King Edward VII Memorial Hospital, Mumbai, India. (Professor HL Kulkarni)

1996-1997 Clinical Associate and Research Officer, Department of Cardiology, King Edward VII Memorial Hospital, Mumbai, India. (Professor HL Kulkarni)

1998-2000 Fellowship in Clinical Cardiac Electrophysiology, Department of Cardiology, Academic Hospital Mastricht, Maastricht, The Necherlands. (Professor HJJ Wellens) 



\section{List of Publications}

\section{Original Articles}

1. Nabar A, Bhatia SJ, Abraham P, Mistry FP. Total and segmental colonic transit time in non-ulcer dyspepsia. Indian J Gasmonterol 1995;14:131-133.

2. Naik AM, Nabar AA, Lokhandwala YY, Kulkami HL, Deshpande JR, Sivaraman A. Is hemorthagic myocardial infarction more common with streptokinase? Ind Heart J 1997:49;387-390.

3. Ranjan A, Lokhandwala YY, Vora AM, Naik AM, Nabar AA. Scope and afficacy of complex radiofrequency ablation. Ind Heart J 1998;50:193-198.

4. Dalvi B, Nabar A, Goyal V, Naik A, Kulkarni H, Ramakanthan R. Transcatheter closure of patent ductus arteriosus in children weighing $<10 \mathrm{~kg}$ with Gianturco coils using the balloon occlusion technique. Cathet Cardiowast Diagn $1998 ; 44: 303-308$

5. Nabar A, Rodriguez LM, Timmemans C, Smeets JLRM, Wellens HJJ. Radiom frequency ablation of "class IC atrial flutter" in patients with resistant atrial fibrillat tion. Am J Cardiol 1999;83:785-787.

6. Nabar A, Rodriguez LM, Timmermans $\mathrm{C}$, vd Dool A, Smeets JLRM, Wellens HJI. Effect of right atrial isthmus ablation on the occurrence of atrial fibrillation: Observations in four patient groups having type I atrial flutter with or without associated atrial fibrillation. Circulation 1999; 99:1441-1445.

7. Nabar A, Rodriguez LM, Timmemans C, Smeets JLRM, Wellens HJ]. Isoproterenol to evaluate resumption of conduction following right atrial isthmus ablation in type I atrial flutter. Circulation 1999;99: 3286-3291.

8. Timmermans C, Nabat A, Rodriguez LM, Ayers G, Wellens HJJ. Use of sedation during cardioversion with the implantable atrial defibrillator. Cirnlation 1999; 100;1499-1501.

9. Lokhandwala YY, Vora AM, Naik. AM, Nabar A, Kavthale, S. Dual morphology of idiopathic ventricular tachycardia. J Cardionas Eedrophysiol 1999;10:1326-1334.

10. Rodriguez LM, Nabar A, Timmermans $C$, Wellens HJJ. Should we prefer a long tip electrode to perform radiofrequency ablacion of type I atrial tutter? Results of a prospective randomized study comparing an 8-mm split-tip versus a 4 -mm tip ablat tion catheter. Am J Cardiol 2000; In Press.

1. Nabar A, Rodriguez LM, Timmermans $C$, van Mechellen $R$, Wellens HJJ. Electrocardiographic and electrophysiological findings and their inportance on long-term outcome after right atrial isthmus ablation. (smbmitted for publication) 


\section{Case Reports}

1. Jadhay MN, Nabar A, Lokhandwala Y. Electrocardiographic Diagnosis. J of Applied Medicine, June 1992.

2. Vora A, Kerkar P, Kulkarni H, Nabar A, Dalvi B. Percutaneous balloon mitral valvuloplasty by the retrograde (Babic) technique in a patient with inferior vena cava stenosis (letter to editor). Cathet Cardionasc Diagn 1995;36:291-292.

3. Fulwani M, Nabar A, Lokhandwala YY. Blade-balloon atrial septostomy in primary pulmonary hypertension - a case report. Ind Heart J 1997;49:185-186.

4. Naik AM, Lokhandwala YY, Nabar AA, Dalvi BV. Catastrophic WPW syndrome in a 13 month child- cure by radiofrequency ablation. Indian Pediatrics 1997;34:931-937.

5. Naik AM, Nabar A, Dalvi BV. Double outlet left atrium: a case report. Ind Heart] 1997;49:418-420.

6. Gupta A, Nabar A, Lokhandwala YY. Hemorrhage resulting in isolated myocardial infarction without coronary atherosclerosis in a young lady. Ind Heart $J$ 1997;49:450-451 (Letter to editor)

7. Nabar A, Vora A, Lokhandwala Y. Emergence of bidirectional accessory pathway conduction in adulthood. J Cardiovase Electrophysiol 1998;9:648-65.

8. Nabar A, Rodriguez LM, Timmernans C, Kattenbeck K, Wellens HJJ. Capture and fusion beats during atrial fibrillation and ventricular tachycardia. (submitted for publication)

\section{Dissertation}

Nabar A, Patel KC. Total and segmental colonic transit time in non-ulcer dyspepsia. Dissertation accepted by University of Bombay for the award of MD (General Medicine), 1993.

\section{Abstracts}

1. Nabar A, Shah A, Karnad D, Doiphode S, Tilve GH. Effect of stopping the use of gentamicin on the sensitivity of gram negative respiratory pathogens to amikacin and gentamicin. Presented at the Xth National Conference of Respiratory diseases (Abstract issue) 1990.

2. Narula D, Kerkar P, Vora A, Gupta S, Banker D, Nabar A, Shah C, Kulkarni H. Balloon dilatation of modified Blalock-Taussig shunts. Ind Heart J 1994;46:220.

3. Vajifdar B, Shali C, Vora A, Kerkar P, Lokhandwala Y, Dalvi B, Nabar A, Banker $D$. Three years follow-up after percutaneous balloon pulmonary valvuloplasty. Ind Hean J 1994:46:226. 
4. Sathe S, Vora A, Kerkar P, Lokhandwala Y, Nanula D, Nabar A, Banker D, Kulkami H. Radiofrequency catheter ablation for tachyarhythmas: an intial experience. Ind Heart J 1994;46:226.

5. Kale P, Vora A, Kerkar P, Banker D, Kulkami H, Gupta S, Nabar A, Dalvi B. Percutaneous mitral valvuloplasty in juvenile mitral stenosis: intermediate rem follow-up. Ind Hean J 1994:46:226.

6. Gupta S, Gupta S, Pandit RB, Kerkas P, Nabar A, Kulkami H, Shah C, Narula D. Magnesium and acute myocardial infarction. Ind Heart J 1994;46:263.

7. Nabar A, Bhatia S], Abraham P, Shah P, Mistry FP. Colonic transit time in non-ulcer dyspepsia. World Congress of Gastroenterology, Los Angeles Callifomia, USA. (Abstrat issu, page 1109); 1994.

8. Nabar A, Dalvi B, Lokhandwala $Y$, Vajifdar B, Goyal V, Shah P, lyer R, Kulkarni H. Congenital anomalies of the coronary arteries - diagnosis by color Doppler echocardiography. Ind Heart I 1995;47:570.

9. Dalvi B, Vora A, Ramakanthan R, Bandekar V, Narula D, Nabar A, Shah P. Kulkanni H. Non-coronary use of stents. Ind Hear J 1995,47:570.

10. Nabar A, Iyer R, Vora A, Narula D, Banker D, Dalvi B, Kulkarni H. Aneurysms of the sinus of Valsalva. Ind Hearif $1995,47: 570$.

11. Nabar A, Vora A, Kerkar P, Lokhandwala Y, Dalvi B, Narula D, Kulkarri H. Transcatheter retrieval of therapeutic occlusion devices. Ind Heart J 1995;47:570.

12. Vora A, Sathe S, Lokhandwala Y, Nabar A, Narula D, Vajfdar B, Groyal V, Dalvi B, Kulkarni H. Radiofrequency ablation of accessory pathways. Ind Hiar J 1995;47:582.

13. Nabar A, Dalvi B, Tendolkar A, Simha P, Shalı C, Vajifar B, Kulkarni H. Fontan circulation: a color Doppler echocardiography study. Ind Heart J 1995;47:583.

14. Shah P, Dalvi B, Vora A, Nabar A, Goyal V, Iyer R, Kulkarni H. Pulmonary venous wedge: does it correlate with pulmonary artery pressure? Ind Heant J $1995 ; 47.595$.

15. Dawi B, Nabar A, Vona A, Banker D, Vajifar B, Kulkani H. Color Doppler echocardiography in evaluation of Sideris butroned device. Ind Hear J 1995:47:603.

16. Shah P, Narula D, Nabar A, Goyal V, Vora A, Jyer R, Davi B. Echocardiography guided balloon atrial septostomy. Ind Heat J 1995:47:604.

17. Goyal V, Lokhandwala Y, Kerkar P, Banker D, Shah C, Nabar A, Dalvi B. Validation of echocardiography in the determmation of pumonary artery anatomy and size in cyanotic congenital heart disease. Ind Hean J 1995;47:619.

18. Sathe S, Lokhandwala $\mathrm{Y}$, Vora A, Iyer R, Narula D, Nabar A, Vajifdar B, Kulkami H. Electrophysiologic properties of the AV node after radiofrequency catheter ablation of slow pathway for AV nodal reentrant tachycardia. Ind Hean J 1995:47:621.

19. Vora A, Nabar A, Narula D, Lokhandwala $Y$, Banker D, Sathe S, Shah C, Iyer $\mathbb{R}$. Radiofrequency catheter ablation for idiopathic ventricular tachycardia. Ind $H \mathrm{com}^{\mathrm{J}}$ $1995 ; 48: 649$.

20. Nabar A, Narula D, Rodriguez C, Soren D, Vora A, Lokhandwala Y, Dalvi B, Kulkarni $H$, Ghosh K, Mohanty D. Is there a prethromobtic state in left atrial blood 
in meumatic mitral stenosis? Ind Hear J 1996:48:552 finalist for the Prof DP Basu mewomil awad at the $48^{\text {th }}$ Amnual conference of the Cardiological Society of India.

21. Nabar A, Fulwani M, Naik A, Ranjan A, Charantimath M, Shah P, Dalvi B. Dingnosis of total anomalous pulmonary venous drainage by color Doppler echocardiography. Ind Hean J 1996;48:538.

22. Kerkar P, Goyal V, Nabar A, Jijna F, Pathare A, Naik A, Dalvi B. Hemolysis following PDA coil closure by coll embolization. Ind Hean J 1996; 48.541.

23. Fulwani M, Narula D, Kulkarni H, Kerkar P, Nabar A, Vajifdar B, Dalvi B. Balloon pulmonary walvotomy in Tetralogy of Fallot: initial results. Ind Heart J $1996 ; 48: 542$.

24. Kulkarni H, Iyer R, Nanula D, Lokhandwala Y, Goyal V. Shah C, Nabar A. Radiofrequency ablation of atypical AV nodal reentrant tachycardia. Ind Heari I $1996: 48: 494$

25. Goyal V, Nair N, Goyal Vinay, Patel R, Nabar A, Kulkami H, Dallvi B. Radionuclide lung studies following coil embolization of patent ductus arteriosus. Ind Heart J 1996:48:494.

26. Ghosh K, Mohanty D, Shetty S, Phillips C, Soren D, Bharucha K, Nabar A, Kulkami H. Is there a prethrombotic state in left atrial blood in rheumatic mitral stenosis. At the $14^{\text {th }}$ International Conference on Thrombosis, Montepellier, France. 1996.

27. Nabar A, Ranjan A, Vora A, Lokhandwala $Y$. Radiofrequency ablation-spectrum and efficacy. At the $4^{\text {th }}$ Conference of the Indian College of Cardiology, Abstract issuc) 1997.

28. Ranjan A, Nabar A. Vora A, Lokhandwala YY. Complex radiofrequency ablation. Presented at the $4^{\text {th }}$ Conference of the Indian College of Cardiology, (Abstractissue) 1997.

29. Lokhandwala $Y$, Nabar A, Iyer R. New observations during radiofrequency ablation for idiopathic ventricular tachycardia. Pacing Clin Electroplysiol 1997;20(Part II): 2317

30. Kerkar P, Goyal V, Khan A, Naik A, Nabar A, Garasia M, Ramakanthan R, Dalvi B. Transcatheter closure of patent ductus arteriosus in chiddren weighing $<10 \mathrm{~kg}$ with Gianturco coils using temporary balloon occhsion technique. Ind Hear J $1997: 49: 597$

31. Gupta A, Shah P, Ranjan A, Vajifdar B, Nabar A, Lokhandwala Y, Kulkarni H. Simple new electrocardiographic signs to differentiate between right coronary and left circumflex artery occlusion in inferior wall infarction. Ind Heart $\int 1997 ; 49: 602$.

32. Shah P, Vajifdar B, Fulwani M, Nabar A, Vora A, Lokhandwala Y, Kerkar P. Age at onset and gender distribution of atrioventricular nodal tachycardia and atrioventricular reentrant tachycardia. Ind Heart I 1997;49:609.

33. Kawthale S, Shah P, Natk A, Goyal V, Nabar A, Vora A, Kerkar P. Intra-arterial blood pressure changes during atrioventricular nodal tachycardia and atrioventricular reeentrant tachycardia. Ind Heart J 1997;49:609. 
34. Vona A, Fulwani M, Nak A, Iyer R, Nabar A, Kulkami H. Intermediate tem follow-up after radiofrequency ablation of accessory pachways. Ind Heart $\mathrm{I}$ $1997,49: 610$

35. Tyer R, Vajifdar B, Nabar A, Goyal V, Dalvi B, Kulkani H. Differences in velocity and gradients recorded by four different frequency Doppler transducers. Ind HearI 1997:49:613.

36. Fulwani M, Gupta A, Iyer R, Nabar A, Lokhandwala $Y$, Kerkar P, Kulkami H Can sinus thythm be restored in patients with chronic atrial fibrillation after balloon mitral valvotomy. Ind Heart ] 1997,49:620.

37. Goyal Vimay, Nair N, Goyal V, Nabar A, Patel R, Dalvi B. Use of tadionuclide lung scintigraphy for assessment of pulmonary perfusion in patients with coil closure of patent ductus arteriosus. Ind Heart J 1997;49:620.

38. Nabar A, Fulwani M, Vajifdar B, Deshpande J, Sivaraman A, Dalvi B. Echocardiographic assessment of coronary artery anatomy in transposition of great arteries. Ind Heart] 1997;49:652.

39. Iyer R, Goyal VG, Nabar AA, Lokhandwala YY, Is there a change in AV Wenckebach after ablation of slow pathway for AVNRT dependent upon presence of demonstrable duality. Paing Cin Eleorophysiol 1997:20:2345.

40. Nabar A, Rodriguez LM. Timmermans C, vd Dool Adri, Smeets JLRM, Wellens HJJ. Radiofrequency ablation of "class IC atrial flutter" in patients with resistant atrial fibrilation. Circulation 1998;98:2976. At the $71^{\text {st }}$ Annual Scientific Sessions of the American Heart Association, Dallas, Texas, USA. 1998.

41. Nabar A, Rodriguez LM, Timmenmans C, vd Dool A, Smeets JLRM, Wellens HJJ. Effect of right atrial isthmus ablation on the occurrence of atrial fibrillation : Observations in four patient groups having type I atrial futter with or without associated atrial fibrillation. I Am Coll Cardiol 1999;33:117A. At the 48 $8^{\text {th }}$ Annual Scientific Sessions of the American College of Cardiology, New Orleans, Lousima, USA. 1999.

42. Rodriguez LM, Timmermans C, Donker D, Smeets J, Nabar A, Kattenbed K, Wellens HJJ. In contrast to the right atrium tho right ventricle does not show electrical remodelling during atrial fibrillation. Pacing and Clin Elcchophysiol 1999,22:794. At the 20 Annut Scientific Sessions of the Nomt Americun Society of Pacing and Electrophysiology, Toronto, Canada. 1999

43. Nabar A, Rodriguez LM, Timmernans C. Smeets JlRM, Wellons HIJ Isoproterenol to evaluate resumption of conduction following right atrial isthmus ablation in type L atrial lutter. Eur J Cardol 1999:20:99. At the $21^{\text {st }}$ Annual Scientifu Sessions of the European Society of Cardiology, Barcelona, Span. 1999.

44. Nabar A Rodriguez LM, Timmemans C, Wellens HIJ. Electrocardiographic pattems of tutter wave in "class IC atrial futter". Eur J Cardiol 1999,20:100. Ar the 21 st Annual Scientific Sessions of the European Socicty of Candiology, Barcelona, Span 1999.

45. Nabar A, Rodriguez LM, Timmemans C, Wellens HJJ. Electrophysiology of "class IC atrial flutter". Eur J Cardiol 1999,2099. At the 21" Anmual Scientific Sessions of the European Society of Cardiology, Barcelona, Spain. 1999. 
46. Timmermans $C$, Masset S, Rodriguez LM, Ayers $G$, Lambert $H$, Nabar A, Wellens HJj. Comparison of a new 2-lead system with a 3-lead system for atrial defibrillation. Eur Cardiol 1999;20:108. At the $21^{\text {st }}$ Annual Scientific Sessions of the European Society of Cardiology, Barcelona, Spain. 1999.

47. Rodriguez LM, Nabar A, Timmermans C, Wellens HJJ. Should we prefer a long tip electrode to perform radiofrequency ablation of type I atrial flutter? Results of a prospective randomized study comparing a 8-mm split-tip versus a 4-mm tip ablation catheter. Circulation 1999 (In Press). At the $72^{\text {nd }}$ Annual Scientific Sessions of the American Heart Association, Atlanta, Georgia, USA. 1999. 